Fall 2012

\title{
Converging Trends in Investment Treaty Practice
}

Karen Halverson Cross

Follow this and additional works at: https://scholarship.law.unc.edu/ncilj

\section{Recommended Citation}

Karen H. Cross, Converging Trends in Investment Treaty Practice, 38 N.C. J. INT'L L. 151 (2012).

Available at: https://scholarship.law.unc.edu/ncilj/vol38/iss1/3

This Article is brought to you for free and open access by Carolina Law Scholarship Repository. It has been accepted for inclusion in North Carolina Journal of International Law by an authorized editor of Carolina Law Scholarship Repository. For more information, please contact law_repository@unc.edu. 
Converging Trends in Investment Treaty Practice

Cover Page Footnote

International Law; Commercial Law; Law

This article is available in North Carolina Journal of International Law: https://scholarship.law.unc.edu/ncilj/vol38/ 


\title{
Converging Trends in Investment Treaty Practice
}

\author{
Karen Halverson Crosst
}

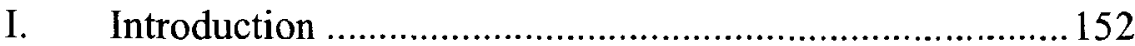

II. Evolution of U.S. BIT Practice........................................ 156

A. BIT Program Origins ............................................... 156

B. NAFTA Chapter 11 and its Effects on U.S. BIT

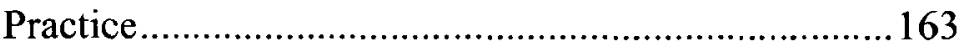

1. NAFTA Chapter 11 Claims......................................167

2. Effects on U.S. BIT Practice: MAI and TPA ........177

C. New Generation of U.S. BITs and FTAs ....................188

1. Preamble......................................................... 190

2. Limits on Indirect Expropriation. ..........................191

3. Fair and Equitable Treatment. ...............................192

4. Investor-State Arbitration.....................................193

5. Exceptions Clause.................................................... 194

D. Claims Under New Generation FTAs: CAFTA-DR and U.S.-Peru TPA ....................................................197

III. EMEs as Capital Exporters and Their Approach to BITs .207

A. EMEs as Capital Exporters .......................................207

B. BIT Practice of EME Capital Exporters ...................2210

1. Generally. .......................................................... 210

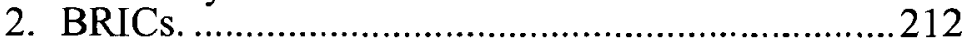

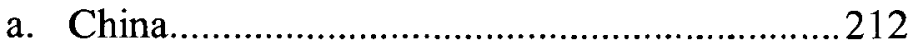

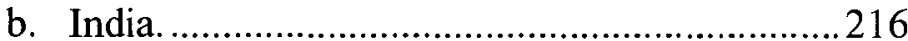

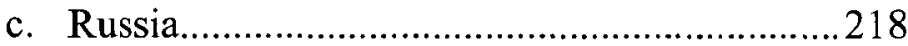

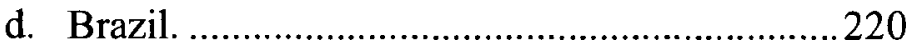

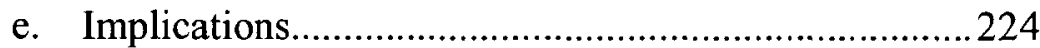

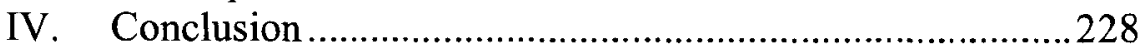

† Professor of Law, John Marshall Law School, Chicago, Illinois. I wish to thank Benjamin Liu, Ralph Folsom, and the participants of several works in progress presentations: the 2010 Annual Meeting of the Law and Society Association, the Second Biennial Global Conference of the Society of International Economic Law, and the 2011 Works in Progress Conference at the Center for the Study of Dispute Resolution of the University of Missouri School of Law, for their insights. I also thank Brent Wilson, Christopher Heery, Lyndsay Ignasiak, and reference librarians Anne Abramson and Raizel Liebler for their invaluable research assistance. Finally, I thank John Marshall Law School for supporting the research and writing of this article. 


\section{Introduction}

In 2001, William Greider of The Nation issued a scathing indictment $^{1}$ of the investment protection chapter (Chapter 11) of the North American Free Trade Agreement (NAFTA). ${ }^{2} \mathrm{He}$ characterized the investor-state arbitration mechanism of Chapter $11^{3}$ as an offshore legal venue whose "secret" proceedings are shielded from public scrutiny, and especially condemned Chapter 11 's guarantee against expropriation ${ }^{4}$ as a doctrine which "cripple[s] the regulatory state." Greider illustrated his point with the notorious Chapter 11 claim filed in 1999 against the United States by Methanex, a Canadian methanol producer. ${ }^{6}$ Methanex, seeking close to $\$ 1$ billion ${ }^{7}$ in damages, ${ }^{8}$ complained before a NAFTA tribunal that measures taken by California to protect its water supply from harmful contaminants effectively expropriated Methanex's investment in the U.S. fuel additives market. ${ }^{9}$ Greider

1 William Greider, The Right and US Trade Law: Invalidating the 20th Century, THE NATION, Oct. 15, 2001, at 21.

2 North American Free Trade Agreement, U.S.-Can.-Mex., Dec. 17, 1992, 107 Stat. 2057 (1993) [hereinafter NAFTA].

3 NAFTA Chapter 11 allows an investor that is a national or enterprise of one of the other parties to the treaty to bring a claim in arbitration against the host state for a breach of Chapter 11. See id. arts. 1115-38. See infra notes 232-243 and accompanying text for a discussion of investor-state arbitration.

4 NAFTA Chapter 11 prohibits a host state from expropriating investments unless done for a public purpose, in a non-discriminatory manner, in accordance with due process of law, and upon payment of prompt, adequate and effective compensation. This prohibition on expropriation encompasses both direct and indirect takings, including regulatory measures that are "tantamount" to an expropriation. $I d$. art. 1110.

5 Greider, supra note 1, at 21-22.

6 Methanex Corp. v. United States, 44 I.L.M. 1345 (2005) (NAFTA Ch. 11 Arb. Trib. Aug. 3, 2005) (final award), available at http://www.state.gov/documents/organization/51052.pdf.

7 Unless otherwise indicated, all dollar amounts are in U.S. dollars.

8 Methanex sought approximately $\$ 970$ million in damages, plus interest and costs. See id. at 1345 .

9 See id. at 1371. The State of California banned the use and sale of the fuel additive methyl tertiary-butyl ether (MTBE). Methanol is one component of MTBE. Id. at 1345. The ban was issued in response to the risk that the use of MTBE in gasoline posed to California's water supply, several sources of which had been shut down due to MTBE contamination. Id. at 1411. Methanex argued, among other things, that this measure was discriminatory and was "tantamount to an expropriation" of its share of the U.S. fuel additive market. $I d$. at 1371 . Although Methanex ultimately lost its claim and was even charged with all legal and administrative costs of the arbitration, see id. at 
argued that Chapter 11 , by vesting such expansive rights in the hands of foreign investors like Methanex, was like a "slow-ticking time bomb in the politics of globalization."10

Ironically, the treaty provisions that Greider's critique targets are similar to provisions in the bilateral investment treaties $(B I T s)^{11}$ that the United States had been concluding with Senegal, Cameroon, Morocco, Bangladesh, and other countries for up to a decade prior to the conclusion of NAFTA. ${ }^{12}$ It was only during the

1462-64, the mere existence of the claim has been cited by critics of Chapter 11, such as Greider, as an example of the expansive rights Chapter 11 grants to foreign investors. See also Detlav Vagts, Foreward to THE BACKLASH AGAINST INVESTMENT ARBITRATION: PERCEPTIONS AND Reality, at xxv (Waibel, Kaushal, Chung \& Balchin eds., 2010) (describing the Methanex dispute as the "most unnerving" of the Chapter 11 claims, setting off "alarm bells in Ottowa, Washington, and Mexico City"). See infra notes 131148 and accompanying text for a further discussion on Methanex.

10 Greider, supra note 1, at 21.

11 An investment treaty (typically, but not always, bilateral) is an international agreement between states whereby each signatory state undertakes to accord certain protections to investments made by nationals of the other state. BITs also usually contain a commitment by each signatory state to allow investors who are nationals of the other state to enforce BIT obligations against it through arbitration, either before the International Center for the Settlement of Investment Disputes (ICSID) or before an ad hoc tribunal. For a comprehensive discussion of the history, content, and interpretation of BITs, see Jeswald W. Salacuse, The Law of Investment Treaties (Oxford Univ. Press 2010) [hereinafter SALACUSE, LAW OF INVESTMENT TREATIES].

BITs are distinguishable from free trade agreements (FTAs) such as NAFTA. Whereas BITs only address investment protection, FTAs liberalize trade between or among the contracting states. Many FTAs contain an investment chapter, such as Chapter 11 of NAFTA. The investment chapter of an FTA is the functional equivalent of a BIT. For example, as discussed below, the provisions of the 2004 U.S. Model BIT were largely based on the investment chapters of the FTAs the United States had previously concluded with Chile and Singapore. See infra notes 185-198 and accompanying text. At times this article uses the term BIT to encompass both investment treaties and the investment chapters of FTAs.

12 The first wave of U.S. BITs was negotiated during the early 1980s: the U.S. signed its treaty with Senegal in 1983, with Morocco in 1985, and with Cameroon and Bangladesh in 1986. See United States Bilateral Investment Treaties, U.S. DEP'T OF STATE, http://www.state.gov/e/eb/ifd/bit/117402.htm (last visited Oct. 7, 2012) [hereinafter U.S. BITS]; see also KENNETH J. VANDEVELDE, U.S. INTERNATIONAL INVESTMENT AGREEMENTS 31-33 (Oxford Univ. Press 2009) [hereinafter VANDEVELDE, INVESTMENT AGREEMENTS] (discussing the history of the first wave of U.S. BIT negotiations). Although there are differences between NAFTA Chapter 11 and the early U.S. BITs, see infra note 81 , all of the treaties contain strong investor protections. In particular, like Chapter 11, the 1982 model BIT contained provisions: (i) calling for binding arbitration of disputes between the investor and the host state and (ii) 
implementation of NAFTA, when the United States began to find itself on the defending side of investment arbitration claims, that these investor protection provisions became controversial. ${ }^{13}$ Additionally, the politics of globalization to which Greider refers ${ }^{14}$ eventually influenced the substance of a new generation of BITs, moderating some of the more controversial provisions.

The political philosopher John Rawls famously advocated that fairness is central to justice, ${ }^{15}$ and fair institutions are those that derive from the "original position," an imaginary state where hypothetical rulemakers have no knowledge of their vested interests and of how a chosen rule might affect them-what Rawls referred to as operating under a "veil of ignorance."16 Traditionally, the vested interests of states concluding BITs fell into two categories: those on the side of capital-exporting states, with an interest in adopting strong protections for foreign investors; and those on the side of capital-importing states, with an interest not only in attracting foreign investment but also in attempting to preserve host country sovereignty and authority to promote the public interest. ${ }^{17}$ For example, during the early years of U.S. BIT practice, the government concluded treaties with weaker, capital-importing states that contained unambiguously

guaranteeing against host state measures that, directly or indirectly, are "tantamount to an expropriation." See VAndeVELdE, InVestment AgreEments, supra, at Appendix A, arts. 3(1), 7. Under the 1982 model BIT, the right to bring a claim to investor-state arbitration was subject to any dispute settlement provision agreed to between the investor and the host state; however, U.S. negotiators soon revised the text to place the election of remedies within the sole discretion of the investor. Id. at 579-80.

13 See VANDEVElde, INVESTMENT AGREEMENTS, supra note 12, at 64-65.

14 See supra text accompanying note 10.

15 See Amartya Sen, The Idea of Justice 53 (2009) (referring to Rawls's "foundational idea that justice has to be seen in terms of the demands of fairness").

16 JOHN RAWLS, A ThEORY OF Justice 118-19 (rev. ed. 1999). The idea behind the original position is to use pure procedural justice to ensure fairness. The veil of ignorance "nullif[ies] the effects of specific contingencies which put men at odds and tempt them to exploit social and natural circumstances to their own advantage." Id. at 118. Behind the veil of ignorance, a party is unaware of his class position, social status, natural abilities, or the particular circumstances of his own society, including its economic or political situation. See id. Amartya Sen describes Rawls's conception of the original position as "an imagined situation of primordial equality, when the parties involved have no knowledge of their personal identities, or their respective vested interests, within the group as a whole." SEN, supra note 15, at 54.

17 See Salacuse, Law of Investment TREaties, supra note 11, at 91-96. 
robust pro-investor protections. ${ }^{18}$

Over the past decade or so, however, the line between capitalexporting and capital-importing state has increasingly blurred, and the calculus for states negotiating BITs has become less certain. ${ }^{19}$ To an extent, therefore, states are moving closer to the "original position." ${ }^{\text {,20 }}$ The event that first situated the United States as a host-country state under a BIT was the conclusion of NAFTA Chapter $11 .^{21}$ The experience of the United States as a respondent to claims brought to arbitration by investors such as Methanex significantly affected the development of a new generation of U.S. BITs that better balance the interests of host states against those of foreign investors. ${ }^{22}$ Similarly, as emerging market economies (EMEs) $^{23}$ such as India and China have become significant exporters of capital, these countries have increasingly

18 See infra Part II.A.

19 See J.E. Alvarez, The Evolving BIT, 7(1) TRANSNAT'L DISP. MgmT., Apr. 2010, at 8-9, available at http://www.law.nyu.edu/ecm_dlv1/groups/public/@nyu_law_website faculty_faculty_profiles_jalvarez/documents/documents/ecm_pro_065335.pdf.

20 See Rawls, supra note 16, at 15-19 (discussing Rawls's theory of the "original position").

21 See infra notes 75-76 and accompanying text.

22 See infra Part II.B. Others have made the argument that the U.S. experience under NAFTA Chapter 11 affected its subsequent BIT practice. See Alvarez, supra note 19, at 8-9; VANDEVELDE, INVESTMENT AGREEMENTS, supra note 12, at 64-65, 70-74; David A. Gantz, The Evolution of FTA Investment Provisions: From NAFTA to the United States-Chile Free Trade Agreement, 19 AM. U. INT'L L. REv. 679, 685-91 (2004) [hereinafter Gantz, Evolution of FTA Investment Provisions]; Gilbert Gagné \& Frédéric Morin, The Evolving American Policy on Investment Protection: Evidence from Recent FTAs and the 2004 Model BIT, 9 J. INT'L ECON. L. 357, 360-67 (2006).

Although this article focuses on the effect of NAFTA Chapter 11 on U.S. practice, the experience of investor-state arbitration under NAFTA Chapter 11 affected Canadian BIT practice as well. See generally Céline Lévesque, Influences on the Canadian FIPA Model and the US Model BIT: NAFTA Chapter 11 and Beyond, 44 CAN. Y.B. INT'L L. 249 (2006) (discussing influences, including experiences under NAFTA Chapter 11, on Canada's 2004 model foreign investment protection and promotion agreement and on the U.S. 2004 model BIT).

23 The term "emerging market economies" (EMEs) refers to all economies not classified as developed economies by the United Nations Conference on Trade and Development (UNCTAD). See Persephone Economou \& Karl P. Sauvant, From the FDI Triad to Multiple FDI Poles?, Colum. FDI PerspeCtives, July 18, 2011, http://www.vcc.columbia.edu/content/fdi-triad-multiple-fdi-poles. A list of developed economies can be found at UNCTAD, UNCTAD HANDBOOK OF STATISTICS 2010, at xiv, U.N. Doc. TD/STAT.35, U.N. Sales No. B.10.TI.D.1 (2010). 
implemented BITs that protect their investors abroad. ${ }^{24}$ Indian automaker Tata Motors' 2008 acquisition of the venerable British automaker Jaguar ${ }^{25}$ vividly illustrates how the line between capital-exporting and capital-importing states has blurred. While certain developing country leaders denounce BITs and investment arbitration-witness the withdrawals of Bolivia, Ecuador, and Venezuela from ICSID ${ }^{26}$ - developing countries with the largest amounts of outward foreign direct investment (FDI), such as India and China, continue to conclude BITs and FTAs with investment chapters. ${ }^{27}$ Although Brazil has not yet ratified a single BIT, ${ }^{28}$ its emergent status as a capital exporting country should lead to a greater acceptance of BITs and investment arbitration in Brazil over time.

This article examines this convergence in BIT practice. It focuses on (i) the impact of NAFTA Chapter 11 on the development of the current generation of U.S. BITs and FTAs and (ii) the changing dynamics of FDI and investment protection in EMEs. It suggests that these converging trends, a function of states operating behind a "veil of ignorance," 29 are having and should continue to have a moderating influence on the content of BITs. Part II outlines the evolution of U.S. BIT practice from its origins to the current generation of U.S. BITs and FTAs. Part III discusses the recent emergence of EMEs as significant exporters of FDI, the effects of this trend on these countries' BIT practices, and the policy implications of these developments. Part IV concludes.

\section{Evolution of U.S. BIT Practice}

\section{A. BIT Program Origins}

Although the earliest BITs date back to $1959,{ }^{30}$ the United

24 See infra Part lII.B.

25 See James Surowiecki, The Tata Invasion, THE NEW YORKER, Jan. 28, 2008, at 27.

26 See infra notes $70-71$ and accompanying text.

27 See infra Part III.B.

28 See infra notes 382-406 and accompanying text.

29 See generally RAWLS, supra notes 14-15 and accompanying text.

30 The first BITs were concluded by Germany with Pakistan and the Dominican Republic. See Jeswald W. Salacuse, The Emerging Global Regime for Investment, 51 
States only began developing its own BIT program in the 1980s, and it was not until 1986 that Congress ratified the first wave of treaties. $^{31}$ Although the titles and preambles of BITs generally suggest that the purpose of such treaties is the mutual promotion and protection of investments, ${ }^{32}$ in fact the overriding U.S. policy behind developing the BIT program was to protect existing investments made by United States nationals abroad. ${ }^{33}$ Since customary international law was inadequate to provide meaningful protection to foreign investors, ${ }^{34}$ the United States and other capital-exporting countries concluded BITs with developing countries $^{35}$ in order to create binding international commitments

HARV. INT'L L.J. 427, 433 (2010) [hereinafter Salacuse, Emerging Global Regime].

31 See VANDEVELDE, InVESTMENT AGREEMENTS, supra note 12, at 30. Vandevelde describes the U.S. Department of State's Legal Adviser's Office as a "driving force" behind the development of the U.S. program. Id. at 31-32.

32 See Salacuse, Law of INVESTMEnt Treaties, supra note 11, at 109.

33 See VANDEVELDE, INVESTMENT AgREEMENTS, supra note 12, at 31 (describing U.S. policy as "neither to encourage nor to discourage investment overseas, but rather to ensure stable and transparent treatment of such investment when it occurred").

34 See Jeswald W. Salacuse \& Nicholas P. Sullivan, Do BITs Really Work?: An Evaluation of Bilateral Investment Treaties and Their Grand Bargain, 46 HARV. INT'L L.J. 67, 68-70 (2005). Salacuse and Sullivan identify four shortcomings of customary international law relating to investment protection: (i) the nonexistence of standards on certain issues of concern to foreign investors, such as the right of an investor to effect monetary transfers from a host country; (ii) the vagueness and inconsistency of certain standards, such as the amount of compensation due to an investor in the event of expropriation; (iii) the controversy surrounding issues such as expropriation; and (iv) the lack of an effective enforcement mechanism for investors to pursue claims against host countries. Id.

35 Prior to the United States' signing of NAFTA in December 1992, it had concluded BITs with twenty-two countries, all either developing countries or formerly socialist economies. U.S. BITs, supra note 12 (listing as countries with pre-existing BITs: Argentina, Armenia, Bangladesh, Bulgaria, Cameroon, Democratic Republic of the Congo, Republic of the Congo, Czech Republic, Egypt, Grenada, Haiti, Kazakhstan, Morocco, Panama, Poland, Romania, Russia, Senegal, Slovakia, Sri Lanka, Tunisia, and Turkey).

The United States also concluded FTAs with Israel and Canada during the 1980s. However, the Israel-U.S. FTA does not include an investment chapter. See Agreement on the Establishment of a Free Trade Area between the Government of Israel and the Government of the United States of America, U.S.-Isr., Apr. 22, 1985, 24 I.L.M. 647, available at http://tcc.export.gov/Trade_Agreements/All_Trade_Agreements/ exp_005439.asp. Although the Canada-U.S. FTA includes an investment chapter, the chapter does not grant foreign investors the right to bring investment arbitration claims against the host state. See Canada-United States: Free-Trade Agreement, U.S.-Can., 
where customary international law standards were inconclusive or non-existent. Professor Jeswald Salacuse argues that, collectively, BITs can be seen as an undertaking by capital-exporting states to create an international regime for the protection of investment. ${ }^{36}$

To this end, BITs concluded during this period typically included the following investment protections ${ }^{37}$ (examples are based on the text of the U.S.-Argentina BIT, ${ }^{38}$ which was concluded in 1991):

- Non-discriminatory treatment. Requires the host state to accord investments, ${ }^{39}$ and activities associated with investments, the better of national treatment and mostfavored nation treatment (subject to enumerated exceptions listed in the treaty).$^{40}$

- Fair and equitable treatment. Requires the host state to accord investments "fair and equitable treatment" and "full protection and security," in no case "less than that required by international law." $"$ As discussed

Dec. 22, 1987-Jan. 2, 1989, 27 I.L.M. 281.

36 See Salacuse, Emerging Global Regime, supra note 30, at 436-37. Salacuse borrows from international relations theory to argue that the existing body of BITs constitutes a regime, defined as "principles, norms, rules, and decision-making procedures around which actors' expectations converge in a given area of international relations." Id at 431 (quoting Stephen D. Krasner, Structural Causes and Regime Consequences: Regimes as Intervening Variables in POWER, THE STATE, AND SOVEREIGNTY: ESSAYS ON INTERNATIONAL RELATIONS 113, 113 (Stephen D. Krasner ed., 2009)).

37 For a comprehensive discussion of the specific protections provided in the early U.S. BITs, see, for example, VANDEVELDE, INVESTMENT AGREEMENTS, supra note 12, at 31-41.

38 Treaty Between the United States of America and the Argentine Republic Concerning the Reciprocal Encouragement and Protection of Investment, U.S.-Arg., Nov. 14, 1991, 31 I.L.M. 124 [hereinafter U.S.-Arg. BIT].

39 The term "investment" refers to investments owned and controlled by a national of a party to the treaty, and is broadly defined as including, among other things, "any right conferred by law or contract," intellectual property rights, and "a claim to money or a claim to performance having economic value and directly related to an investment." Id. art. $\mathrm{l}(1)$.

40 Id. art. II(1). National treatment refers to an obligation of the host state to treat foreign investments no less favorably than it treats its own nationals or companies, whereas most-favored nation treatment refers to an obligation of the host state to treat investments from the other party no less favorably than it treats investments from any third country. $I d$.

41 Id. art. II(2). 
below ${ }^{42}$ some tribunals have interpreted this language as setting a customary international law floor on the fair and equitable treatment standard and establishing an independent, higher standard of treatment to be met. $^{43}$

- "Prompt, adequate and effective compensation" in the event of expropriation. ${ }^{44}$ Prohibits the host state from expropriating investments unless done for a public purpose, in a non-discriminatory manner, in accordance with due process of law, and upon payment of "prompt, adequate and effective compensation." ${ }^{\text {"45 }}$ The prohibition on expropriation encompasses both direct and indirect takings, including regulatory measures that are "tantamount" to an expropriation. ${ }^{46}$

- Free transferability of payments. Requires the host state to permit all currency transfers, including returns on investment, principal and interest payments on a loan, proceeds from the liquidation of an investment, and other such payments, to be made freely and without delay, in a "freely usable" currency (such as the U.S. dollar or the euro). ${ }^{47}$ This obligation is subject to very limited exceptions, such as income tax withholding requirements, and protecting creditors' rights in the host country. ${ }^{48}$

- Prohibition on performance requirements as a condition to investment. Prohibits the host state from conditioning investment approval on performance requirements, such as achieving minimum export levels or requiring that goods and services be sourced locally. ${ }^{49}$

42 See infra notes 109-1 14 and accompanying text (discussing Metalclad).

43 As discussed below, the 2004 U.S. Model BIT appears to narrow the fair and equitable treatment standard. See infra notes 194-201 and accompanying text.

44 U.S.-Arg. BIT, supra note 38, art. IV(1).

45 Id

46 Id.

47 Id. art. V.

$48 \mathrm{Id}$.

49 Id. art. II(5). 
- Investor right to arbitrate disputes with the host state. Allows an investor who is a national or entity of the other party to the treaty to bring to arbitration (either to ICSID $^{50}$ or to ad hoc arbitration) any investment dispute with the host state relating to (i) an investment agreement with or investment authorization by the host state or (ii) a breach by the host state of the BIT. ${ }^{51}$ This provision is the most important investor protection in a $\mathrm{BIT}$, as it accords investors a private right of action against the host state, a right that is unavailable to private parties in other areas of international law. ${ }^{52}$

The preceding discussion highlights what the United States, as a capital-exporting country, stood to gain from concluding BITs. Less evident is why capital-importing countries such as Argentina,

50 The International Centre for Settlement of Investment Dispute (ICSID) was established by the World Bank during the 1960s out of a belief that the existence of a neutral tribunal to resolve disputes would mitigate political risk, thereby encouraging foreign investment in developing countries. It is a neutral arbitral body in the sense that it is detached from any system of national law, but its awards are directly enforceable in the states that are party to the ICSID Convention. See LUCY REED, JAN PAULSSON \& Nigel Blackaby, Guide to ICSID ARBITRation 1, 5 (2003). ICSID's jurisdiction is limited to resolving investment disputes between a host state that is a party to the ICSID Convention and a foreign investor, where the parties have consented in writing to submit the dispute to ICSID. Convention on the Settlement of Investment Disputes between States and Nationals of Other States art. 25(1), Mar. 18, 1965, 17 U.S.T. 1270, 575 U.N.T.S. 159 [hereinafter ICSID Convention]. For more information on the ICSID, see CHRISTOPH H. SCHREUER, THE ICSID CONVENTION: A COMMENTARY (2001).

51 See U.S.-Arg. BIT, supra note 38, art. VII. If it is not possible to settle the dispute amicably, and if six months have elapsed from the time the dispute arose, the investor may submit the dispute to the host state's domestic courts for resolution, following any dispute settlement mechanism specified in the contract, if any, with the host state or utilizing the investor-state arbitration mechanism provided for in the BIT. Id. art. VII(2)-(3). The arbitration provision of the BIT is treated as an offer to arbitrate by the host state, which the investor accepts when it submits a request for arbitration. REED, PAULSSON \& BLACKABY, supra note 50, at 35.

52 For example, compare this provision with the rules of the World Trade Organization (WTO). See Understanding on Rules and Procedures Governing the Settlement of Disputes arts. 4.3, 4.7, Apr. 15, 1994, Marrakesh Agreement Establishing the World Trade Organization, Annex 2, 1869 U.N.T.S. 401 (referring to a WTO member's right to request establishment of a panel if consultations are not successful). Only WTO member states have standing to bring a claim to WTO dispute settlement. Id.; see also Bernard M. Hoekman \& Michel M. KosteCKI, THE Political ECONOMY of THE World Trading SYStem 87 (Oxford Univ. Press, 2d ed. 2001) ("Only governments have legal standing to bring cases to the WTO."). 
Haiti, or Bangladesh, would conclude BITs with the United States. Several explanations have been offered. It is commonly acknowledged that capital-importing states enter into BITs in order to promote foreign investment. ${ }^{53}$ In a 1998 article, Andrew Guzman identified the paradox that many developing countries in the past collectively fought against strict customary international law standards on expropriation, but, individually, have undertaken strong investor-protection commitments by concluding BITs. ${ }^{54} \mathrm{He}$ explained this paradox by suggesting that developing countries face a "prisoners' dilemma" in which, by concluding BITs, an individual developing country "defects" from the group in order to make itself a more attractive target of foreign investment in comparison with other developing countries. ${ }^{55}$ Jeswald Salacuse and Nicholas Sullivan have characterized a BIT between a capital-

53 See Andrew T. Guzman, Why LDCs Sign Treaties That Hurt Them: Explaining the Popularity of Bilateral Investment Treaties, 38 VA. J. INT'L L. 639, 666-71 (1998); Salacuse \& Sullivan, supra note 34 , at 77 ; cf. Roberto Echandi, What Do Developing Countries Expect from the International Investment Regime, in THE EvolvING InTERNATIONAL INVESTMENT REGIME: EXPECTATIONS, REALITIES, OPTIONS 5-6 (José E. Alvarez \& Karl P. Sauvant eds., 2011) (acknowledging that most literature analyzes the expectations of developing countries regarding BITs in terms of the ability of these countries to attract foreign investment, but observing that the current situation is more complex).

54 Guzman, supra note 53, at 642.

55 Id at 666-67. Guzman argues that, by making credible commitments to potential foreign investors, developing countries that conclude BITs can attract greater amounts of investment, albeit at the expense of other developing countries. Id. at 66970.

Despite the accepted wisdom that capital-importing countries enter into BITs in order to attract capital, it is unclear whether BITs are effective to this end. Empirical studies of the effect of BITs on foreign investment are inconclusive. See Kevin P. Gallagher \& Melissa B.L. Birch, Do Investment Agreements Attract Investment? Evidence from Latin America, in THE EFFECT OF TREATIES ON FOREIGN DiRECT Investment: Bilateral Investment Treaties, Double Taxation Treaties, and InVESTMENT Flows 308-09 (Karl P. Sauvant \& Lisa E. Sachs eds., 2009) [hereinafter THE EFFECT OF TREATIES] (finding no evidence that signing investment agreements with the United States results in greater investment); U.N. CONFERENCE ON TRADE AND DeVELOPMENT, The Impact on Foreign Direct Investment of BITs in THE EFFECT OF TREATIES, supra, at 347-48 (concluding that BITs "appear to play a minor and secondary role in influencing FDI flows"); cf. Jason Yackee, Do BITs Really Work? Revisiting the Empirical Link Between Investment Treaties and Foreign Direct Investment, in THE EFFECT OF TREATIES, supra, at 391 (questioning whether large- $n$ statistical studies of aggregate FDI flows are the best means of empirically addressing the question of the effect of BITs on FDI). 
exporting and capital-importing country as a "grand bargain," a promise by the host state to protect the capital invested in exchange for the future prospect of additional capital. ${ }^{56}$

At least throughout the $1980 \mathrm{~s}$, a BIT concluded with the United States looked more like a contract of adhesion than a "grand bargain." 57 According to accounts of former State Department attorney-advisers, at that time the United States presented BITs to developing countries on a take-it-or-leave-it basis. ${ }^{58}$ With evident sarcasm, Professor José Alvarez describes his days as a State Department lawyer during the 1980s as the "glory days-when BITs were BITs and real tough BIT negotiators were negotiating strong, testosterone fuelledtreaties." 59 He suggested that a BIT's reference to "reciprocal" protection of investments was "something of a fraud," 60 and described as ludicrous the notion that BIT negotiations between the United States and its developing-country counterparts were conducted as if between sovereign equals. ${ }^{61}$ Professor Kenneth Vandevelde similarly refers to U.S. negotiations during that time as uncompromising. ${ }^{62} \quad$ This approach stemmed from the government's desire to build a uniform body of state practice in international law that was supportive of foreign investment. ${ }^{63}$ Accordingly, the U.S. position was "generally intransigent," which resulted in a relatively small number of BITs being concluded with the United States during the 1980s. ${ }^{64}$ During the 1990s, however,

56 Salacuse \& Sullivan, supra note 34 , at 77 . In a recent article, Salacuse identifies other possible motivations for capital-importing countries to sign BITs: relationship building; economic liberalization; encouraging domestic investment; and strengthening rule of law within the country. Salacuse, Emerging Global Regime, supra note 30, at 440-41.

57 See Alvarez, supra note 19, at 5 (explaining the United States' unwillingness to compromise regarding to the provisions of BITs in the 1980s).

58 See id.

59 See id. at 3.

60 Id.

61 Specifically, Alvarez stated, "[t]he idea that the United States-Grenada BIT negotiations - conducted three years after the United States invaded that island and toppled its government to rescue some U.S. medical students - were conducted among 'sovereign equals' seems worthy of a Monty Python skit." Id. at 5 .

62 VANDEVELDE, INVESTMENT AGREEMENTS, supra note 12, at 32.

63 See id.

64 Id. 
notwithstanding the imbalance of bargaining power that continued to exist between BIT parties, the number of BITs concluded worldwide more than quadrupled, from 446 concluded BITs in 1990 to 1941 BITs one decade later. ${ }^{65}$

To summarize, during the early years of the U.S. BIT program, the United States signed treaties with relatively poor countries whose domestic companies were unlikely to export capital to the United States. Whereas the overriding goal of the U.S. BIT program was to protect foreign investment, the objective of the developing countries that concluded BITs with the United States was generally to attract foreign investment. However, as discussed below, sovereign objectives behind concluding BITs are significantly more complex today than they were twenty or so years ago.

\section{B. NAFTA Chapter 11 and its Effects on U.S. BIT Practice}

The popularity of BITs that prevailed during much of the 1990s eventually gave way to a backlash. ${ }^{66}$ In Latin America, this backlash was triggered in part by Argentina's devastating financial crisis. Argentina concluded dozens of BITs during the $1990 \mathrm{~s} .{ }^{67}$ Consequently, in the aftermath of the crisis, the government found itself before ICSID and other arbitration tribunals, defending dozens of claims brought by investors complaining of the measures that Argentina took in response to the crisis. ${ }^{68}$ According to one observer, if Argentina were presented with these same BITs today, "it is nearly certain" that it would not enter into

65 See Quantitative Data on Bilateral Investment Treaties and Double Taxation Treaties, UNITED NATIONS CONFERENCE ON TRADE AND DEVELOPMENT, http://www.unctad.org/Templates/WebFlyer.asp?intItemID=3150\&lang=1 (last visited Oct. 7, 2012) [hereinafter UNCTAD, Quantitative Data].

66 Oscar M. Garibaldi, Carlos Calvo Redivinus: The Rediscovery of the Calvo Doctrine in the Era of Investment Treaties, 3(5) TRANSNAT'L DisP. MGMT. 1, 24 (2006) (providing a timeline of the backlash of traditional BITs in Latin America).

67 During the 1990s, Argentina concluded fifty-three BITs. See Organization of American States Foreign Trade Information System, Information on Argentina: Bilateral Investment Treaties, ORGANIZATION OF AMERICAN STATES http://www.sice.oas.org/ctyindex/ARG/ARGBITS_e.asp (last visited Oct. 7, 2012).

68 Of the 390 known investment treaty arbitration claims, 51 have been against Argentina. See UNCTAD, Latest Developments in Investor-State Dispute Settlement, IIA Issues NOTE No. 1 (Mar. 2011), available at http://www.unctad.org/en/docs/webdiaeia20113_en.pdf. 
them. ${ }^{69}$ Elsewhere in Latin America, populist leaders made dramatic gestures against investment claims, or the threat of such claims, in their respective countries. In 2007, the Morales government provided notice to the World Bank that Bolivia would be the first state to withdraw from the ICSID Convention. ${ }^{70}$ Ecuador followed suit in 2009." In 2008, Venezuela gave notice that it would terminate a Venezuela-Netherlands BIT that had been frequently relied upon by multinationals in structuring Venezuelan investments, ${ }^{72}$ and in 2012 , Venezuela announced that

69 Garibaldi, supra note 66 , at 3 . Garibaldi argues that the Calvo Doctrine is being rediscovered in Latin America as an intellectually respectable and traditionally consistent political justification for opposing BITs. The Calvo Doctrine, attributed to Argentine jurist Carlos Calvo, is based on the premise that foreign investors must be treated no more favorably than domestic citizens, and opposes intervention by a foreign government to aid one of its investors as an impermissible interference in the internal affairs of the host state. Id. at 6-8. Garibaldi refers to the Calvo Doctrine as representing the "obverse" of the merits of BITs. Id. at 4.

70 See ICSID Convention, supra note 50; see also Damon Vis-Dunbar, Luke Eric Peterson \& Fernando Cabrera Diaz, Bolivia Notifies World Bank of Withdrawal from ICSID, Pursues BIT Revisions, IISD INV. TREATY NEws (May 9, 2007) http://bilaterals.org/spip.php?article8221. Bolivia's withdrawal may have been triggered by threats of arbitration by foreign investors in response to moves by the government to nationalize certain sectors of the economy. See id. Memories of the notorious Aguas del Tunari dispute, a controversial ICSID arbitration claim brought by the water conglomerate Bechtel against Bolivia, may have also played a role. For a history of that dispute, see, for example, William Finnegan, Leasing the Rain, THE NEW YORKER, Apr. 8,2002 , at 43 .

71 See Luke Eric Peterson, Ecuador Becomes Second State to Exit ICSID, INV. ARB. REP. (July 17, 2009), http://www.iareporter.com/articles/EcuadorExit (last visited Oct. 7, 2012) (subscription required). In addition to at least six investment treaty claims brought against Ecuador before non-ICSID tribunals, thirteen investor-state claims have been brought against Ecuador through ICSID. Id. In September 2009, two months after the Correa regime provided its notice of withdrawal from ICSID, Chevron commenced investor-state arbitration proceedings against Ecuador under the Ecuador-U.S. BIT, alleging improprieties in environmental litigation conducted against it in Ecuador courts. For background to the Lago Agrio litigation and Chevron's request for investment arbitration, see Ecuador v. Chevron Corp., 638 F.3d 384, 388-91 (2d Cir. 2011).

72 See Luke Eric Peterson, Venezuela Surprises the Netherlands with Termination Notice for BIT, INV. ARB. REP. (May 16, 2008), http://www.iareporter.com/articles/20091001_93 (last visited Oct. 7, 2012) (subscription required). Numerous multinational oil companies have structured their Venezuelan investments using Dutch-registered companies, and several have filed expropriation claims in arbitration against Venezuela in reliance on the Venezuela-Netherlands BIT. Id. 
it would be withdrawing from ICSID. ${ }^{73}$ Among other factors, the process of defending against a growing number of investment arbitration claims prompted these governments to reevaluate the relative costs and benefits of BITs. ${ }^{74}$

Although less extreme, a re-evaluation has taken place in the United States as well. ${ }^{75}$ The event that precipitated this reevaluation was the implementation of NAFTA Chapter 11. For the first time, during the mid-to-late 1990s, the United States experienced investment arbitration from the other side of the bargain, as a host state to foreign investment from Canada. ${ }^{76}$ As of January 1994, when NAFTA went into effect, the United States was by far Canada's largest foreign direct investor (and still is). ${ }^{77}$ Similarly, during the same period, Canadian companies were the second-highest exporters of FDI to the United States. ${ }^{78}$ As a

73 Venezuela Foreign Ministry Says It Has Filed to Depart World Arbitration Panel, LATIN AM. HERALD TRIB. (Jan. 25, 2012), http://www. laht.com/article.asp?Categoryld=10717\&ArticleId=466009.

74 See, e.g., Peterson, supra note 72 (referencing multiple instances of threatened arbitration as a possible reason for Venezuela's termination notice).

75 See Alvarez, supra note 19 (describing the cautious attitude adopted by the United States toward BITs after NAFTA).

76 Similarly, Canada found itself, for the first time, defending against investment claims brought against it by U.S. investors. See S.D. Myers, Inc. v. Gov't of Canada, 401 I.L.M. 1408 (NAFTA Arb. Trib. Nov. 13, 2000) (partial award under NAFTA/UNCITRAL), available at http://ita.law.uvic.ca/documents/SDMeyers1stPartialAward.pdf.

77 As of the end of 1993, just before NAFTA went into effect, stocks of FDI from the United States into Canada were at 90.6 billion Canadian dollars, well over half of the total FDI stocks for that year. See Foreign Direct Investments (Stocks) in Canada, Foreign AFF. \& INT'L TRADE CAN. (Aug. 2012), http://www.international.gc.ca/economist-economiste/assets/pdfs/Data/investmentsinvestissements/FDI_by_Country/FDI_stocks-Inward_by_Country-ENG.pdf. As of April 2011, the United States remained Canada's largest foreign investor. Id.

78 Canada is currently the eighth largest exporter of FDI into the U.S. See David Payne \& Fenwick Yu, Foreign Direct Investment in the United States, U.S. DEPT. OF COM. ECON. \& STAT., Admin. Issue Brief \#02-11, fig. 6 (June 2011), available at http://www.esa.doc.gov/sites/default/files/news/documents/fdiesaissuebriefno2061411 fin al.pdf. However, as of the end of 1993, just before NAFTA went into effect, Canada was ranked second. See Mahnaz Fahim-Nader, U.S. Business Enterprises Acquired or Established by Foreign Direct Investors in 1993, SURVEY OF CURRENT BUSINESS 50, 56 tbl. $5.2 \quad$ (May 1994), available at http://www.bea.gov/scb/pdf/internat/fdinvest/1994/0594ii.pdf. Investment outlays by Canadian companies into U.S. affiliates for that year stood at just under $\$ 4$ billion, the second highest level by country after the U.K. Id. 
former attorney-adviser to the State Department observed, the United States "took a very big step into the unknown" when it concluded NAFTA Chapter $11 .^{79}$ Although the United States had concluded numerous BITs by the time it signed NAFTA, it had never done so with a state that had so much investment in the United States. ${ }^{80}$

As previously noted, NAFTA Chapter 11 contains investment protection provisions that parallel those contained in the BITs previously concluded by the United States. Although there are differences in the specific content of some of the provisions, ${ }^{81}$ each of the investment protection commitments described above ${ }^{82}$ with respect to BITs can also be found in NAFTA Chapter $11 .^{83}$ In other words, by concluding NAFTA, the United States, for the first time, agreed to grant to a significant capital-exporting state both commitments to protect investments and standing to foreign investors to bring arbitration claims against the United States for breach of those commitments. Although the U.S. negotiators of NAFTA may not have fully appreciated the consequences of this undertaking, ${ }^{84}$ over time they would. Since 1994, when NAFTA

79 Mark Clodfelter, U.S. State Department Participation in International Economic Dispute Resolution, 42 S. TEX. L. REv. 1273, 1283 (2001), quoted in Gantz, Evolution of FTA Investment Provision, supra note 22, at 685.

$80 \mathrm{Id}$.

81 Examples of the changes found in NAFTA Chapter 11 (as compared to the U.S.Argentina BIT provisions described above) include: (i) the addition of an article acknowledging that the parties should not encourage investment by relaxing environmental, health or safety measures [art. 1114]; (ii) more detailed commitments regarding the prohibition on performance requirements, but also a carve-out that tracks some of the exceptions to the General Agreement on Tariffs and Trade (GATT) relating to health and safety measures, environmental measures, and measures to ensure compliance with domestic law [art. 1106(6)]; and (iii) a more detailed investor-state arbitration provision that among other things requires the investor to provide ninety days advance notice of investment claims [art. 1119] and imposes a three year limitation period on investor claims [art. 1116(2)]. NAFTA, supra note 2, arts. 1114, 1106(6), $1116(2), 1119$.

82 See supra notes 37-52 and accompanying text.

83 See NAFTA, supra note 2, arts. 1102-04 (non-discriminatory treatment), art. 1110 (expropriation), art. 1102 (transfers), art. 1106 (performance requirements), arts. 1115-38 (investor-state arbitration).

84 Vandevelde writes that early U.S. BIT negotiations were conducted with little regard to the possibility that investor claims might be brought against the United States:

U.S. policy makers during the initial formulation of the model negotiating text 
went into effect, investors have filed dozens of arbitration claims against Mexico, Canada, and the United States, alleging violations of Chapter 11. ${ }^{85}$ These claims, including the Methanex claim described in Part $\mathrm{I}$, have attracted notoriety and some criticism, and eventually were instrumental in shaping subsequent U.S. BIT practice. ${ }^{86}$ Several of the claims that have most notably affected attitudes in the United States towards BITs and investment arbitration are discussed below. ${ }^{87}$

\section{NAFTA Chapter 11 Claims}

Two of the first Chapter 11 claims, Ethyl Corp. v. Government of Canada ${ }^{88}$ and Metalclad v. United Mexican States, ${ }^{89}$ involved U.S. claimants but nonetheless attracted the attention of environmental and other public interest organizations concerned about corporate power to challenge environment- and healthrelated regulation. ${ }^{90}$ In Ethyl, a U.S.-based investor and producer of methylcyclopentadienyl manganese tricarbonyl (MMT), challenged a Canadian law, the Manganese-based Fuel Additives Act, that banned the inter-provincial trade in or transport of MMT. ${ }^{91}$ MMT is a fuel additive that contains manganese, a

and the first wave of negotiations rarely discussed the extent to which BIT provisions might hinder U.S. treatment of foreign investment. In those days, BIT policy assumed a world in which investment flows were outward from the United States.

VANDEVELDE, INVESTMENT AGREEMENTS, supra note 12, at 50 .

85 According to the State Department website, to date, forty-three investment arbitration claims have been filed against the NAFTA parties under Chapter 11 . Seventeen of these claims were filed against the United States, all but one involving Canadian claimants. See NAFTA Investor-State Arbitrations, U.S. DeP'T OF STATE, http://www.state.gov/s/l/c3439.htm (last visited Oct 8, 2012).

86 See, e.g., Greider, supra note 1.

87 See infra notes 259-310 and accompanying text.

88 Ethyl Corp. v. Gov't of Can., 38 I.L.M. 708 (NAFTA Chap. 11 Trib. June 24, 1998) (award on jurisdiction under NAFTA/UNCITRAL).

89 Metalclad Corp. v. United Mexican States, ICSID Case No. ARB(AF)/97/1, Award (Aug. 30, 2000), 5 ICSID Rep. 212 (2002).

90 Pub. Citizen \& Friends of the Earth, NAFTA Chapter 11 InVESTOR-TOState Cases: Bankrupting Democracy 3-4, 9-10, 13-14 (Public Citizen's Global Trade Watch ed., 2001), available at http:/www.citizen.org/documents/ACF186.PDF.

91 Ethyl Corp., 38 I.L.M. at 710, $\uparrow 5$. 
neurotoxin banned for use in gasoline in the United States. ${ }^{92}$ Ethyl argued that the Act was discriminatory, that it effectively expropriated its Canadian investment, and that it violated Chapter 11 's prohibition on performance requirements. ${ }^{93}$ Ethyl filed a notice of intent to submit an arbitral claim in September 1996, when Canada's Parliament was still deliberating the proposed legislation (the Act entered into force in June 1997). ${ }^{94}$ When the arbitral tribunal issued an award upholding its jurisdiction to hear the dispute, the Canadian government settled Ethyl's claim by agreeing to pay Ethyl $\$ 13$ million and to withdraw the Act. ${ }^{95}$ Ethyl was particularly significant because of its timing: observers were troubled by what looked like a coercive move by a corporate investor to influence the legislative process by threatening to bring a Chapter 11 claim. ${ }^{96}$ The timing of the Ethyl dispute was also significant because the claim and ensuing settlement occurred while the United States, Canada, and other developed countries were in negotiations to conclude the Multilateral Agreement on Investment (MAI), negotiations that unraveled in December 1998. ${ }^{97}$ The Ethyl dispute has been described as "pivotal" in galvanizing non-governmental organizations' (NGOs) opposition to the MAI. ${ }^{98}$

92 PUB. Citizen \& FriEndS OF THE EARTH, supra note 90, at 8. In 1995, Ethyl won a lawsuit against the U.S. Environmental Protection Agency, which subsequently lifted its restrictions on MMT. $I d$. at n.34.

93 See Ethyl Corp., 38 I.L.M. at 711 , 17.

94 See $i d$. I 21. Although NAFTA requires investors to provide at least 90 days' notice before filing a claim, NAFTA, supra note 2, art. 1119, Ethyl provided seven months' notice. Ethyl Corp., 38 I.L.M. at 714, 121.

95 David R. Haigh, Chapter 11 - Private Party vs. Governments, Investor-State Dispute Settlement: Frankenstein or Safety Valve?, 26 CAN.-U.S. L.J. 115, 133 (2000). One likely factor behind the settlement was the fact that the Manganese-based Fuel Additives Act had been invalidated by a Canadian arbitral tribunal, pursuant to an agreement among Canada's provinces, the Agreement on Internal Trade. See id.

96 Pub. Citizen \& Friends of THE EARTH, supra note 90, at 10; see also Haigh, supra note 95, at 125 (noting that, to the extent that statements of legislative intent are actionable, Chapter 11 "creates an opportunity for foreign [investors] . . to attempt to influence the legislative process); $c f$. EDWARD M. GRAHAM, FIGHTING THE WRONG ENEMY: ANTIGLOBAL ACTIVITIES AND MULTINATIONAL ENTERPRISES 41-43 (Inst. for Int'l Econ. ed., 2000) (discussing the "deep and troubling" implications of "Ethyl's NAFTA case against Canada," particularly its regulatory takings claim).

97 See infra notes 149-150 and accompanying text.

98 GRAHAM, supra note 96 , at 37. 
The Metalclad decision attracted immediate attention as the first and only ${ }^{99}$ Chapter 11 award to find a violation of NAFTA Article 1110, the expropriation provision. The case involved a U.S. investor who acquired a Mexican company to build and operate a hazardous waste disposal plant and landfill station in central Mexico. ${ }^{100}$ Metalclad alleged that before the purchase was consummated, Mexican federal authorities assured it that all necessary approvals for the project had been obtained. ${ }^{101}$ As Metalclad proceeded with construction, however, the governor of the state where the landfill was to be located publicly denounced the project and protesters actively demonstrated against it. ${ }^{102}$ Eventually, municipal authorities denied Metalclad a construction permit to build the waste station and the governor issued an ecological decree declaring the state a protected area, effectively preventing operation of the landfill. ${ }^{103}$ In response to Metalclad's claim, the arbitrators awarded it roughly $\$ 16.7$ million, ${ }^{104}$ finding that the denial of the construction permit and the issuance of the ecological decree expropriated Metalclad's investment. ${ }^{105}$ Professors Vicki Been and Joel Beauvais used the Metalclad award to highlight how a Chapter 11 tribunal's interpretation of Article 1110 potentially affords foreign investors greater protection than that available to U.S. investors under the Takings Clause of the Fifth Amendment."106 They stated that " $[\mathrm{t}] \mathrm{he}$

99 As of 2004, Metalclad was the only decision to find a violation of NAFTA art. 1110. See Gantz, Evolution of FTA Investment Provisions, supra note 22, at 731 \& n.220.

100 Metalclad Corp. v. United Mexican States, ICSID Case No. ARB(AF)/97/1, Award, I 2 (Aug. 30, 2000), 5 ICSID Rep. 212 (2002). The entity Metalclad acquired had operated a hazardous waste station on the same site, which closed due to local opposition to its operation. See PUB. CitizEn \& FrIends of THE EARTH, supra note 90, at 10-11.

101 See Metalclad, ICSID Case No. ARB(AF)/97/1, Award, 9T 33-35.

102 See id. 9 ๆ $37,46$.

103 Id. $1950,59-60$.

104 Id. I 131. The amount of the award was later reduced to $\$ 15.6$ million after a Canadian court, in an action to enforce the award, partially set it aside. See United Mexican States v. Metalclad Corp, 2001 BCSC 664, ๆף 133-1 35 (Can. B.C.) (B.C. Sup. Ct.).

105 Metalclad, ICSID Case No. ARB(AF)/97/1, Award, ๆ 104-112.

106 See Vicki Been \& Joel C. Beauvais, The Global Fifth Amendment? NAFTA's Investment Protections and the Misguided Quest for an International "Regulatory 
Metalclad award opened the door for property owners to use NAFTA to assert what we in the United States think of as 'regulatory takings' challenges to land use and environmental regulations,"107 suggesting that Metalclad would have been decided differently under U.S. takings jurisprudence. ${ }^{108}$

Metalclad is also significant because of the expansive manner in which the tribunal interpreted NAFTA Article 1105(1), the fair and equitable treatment provision. The tribunal found that the denial of a construction permit and the issuance of the ecological decree effectively denied Metalclad a "predictable framework" for planning its investment, thereby violating Article 1105(1). ${ }^{109}$ It interpreted Article 1105(1) as requiring the host state to act in a transparent manner regarding protected investments. ${ }^{110}$ Such a broad interpretation of the fair and equitable treatment standard, seen in Metalclad and other NAFTA awards, ${ }^{111}$ eventually prompted the NAFTA Free Trade Commission ${ }^{112}$ to adopt an interpretation of Article 1105(1) that was intended to narrow its scope, e.g., by emphasizing that "[t]he concepts of "fair and

Takings" Doctrine, 78 N.Y.U. L. REv. 30, 32-34, 37 (2003). The authors assert that NAFTA Chapter 11 decisions, including Metalclad, threaten to expand the scope of the host state's liability for regulatory takings beyond that of U.S. takings jurisprudence, for example, by ignoring the reasonableness of the investor's claimed investment-backed expectations, or by ignoring the reasonableness of the investor's reliance on governmental representations that later turn out to be false. $I d$. at 59-86.

$107 \mathrm{Id}$. at 33 .

$108 \mathrm{Id}$. at $72-78$ (explaining how a U.S. court likely would have applied the doctrines of "vested rights" and "estoppel" to reject Metalclad's claim).

109 Metalclad, ICSID Case No. ARB(AF)/97/1, Award, ๆf 99-101.

110 Id. $\uparrow 76$.

111 The other NAFTA awards include Pope \& Talbot, Inc. v. Gov't of Can., Award on the Merits of Phase 2, If 110-11 (NAFTA Arb. Trib Apr. 10, 2001), http://www.naftaclaims.com/Disputes/Canada/Pope/PopeFinalMeritsAward.pdf (finding that art. 1105(1)'s reference to "fair and equitable treatment" establishes an additional obligation beyond the international law minimum), and S.D. Myers, Inc. v. Gov't of Can., 40 I.L.M. 1408, 1438, ๆ 266 (NAFTA Arb. Trib. Nov. 13, 2000) (partial award under NAFTA/UNCITRAL) (finding that a breach of NAFTA's national treatment obligation also constitutes a violation of art. 1105(1)). See also Gantz, Evolution of FTA Investment Provisions, supra note 22, at 709-13 (discussing cases).

112 The NAFTA "Free Trade Commission is composed of cabinet-level representatives of the NAFTA parties," and has the power to issue binding interpretations of NAFTA's provisions. Lévesque, supra note 22, at 254 \& n.20 (citing NAFTA, supra note 2, art. 1131(2)). 
equitable treatment' and 'full protection and security' [in Article 1105(1)] do not require treatment in addition to or beyond that which is required by the customary international law minimum standard of treatment of aliens."113 Thus, although the outcome of Metalclad favored a U.S. investor, the tribunal's broad interpretation of NAFTA's expropriation and fair and equitable treatment provisions was controversial in the United States, especially because the measures at issue appeared to be driven by environmental protection and health concerns. ${ }^{114}$

In contrast to Ethyl and Metalclad, Loewen Group, Inc. v. United States ${ }^{115}$ and Methanex ${ }^{116}$ involved Canadian investors who brought Chapter 11 claims against the United States. Although the arbitral tribunals dismissed the investors' claims in both cases, the mere existence of the claims strongly affected public opinion in

113 NAFTA Free Trade Commission, Notes of Interpretation of Certain Chapter II Provisions, FOREIGN AFF. \& INT'L TRADE CAN., I 2 (July 31, 2001), http://www.international.gc.ca/trade-agreements-accords-commerciaux/disp-

diff/NAFTA-Interpr.aspx?lang=en\&view=d (discussing FTC Interpretation). The FTC Interpretation addresses two issues affecting Chapter 11 proceedings: confidentiality and the minimum standard of treatment under Article 1105(1). Id. If 1-2. As to the minimum standard of treatment, the FTC Interpretation states that:

1. Article 1105(1) prescribes the customary international law minimum standard of treatment of aliens as the minimum standard of treatment to be afforded to investments of investors of another Party.

2. The concepts of "fair and equitable treatment" and "full protection and security" do not require treatment in addition to or beyond that which is required by the customary international law minimum standard of treatment of aliens.

3. A determination that there has been a breach of another provision of the NAFTA, or of a separate international agreement, does not establish that there has been a breach of Article 1105(1).

Id. I 2; see also Gantz, Evolution of FTA Investment Provisions, supra note 22, at 713-14 (discussing the intent behind the FTC Interpretation regarding the minimum standard of treatment).

To the extent that the customary international law minimum standard of treatment is itself not clearly defined, Article 1105(1) remains ambiguous, even after the issuance of the FTC Interpretation. See Gantz, Evolution of FTA Investment Provisions, supra note 22 , at 714-15; Lévesque, supra note 22, at 256.

114 See Been \& Beauvais, supra note 106, at 35.

115 Loewen Grp., Inc. v. United States of America, ICSID Case No. ARB(AF)98/3, Award (June 26, 2003), 7 ICSID Rep. 442 (2005).

116 Methanex Corp. v. United States, 44 I.L.M. 1345 (NAFTA Chap. 11 Arb. Trib. August 3 , 2005) (final award); see also supra notes 7-10 and accompanying text. 
the United States towards BITs and investment arbitration. ${ }^{117}$ Loewen was significant because it was the first Chapter 11 claim filed against the United States. ${ }^{118}$ According to Vandevelde, the filing of Loewen's claim in October 1998 actually brought to a close the "second wave" of U.S. BIT negotiations that had lasted throughout much of the $1990 \mathrm{~s},{ }^{119}$ and prompted the government to reevaluate the U.S. Model BIT text in light of the prospect of defending future investment claims. ${ }^{120}$

Loewen involved a Canadian funeral home and funeral insurance company that had expanded its operations into the United States. ${ }^{121}$ Loewen and its U.S. subsidiary (collectively, "Loewen") were sued by a competitor company (O'Keefe) in Mississippi state court in connection with several contracts that had been concluded between Loewen and O'Keefe. ${ }^{122}$ After a trial before a predominantly African-American jury, in which the African-American judge allegedly allowed O'Keefe's attorneys to make numerous discriminatory and xenophobic comments regarding Loewen, the jury awarded O'Keefe $\$ 500$ million in damages. ${ }^{123}$ Rather than post the $\$ 625$ million bond required to pursue an appeal, Loewen settled O'Keefe's claim for $\$ 175$ million $^{124}$ and then brought a Chapter 11 claim against the United States, seeking approximately $\$ 725$ million in damages. ${ }^{125}$ Loewen asserted that the judge's conduct at trial was discriminatory, denied it fair and equitable treatment, and (in

117 See Been \& Beauvais, supra note 106, at 35-36.

118 See NAFTA Investor-State Arbitrations, supra note 85 (providing links to all notices of intent to file a Chapter 11 claim against the US).

119 VANDEVELDE, INVESTMENT AGREEMENTS, supra note 12, at 64-65. Between October 1998 and September 1999, the United States completed BIT negotiations with Mozambique, El Salvador, and Bahrain, states whose companies were unlikely to invest in the United States. Id. On the other hand, negotiations that were pending at the time with Venezuela and South Korea were abandoned. Id.

$120 \mathrm{Id}$.

121 See Loewen Grp., Inc. v. United States of America, ICSID Case No. ARB(AF)/98/3, Award (June 26, 2003) 7 ICSID Rep. 442 (2005).

122 Id. $\llbracket 3$.

123 Id. ๆๆ 3-4.

124 Id. $1916-7$.

125 U.S. Department of State, The Loewen Group, Inc. and Raymond L. Loewen $v$. U.S., NAFTA InVEstor-State ARbitrations: Cases Filed Against the United STATES OF AMERICA, http://www.state.gov/s/l/c3755.htm (last visited Oct. 7, 2012). 
conjunction with the Mississippi courts' alleged denial of Loewen's right to appeal through the bonding requirement) effectively expropriated Loewen's investment in violation of Chapter $11 .{ }^{126}$ While the claim was pending, observers expressed concern that Chapter 11 would, in effect, allow the Loewen tribunal, and potentially other arbitral tribunals, to review U.S. trial proceedings for error. ${ }^{127}$ Loewen's claim was eventually dismissed on jurisdictional grounds, ${ }^{128}$ but the language of the award suggests that the claim would have been dismissed in any event because Loewen failed to exhaust its domestic appeals of the Mississippi judgment prior to bringing its Chapter 11 claim. ${ }^{129}$ Yet at the time Loewen's claim was pending, the prospect of arbitrators subjecting the U.S. trial system to judgment by international arbitrators was unsettling to observers in the United States. ${ }^{130}$

126 See Loewen, ICSID Case No. ARB(AF)/98/3, Award, $\{39$.

127 See William S. Dodge, Loewen v. United States: Trials and Errors Under NAFTA Chapter Eleven, 52 DePaul L. REv. 563, 564 (2002) (using Loewen to argue against review by international tribunals as a means of correcting trial errors, and in favor of amending Chapter 11 to require exhaustion of domestic appeals before submitting a claim); NOW with Bill Moyers: Trading Democracy - a Bill Moyers Special (PBS television broadcast Feb. 1, 2002) [hereinafter Moyers Special] (posing the question whether the "jurors of Mississippi... [will] be overruled by the NAFTA tribunals"). A transcript of the broadcast is available at http://www.pbs.org/now/transcript/transcript_tdfull.html (last visited Oct. 7, 2011).

128 See Loewen, ICSID Case No. ARB(AF)/98/3, Award, If 220-40. While the arbitration was pending, Loewen reorganized in bankruptcy as a U.S. corporation, although it spun off its rights in the NAFTA arbitration to a newly-created Canadian subsidiary. The tribunal dismissed Loewen's claims, notwithstanding the fact that Loewen was Canadian at the time the claim was filed. Because the ultimate party in interest was now a U.S. citizen, the tribunal found that it lacked jurisdiction to adjudicate the claim under NAFTA Chapter 11. Id.

129 See id. ๆๆ 147-217. Although Chapter 11 does not require an investor to exhaust domestic remedies prior to filing an arbitration claim, see NAFTA, supra note 2, art. 1121 (in effect allowing investor to submit a claim without exhausting domestic remedies), the tribunal framed the issue as whether a judicial decision can amount to a denial of justice, and be actionable as a breach of NAFTA, where that decision was not appealed to the court of last resort. See Loewen, ICSID Case No. ARB(AF)/98/3, Award, IT 158-64 (explaining why NAFTA art. 1121 does not constitute a waiver of the international law doctrine that treats only decisions of the court of last resort as international wrongs).

130 See supra note 127 and accompanying text. 
Methanex, the target of Greider's critique in The Nation, ${ }^{131}$ has been described as the "most unnerving" of all of the Chapter 11 disputes. ${ }^{132}$ Although Methanex's claim, like Loewen's, was eventually dismissed, the size of the claim (close to $\$ 1$ billion) and the compelling public interest at stake in the dispute attracted the attention of NAFTA critics at a pivotal time in the evolution of U.S. BIT policy. ${ }^{133}$ The Methanex tribunal dismissed all but one of Methanex's claims on jurisdictional grounds in August 2002, ${ }^{134}$ and the remaining claim was dismissed in $2005 .{ }^{135}$ The tribunal found that California's actions banning the use or sale of MTBE were not sufficiently connected to Methanex to fall within the scope of NAFTA Chapter 11, which applies only to a NAFTA party's measures "relating to" the investors of another NAFTA party. ${ }^{136}$ But the filing and adjudication of the Methanex claim attracted public attention in the United States at the same time that Congress was enacting Trade Promotion Authority (TPA) legislation. $^{137}$ In addition to Greider's critique, the Methanex

131 See supra Part I (discussing Greider's critique of Methanex).

132 Vagts, supra note 9 , at xxv.

133 See, e.g., Greider, supra note 1, at 21-22.

134 Methanex Corp. v. United States, First Partial Award, ๆ 172 (NAFTA Chap. 11 Arb. Trib. Aug. 7, 2002), http://www.state.gov/documents/organization/12613.pdf.

135 Methanex Corp. v. United States, 44 I.L.M. 1345, Part IV, Chap. F, I 5 (2005) (NAFTA Chap. 11 Arb. Trib. Aug. 3, 2005) (final award).

136 Methanex Corp. v. United States, First Partial Award, 147 (NAFTA Chap. 11 Arb. Trib. Aug. 7, 2002), http://www.state.gov/documents/organization/12613.pdf, discussed in Sean D. Murphy, United States Practice IN INTERnational Law vol. 2: 2002-2004 168 (2006). NAFTA art. 1101(1) defines Chapter 11 as applying to measures adopted or maintained by a NAFTA party relating to investors of another NAFTA party. NAFTA, supra note 2, art. 1101(1). The tribunal found that most of Methanex's claim related to the indirect effect of the MTBE ban on Methanex's business interests as a methanol producer, which lacked the "legally significant connection" required by Article 1101(1) to confer standing. Methanex Corp. v. United States, First Partial Award, \147 (NAFTA Chap. 11 Arb. Trib. August 7, 2002), http://www.state.gov/documents/organization/12613.pdf. The tribunal allowed Methanex to re-plead its allegation that California's governor enacted the MTBE ban with the specific intent to harm foreign methanol producers. Id. \ๆ 151-52, 169. Ultimately this allegation was also dismissed for lack of jurisdiction. See Methanex Corp., 44 I.L.M. at 1460-61.

137 Bipartisan Trade Promotion Authority Act of 2002, 19 U.S.C. $\S \S 3801-3810$ (Supp. 2002) [hereinafter TPA]. Debate over TPA commenced with the introduction of proposed legislation in 2001, H.R. 3005, 107th Cong. (2002), and concluded in August 2002 when TPA was signed into law. As discussed below, the passage of TPA marked a 
dispute was the centerpiece of a New York Times investigation of Chapter 11 arbitration published in March $2001^{138}$ and was featured in a PBS documentary on the same topic in February 2002. ${ }^{139}$ The pending Methanex dispute caught the attention of Congress as well. When the House of Representatives voted on a TPA bill in December 2001, Methanex was cited by at least seven representatives in their statements opposing the legislation. ${ }^{140}$ Thus, the timing of Methanex played an important role in shaping U.S. policy towards investment protection.

Substantively, Methanex's claim was also very important. Methanex challenged measures adopted by the state of California to protect its water supply. ${ }^{141}$ As such, the dispute raised issues of crucial importance to environmentalists and other observers. NGOs submitted petitions to the Methanex tribunal seeking leave

shift in U.S. policy regarding investment agreements. See infra notes 182-186 and accompanying text.

138 Anthony DePalma, Nafta's Powerful Little Secret; Obscure Tribunals Settle Disputes, but Go Too Far, Critics Say, N.Y. TIMEs, Mar. 11, 2001, § 3. The article is based in part on interviews with representatives of Public Citizen, Earthjustice, and other NAFTA critics, who described the Methanex dispute as "one of the most worrisome" of the Chapter 11 disputes. Id at 13. The mayor of Santa Monica, California, referred to the Methanex claim as the "height of corporate moxie." Id.

139 Moyers Special, supra note 127. The broadcast featured coverage of some of the most contentious Chapter 11 disputes, including Methanex as well as Ethyl, Metalclad, and Loewen. Methanex in particular was described as having the potential to "upend democracy." Id.

A 2002 Business Week article on investor-state arbitration under NAFTA featured the Loewen dispute, but also referenced Methanex's complaint. Paul Magnusson, The Highest Court You've Never Heard of: Do NAFTA Judges Have Too Much Authority?, Bus. WK., Apr. 1, 2002, at 76-77, available at $\mathrm{http}: / /$ www.businessweek.com/magazine/content/02_13/b3776102.htm.

140 See 147 CONG. REC. 26,316 (2001) (statement of Rep. Kennedy); 147 ConG. REC. 25,922 (2001) (statement of Rep. Gilman); 147 CoNG. REC. 24,643 (2001) (statement of Rep. Waxman); 147 CoNG. ReC. 24,191 (2001) (statement of Rep. Stark); 147 Cong. ReC. 24,183 (2001) (statement of Rep. DeFazio); 147 CONG. ReC. 24, 168 (2001) (statement of Rep. Miller); 147 CONG. REC. 23,878 (2001) (statement of Rep. Lynch). The bill, House Bill 3005, H.R. 3005, 107th Cong. (2002), narrowly passed a House vote, but it was a different bill, House Bill 3009, H.R. 3009, 107th Cong. (2002), that was ultimately enacted into law. For a history of the enactment of TPA, see Hal Shapiro \& Lael Brainard, Trade Promotion Authority Formerly Known as Fast Track: Building Common Ground on Trade Demands More than a Name Change, 35 GEO. WASH. INT'L L. REV. 1, 19-28 (2003).

141 See 147 CONG. REC. 24,643 (2001) (statement of Rep. Waxman). 
to file amicus briefs for the tribunal's consideration highlighting the public interest at stake in the dispute. ${ }^{142}$ Several environmental NGOs $^{143}$ jointly submitted an application for amicus curiae status that noted how resolution of the dispute "[could] affect California's MTBE measures, as well as the willingness and ability of governments worldwide to implement measures to protect the environment or health in the future." 144 "A decision requiring the United States to compensate Methanex could create pressure on California to rescind the MTBE measures or affect the cost to U.S. and California taxpayers of maintaining them." International Institute for Sustainable Development, a Canadabased international NGO whose "mandate... is to foster... policies and practices in support of ... sustainable development," submitted an application that characterized the Methanex claim as "go[ing] to the heart of the limits placed by NAFTA on governmental authority... to ensure that economic development and sustainable development are integrated... policy objectives." 146

The pending Loewen and Methanex claims, especially in light of the pro-investor decision in Metalclad, were instrumental in crystallizing opposition to investment protection in the United States as Congress was deliberating over TPA. As Greider commented in a PBS interview that aired several months prior to

142 Notably, the Methanex tribunal was the first investment arbitration tribunal to accept amicus submissions. Howard ManN, The Final DeCision in MEthaneX $v$. UNITED STATES: SOME NEW WINE IN SOME NEW BotTles 11 (Int'1 Inst. for Sustainable Dev. ed., 2001), available at http://www.iisd.org/pdf/2005/commentary_methanex.pdf. The tribunal issued its decision in principle to allow amicus submissions in January 2001, and several NGOs later submitted applications for amicus curiae status along with amicus briefs in March 2004. Id at 11-12. The tribunal also authorized the hearings to be viewable to the public through a live closed-circuit television broadcast. Id. at 12 .

143 Participating NGOs included: Bluewater Network, Communities for a Better Environment, and the Center for International Environmental Law. Application of NonDisputing Parties for Leave to File a Written Submission at 3, Methanex Corp. v. United States (Mar. 9, 2004), available at http://www.state.gov/documents/ organization/30471.pdf.

$144 \mathrm{ld}$.

145 Id.

146 Application for Amicus Curiae Status by the International Institute for Sustainable Development, ๆ 7 5, 10, Methanex Corp. v. United States (Mar. 9, 2004), available at http://www.state.gov/documents/organization/30473.pdf. 
passage of the TPA legislation,

I think the public ... will be shocked and quite confused, if any of a number of cases, whether it's Methanex or Loewen,... manage[s] to win damages against the United States. People at first are gonna say, Huh? What is that about? And then, as it's explained to them, they're gonna say, we didn't sign on for that. That's not what we think about as a global trade agreement. And then the education process is quickly gonna turn into anger .... ${ }^{147}$

The prospect of the United States being held liable for billions of dollars to foreign investors challenging environmental and other regulation touched a nerve in the United States, generating substantial controversy over NAFTA Chapter $11 .^{148}$ As described in the next section, this controversy required supporters of TPA to make concessions, including a mandate to the executive branch to effect important changes in U.S. policy towards investment agreements. As discussed below, this shift in policy triggered changes to the investment chapters of FTAs that the United States concluded with Chile and Singapore and eventually shaped the content of the 2004 Model BIT.

\section{Effects on U.S. BIT Practice: MAI and TPA}

One of the earliest casualties of the post-NAFTA backlash against investment protection was the collapse of negotiations for the Multilateral Agreement on Investment (MAI) in December $1998 .^{149}$ If it had been enacted, the MAI would have contained similar investment protection commitments to those in most BITs and in NAFTA Chapter 11. ${ }^{150}$ The MAI was intended to bind only OECD member countries. ${ }^{151}$ The rationale behind limiting the

147 Moyers Special, supra note 127 (quoting William Greider).

148 See, e.g., id. $\lceil 7$.

149 See Been \& Beauvais, supra note 106 , at 35.

150 Based on the April 24, 1998 negotiating text (the last draft of the MAI produced before negotiations collapsed), the MAI would have included investor protections relating to non-discrimination, fair and equitable treatment, expropriation, transfers, performance requirements and investor-state dispute settlement. GRAHAM, supra note 96 , at 51, 57-63, 72-78. For an explanation of these provisions as they appear in most BITs, see supra notes 11,52 and accompanying text.

151 Graham, supra note 96, at 9. OECD stands for the Organization for Economic Co-operation and Development, an intergovernmental organization of mostly developed countries whose mission "is to promote policies to improve the economic and social 
MAI to OECD members was that these countries were "likeminded" in terms of investment protection and therefore would have little difficulty concluding an agreement containing rigorous investor protections. ${ }^{152}$ It turned out, however, that the countries negotiating the MAI were not as "like minded" as anticipated. ${ }^{153}$ Additionally, NGO activists, determined to frustrate the enactment of what they referred to as "NAFTA on steroids," mobilized to block its passage. ${ }^{154}$

The grassroots effort against the MAI was "unprecedented" in its international scope. ${ }^{155}$ Over 500 NGOs worldwide mobilized and expressed opposition to the MAI, including: citizens' watchdog groups The Council of Canadians and Public Citizen's Global Trade Watch; environmental groups such as Friends of the Earth and Sierra Club; and groups concerned about the effects of globalization, such as Oxfam and the Malaysia-based Third World Network. ${ }^{156}$ One diplomatic observer described the mobilization as "the first successful [i]nternet campaign by [NGOs]."

well-being of people around the world." OECD, About the OECD, http://www.oecd.org/about/ (last visited Aug. 26, 2012).

152 GrAHAM, supra note 96, at 9. As of 1998, the OECD's members included not only the United States, Japan, Canada, Australia, New Zealand and most European countries, but also Mexico, Turkey and South Korea. See OECD, List of OECD Member Countries - Ratification of the Convention on the OECD, http://www.oecd.org/general/ listofoecdmembercountries-ratificationoftheconventionontheoecd.htm (last visited Oct. 7, 2012).

153 See GraHAM, supra note 96 , at 25-35.

154 Id. at 39. Many of the protestors were perceived by MAI negotiators as less interested in dialogue than in putting an end to the negotiations. See CHARAN Devereaux, Robert Z. Lawrence \& Michael D. Watkins, Case Studies in US Trade Negotation: Vol. 1: MAKING the Rules 168 (Inst. for Int'l Econ. ed., 2006) (quoting one NGO representative who told negotiators, "[w]e killed fast track and we're going to kill the MAI").

155 DeVEREAUX, LAWRENCE \& WaKTINS, supra note 154, at 167.

$156 \mathrm{Id}$. at 161-62, 168 . The protestors presented a statement to the OECD formalizing their opposition to the MAI, signed by 560 NGOs from sixty-seven different countries. See NGO/OECD Consultation on the MAI, Joint NGO Statement on the Multilateral Agreement on Investment (MAI), http://www.web.net/coc/ngostatement.html (last visited Oct. 7, 2012).

157 Madelaine Drohan, How the Net Killed the MAI: Grassroots Groups Used Their Own Globalization to Derail Deal, THE Globe \& MaIL (CANADA), Apr. 29, 1998, at A1. Access to the internet enabled protesters such as the Council of Canadians in Canada and the Third World Network in Malaysia to quickly inform each other of new developments and pool information, thereby overcoming the secrecy in which the MAI negotiations 
such, the MAI protests were a rehearsal of sorts for the 1999 Seattle protests and helped to prepare NGOs to mobilize U.S. public opinion against investment protection during Congressional deliberations over TPA bills. ${ }^{158}$ The protestors characterized the MAI negotiations as being shrouded in secrecy and "skewed" in favor of corporate investors. ${ }^{159}$ They frequently invoked the Ethyl dispute $^{160}$ to warn that the MAI, like NAFTA Chapter 11, could be used by corporations to strike down legitimate regulation, such as measures to protect the environment. ${ }^{161}$ It is likely that the MAI talks would have collapsed in any event. Factors that complicated the MAI negotiations included the U.S. passage of the HelmsBurton Act in 1996, European insistence on an exception from the most-favored nation obligation with respect to regional economic integration organizations, and France and Canada's insistence on an exception to the treaty for "cultural industries." 162 Nonetheless, the NGOs' intense and vocal opposition to the MAI certainly contributed to the collapse of the negotiations. ${ }^{163}$

Perhaps the collapse of the MAI is evidence that developed countries, faced with the prospect of hosting foreign investment from other MAI countries, were not willing to commit to the strong investment protections that they themselves had pressured capital-importing countries to undertake. ${ }^{164}$ The MAI's demise was perceived by many in Brazil, for example, as a sign that "there

were allegedly conducted. Id.

158 See GraHAM, supra note 96, at 48 .

159 Devereaux, LAWRENCE \& WATKINS, supra note 154, at 163-64.

160 See supra notes 91-98 and accompanying text.

161 DeVEREAUX, LAWRENCE \& WATKINS, supra note 154, at 164; GraHAM, supra note 96 , at 39 ;

162 Graham, supra note 96 , at 25-35.

163 Id. at 35. Indeed, one of the negotiators suggested that involving the NGOs in discussions "may have been what sank the MAI." DEVEREAUX, LAWRENCE \& WATKINS, supra note 154, at 167 . It was at the MAI negotiations in Paris that many of the protestors met for the first time and exchanged business cards. Ironically, the site of the MAI negotiations was a forum that facilitated anti-globalization protestors in establishing their network. Id.

164 See José Gilberto SCANDIUCCI FILHo, The BraziLIan ExPERIENCE WITH Bilateral Investment Agreements: A Note 4-5 (U.N. Conference on Trade \& Dev. ed., 2007), available at http://archive.unctad.org/sections/wcmu/docs/ c2em21p15_en.pdf. 
was something to fear" about BITs. ${ }^{165}$ This perception contributed to the refusal by the Brazilian parliament to ratify numerous BITs that the government had signed in the 1990s. ${ }^{166}$ In any event, the collapse of the MAI negotiations illustrated the potential lobbying power of NGOs in the age of the internet and demonstrated that concluding an agreement on investment protection among capitalexporting countries was more difficult than anticipated.

As for TPA, its enactment was characterized by deep disagreements within Congress over issues of free trade and globalization, and by the ongoing controversy over NAFTA Chapter 11. ${ }^{167}$ TPA legislation, or what used to be known as "fast track" legislation, bypasses procedural obstacles to the implementation of international trade agreements. ${ }^{168}$ If a trade agreement is concluded under TPA, Congress will adopt implementing legislation in an expedited manner, without amendments or filibusters. ${ }^{169}$ In exchange, TPA enumerates objectives to guide the executive branch in negotiating the treaty, and Congress is given a supervisory role in the treaty negotiation process. ${ }^{170}$ Although Congress consistently renewed fast track legislation throughout the 1970 s and 1980s, the issue has become more polarized in recent decades. ${ }^{171}$

Passage of TPA in 2001 and 2002 was particularly divisive. In December 2001, a TPA bill passed the House of Representatives by a mere one-vote margin. ${ }^{172}$ Much of the controversy over TPA involved the politics of international trade, but a good deal of it stemmed from concerns about investment protection and NAFTA Chapter 11. ${ }^{173}$ Some of the same consumer rights and

165 Id. For a discussion of the history of Brazil's approach to BITs and investment arbitration, see infra Part III.B.2.D

166 FiLHO, supra note 164, at 4-5; See also infra Part III.B.2.D.

167 See supra note 140 and accompanying text.

168 See Shapiro \& Brainard, supra note 140, at 10-16 (describing the "fast track" procedure).

169 See id. at 15-16.

170 See id. at 11-13.

171 DEVEREAUX, LAWRENCE \& WATKINS, supra note 154 , at 187 . For example, in 1997 and 1998, the Clinton administration fought unsuccessfully to enact "fast track" legislation. Id. at 220-28.

172 Id. at 230.

173 See VANDEVELDE, INVESTMENT AgREEMENTS, supra note 12, at 70 (noting that 
environmental NGOs that protested against the MAI also lobbied against TPA. ${ }^{174}$ In September 2001, as the House began work on a TPA bill, Public Citizen and environmental NGO Friends of the Earth issued a roughly fifty-page report, arguing that NAFTA Chapter 11 issues had become "central" to the debate over TPA, and invoking several of the most controversial Chapter 11 disputes as evidence for why Congress should oppose TPA. ${ }^{175}$ In their statements discussing the TPA bill, members of Congress repeatedly expressed concern over NAFTA's investment protection provisions, citing examples of controversial Chapter 11 disputes such as Methanex. ${ }^{176}$ In 2002, as the House and Senate worked on a conference version of the TPA bill, a group of thirtyfive state attorneys general and the U.S. Conference of Mayors

"[i]nvestment policy became a visible and controversial issue during the enactment of the TPA.").

174 See Business, Environmentalists Clash over TPA Investor Protections, INSIDE U.S. TRADE, Oct. 19, 2001, 77 (describing how environmentalists opposed a TPA bill because it failed to scale back investor protections from those in NAFTA Chapter 11).

175 See Pub. Citizen \& Friends of the Earth, supra note 90, at iii. The report warned of the consequences of enabling the expansion of NAFTA-like investor protections to the proposed Free Trade Area of the Americas:

As a new Fast Track fight looms in Congress in the fall of 2001, the sovereignty and public policy implications of the NAFTA cases reviewed in this report argue against the use of Fast Track for the development of the proposed FTAA and more generally as a tool of democratic decision-making and public policy. Id.

176 See 147 ConG. ReC. 26,316 (2001) (statement of Rep. Kennedy); 147 CoNG. REC. 25,922 (2001) (statement of Rep. Gilman); 147 CONG. REC. 24,643 (2001) (statement of Rep. Waxman); 147 CONG. REC. 24,191 (2001) (statement of Rep. Stark); 147 ConG. REC. 24,183 (2001) (statement of Rep. DeFazio); 147 Cong. REC. 24,168 (2001) (statement of Rep. Miller); 147 CONG. REC. 23,878 (2001) (statement of Rep. Lynch); see also 148 CONG. REC. 8,291-92 (2002) (statement of Sen. Kerry) (observing concern of many in US regarding "the effect of NAFTA's investment settlement dispute process ... on the ability of ... States to promulgate legitimate health and safety laws"); 148 CONG. REC. 6,711-12 (2002) (statement of Sen. Dorgan) (discussing the secrecy of Chapter 11 tribunals and the "chilling effect" of claims like Methanex's on environmental regulation); 148 CONG. REC. 6,703 (2002) (statement of Sen. Baucus) [hereinafter Baucus Statement] (discussing the need to balance investment protections against "the legitimate needs of regulatory agencies, and the concerns of environmental and public interest groups"); 148 CONG. REC. 6,433 (statement of Sen. Hollings) (reading into the record a Business Week article describing the "secretive process" of NAFTA panels); 148 CONG. REC. 5,994-95 (2002) (statement of Sen. Wellstone) (criticizing the TPA bill for failure to limit expropriation guarantees); supra note 140 and accompanying text. 
wrote to members of Congress, urging them to limit investment protections in the TPA bill. ${ }^{177}$ In May 2002, Senator John Kerry proposed an amendment to TPA that would have dramatically limited the investment protection commitments of any trade agreement concluded under TPA. ${ }^{178}$ Although the Kerry amendment was ultimately defeated, it enjoyed substantial support both in and out of Congress. ${ }^{179}$

In light of the uncertain prospect of TPA's passage and in response to the concerns expressed regarding NAFTA Chapter 11, supporters of TPA made concessions to ensure passage of the bill. The most significant compromise provisions expanded trade adjustment assistance to U.S. workers whose jobs are displaced

177 Local Officials Urge Trade Conferees to Limit Investor Protections, INSIDE U.S. TRADE, July 26, 2002, 97 1-7, 9-11. In July, state attorneys general wrote to House Ways and Means Committee Chair Bill Thomas and Senate Finance Committee Chairman Max Baucus, urging that the investment section of the TPA bill: (i) stipulate that foreign investors have no greater rights to compensation than U.S. citizens; (ii) deny arbitrators the right to award foreign investors compensation that goes beyond U.S. standards; and (iii) deny arbitrators jurisdiction to award foreign investors compensation based on the rulings of U.S. courts. Id. at 2, 5-6. In June 2002, the U.S. Conference of Mayors issued a similar resolution. US Conference of Mayors, Proposed Resolutions: 70th Annual Conference of Mayors, 163-65, http://www.usmayors.org/ 70thAnnualMeeting/2002resolutions.pdf (last visited Oct. 7, 2012).

178148 CONG. REC. 8,092 (2002) (text of Senate Amendment 3430). The proposed amendment required that the investment protection provisions of any trade agreement: (i) limit the expropriation guarantee by excluding compensation for "measures that cause a mere diminution" in property value; (ii) exempt from the expropriation and fair and equitable treatment guarantees legitimate regulation to protect health, safety and welfare, the environment or public morals; and (iii) require a foreign investor to submit an investment claim to a "competent authority" in the home country prior to bringing the claim to investment arbitration. Id . I 2102(b)(3)(D), (G), and (H).

179 Of the ninety-six senators that voted on the Kerry amendment, forty-one voted in favor (the amendment was defeated by a 55-41 vote). Senate Defeats Kerry Investment Amendment to Trade Bill, INSIDE U.S. TRADE, May 21, 2002, ๆๆ 1-2. Numerous groups outside the Senate submitted letters expressing support for the Kerry amendment. See Consumers Union Backs Kerry Amendment, InSIDE U.S. TradE, May 22, 2002, 19 1-4; Environment, Local Government Groups Back Kerry Investment Amendment, INSIDE U.S. TRADE, May 15, 2002, 19 1-7; Letter to Max Baucus, U.S. Senator, from Mike McGrath, Att'y Gen., State of Montana (May 14, 2002), in Montana Attorney General Backs Kerry Investment Amendment, INSIDE U.S. TRADE, May 16, 2002, I1 1-5; Oklahoma Legislature Resolution Backs Kerry Investment Amendment, InSIDE U.S. TradE, May 15, 2002, ff 1-9; Letter to Charles Rangel, U.S. Congressman, from Jay Insley, Earl Blumenauer, \& Brian Baird, Members of U.S. Congress (May 16, 2002), in Pro-Trade House Democrats Back Kerry Amendment, INSIDE U.S. TRADE, May 20,2002 , 1 ⿰ा1 1-4. 
due to foreign trade. ${ }^{180}$ However, TPA supporters compromised on investment protection as well. Senate Finance Committee Chairman Max Baucus, who led TPA negotiations in the Senate, repeatedly emphasized that the result of the TPA process should be investment agreements that achieve a balance between protecting U.S. investors abroad and defending the regulatory authority of the United States. ${ }^{181}$ TPA was signed into law in August 2002. ${ }^{182}$ It defined the U.S. principal negotiating objectives with respect to foreign investment as (i) ensuring that foreign investors in the United States "are not accorded greater substantive rights with respect to investment protections" than those available to U.S. investors, and (ii) securing for investors protections that are "comparable" to those available under U.S. law. ${ }^{183}$ Framing the principal negotiating objectives as limiting protection to foreign investors has been described as an unprecedented and "major" shift in U.S. investment treaty policy. ${ }^{184}$ TPA also enumerated specific negotiation objectives that similarly limit investment protection, including: (i) establishing standards for expropriation and fair and equitable treatment "consistent with United States legal principles and practice"; ${ }^{\prime 185}$ (ii) improving investor-state arbitration procedures by

180 See DeVereaux, LAWRENCE \& WaTKINS, supra note 154, at 230-31; see also Shapiro \& Brainard, supra note 140, at 26.

181 In a speech to the International Institute of Economics, Senator Baucus described how the House TPA bill passed by single vote, emphasizing the need to craft a broader bipartisan consensus on TPA. In commenting on the Senate version of the bill, he referred to the controversy over NAFTA Chapter 11 and noted how the Senate bill attempted to address some of the concerns raised about investment protection. See Baucus Suggests Potential for Changing TPA-TAA Bill Limited, INSIDE U.S. TRADE, Feb. 26, 2002, ๆT 3-7; see also Baucus Says TPA Allows Government Screen for Investment Suits, InSIDE U.S. TRADE, Mar. 26, 2002, ๆ 1 [hereinafter Baucus Says TPA] (stating to then-U.S. Trade Representative Robert Zoellick that the result of TPA "should be investment agreements that balance our interest in protecting US investors abroad with our interest in defending the regulatory authority of government at all levels in the United States"); Baucus Statement, supra note 176; see also infra note 185 and accompanying text.

182 See MURPHY, supra note 136, at 157.

183 TPA $\S 3802(\mathrm{~b})(3)$.

184 VANDEVELDE, INVESTMENT AGREEMENTS, supra note 12, at 73-74; see also Gantz, Evolution of FTA Investment Provisions, supra note 22, at 73-75 (describing the TPA language as a compromise that "failed to fully satisfy anyone").

185 TPA $\S 3802$ (b)(3)(D)-(E). 
enabling public input, deterring frivolous claims, and providing a mechanism to appeal arbitral decisions; ${ }^{186}$ and (iii) enhancing transparency in investor-state arbitration by publishing all proceedings, submissions and decisions, making hearings of the arbitral tribunal open to the public, and establishing a mechanism for amicus submissions. ${ }^{187}$

To summarize, although the Kerry amendment did not pass, TPA's negotiation objectives reflect the concerns about NAFTA Chapter 11 raised by Senator Kerry and others during Congressional deliberation over TPA. As the Senate Finance Committee's report on the TPA bill acknowledged, the negotiation objectives are shaped by the fact that the United States may find itself on either side of an investor-state arbitration dispute:

The negotiating objective on foreign investment reflects the Committee's view that it is a priority for negotiators to seek agreements protecting the rights of U.S. investors abroad . . . It also reflects the view that in entering into investment agreements, negotiators must seek to protect the interests of the United States as a potential defendant in investor-state dispute settlement. In other words, there ought to be a balance. Protecting the rights of U.S. investors abroad should not come at the expense of making Federal, State and local laws and regulations unduly vulnerable to challenge by foreign investors. $^{188}$

In other words, TPA seeks a more balanced approach to investment protection because the United States increasingly operates under a "veil of ignorance" as to its vested interests relating to investment protection.

The TPA's negotiation objectives regarding investment guided the United States in negotiating the investment chapters of the U.S.-Chile Free Trade Agreement (FTA) ${ }^{189}$ and the U.S.Singapore FTA. ${ }^{190}$ Negotiations for these FTAs had been ongoing

$186 I d . \S 3802(\mathrm{~b})(3)(\mathrm{G})$.

187 Id. $\S 3802(\mathrm{~b})(3)(\mathrm{H})$.

188 S. REP. No. 107-139, at 13 (2002) (emphasis added).

189 United States-Chile Free Trade Agreement, U.S.-Chile, June 6, 2003, http://www.ustr.gov/trade-agreements/free-trade-agreements/chile-fta/final-text [hereinafter U.S.-Chile FTA].

190 United States-Singapore Free Trade Agreement, U.S.-Sing., May 6, 2003, $\mathrm{http}: / /$ www.ustr.gov/trade-agreements/free-trade-agreements/singapore-fta/final-text 
since $2000,{ }^{191}$ and the investment chapters for both agreements were concluded only a few months after TPA's enactment in August 2002. ${ }^{192}$ In fact, then-U.S. Trade Representative Robert Zoellick had been considering options for implementing the TPA's investment objectives as early as March $2002 .{ }^{193}$

The 2004 Model BIT, ${ }^{194}$ in turn, is modeled off of the U.S.Chile and U.S.-Singapore FTAs, as well as NAFTA. ${ }^{195}$ Although BITs, which do not address trade issues, technically are not governed by TPA, ${ }^{196}$ there were practical reasons why the State Department and the Office of the U.S. Trade Representative (USTR) ${ }^{197}$ made the 2004 Model BIT provisions consistent with the investment chapters of the recently-concluded FTAs. These reasons included the desirability of establishing a coherent and uniform treaty practice ${ }^{198}$ and the existence of most-favored nation

[hereinafter U.S.-Singapore FTA]; see also VANDEVELDE, INVESTMENT AGREEMENTS, supra note 12, at 71 (noting that TPA's negotiating objectives "provided the guidance from Congress that allowed U.S. negotiators to complete the preparation of" the U.S.Chile FTA and U.S.-Singapore FTA investment chapters); Gantz, Evolution of FTA Investment Provisions, supra note 22, at 707 (observing that the investment chapter of the U.S.-Chile FTA "obviously was designed in significant part to comply with the TPA objectives").

191 See MURPHY, supra note 136, at 158, 161.

192 A proposed investment chapter to the U.S.-Chile FTA was drafted by early October 2002, and most of the investment chapter to the U.S.-Singapore FTA was complete by November 2002. See VANDEVELDE, INVESTMENT AgREEMENTS, supra note 12 , at 71 .

193 See Baucus Says TPA, supra note 181, If 2 (referring to the fact that Zoellick already had been considering options for putting the investment protection provisions of TPA into effect).

1942004 Model Bilateral Investment Treaty, U.S. DEP'T OF STATE, http://www.state.gov/documents/organization/117601.pdf (last visited Oct. 7, 2012) [hereinafter 2004 Model BIT].

195 See Gantz, supra note 22, at 729 n.214.

196 See TPA, \& 3802(b)(3).

197 Whereas USTR is principally responsible for negotiating FTAs, USTR and the State Department share responsibility for negotiating BITs. See Bilateral Investment Treaties and Related Agreements, U.S. DEP'T OF STATE, http://www.state.gov/e/eb/ifd/bit/index.htm [hereinafter BITs and Related Agreements] (last visited Oct. 7, 2012); see also VANDEVELDE, INVESTMENT AGREEMENTS, supra note 12 , at 92 (noting that primary responsibility for the BIT program shifted from the State Department to USTR in 1980 , but over time the two agencies developed a practice of sharing responsibility for negotiating BITs).

198 See VANDEVELDE, INVESTMENT AGREEMENTS, supra note 12, at 97. 
clauses in BITs and FTAs, which raised the prospect of foreign investors under one treaty invoking the protections of another. ${ }^{199}$ In fact, in developing the investment chapters to the U.S.-Chile and U.S.-Singapore FTAs, USTR worked with the State Department and members of Congress with the expectation that the FTA provisions would also serve as a model for future BITs. ${ }^{200}$ Hence, in 2003 and 2004, USTR and the State Department revised the Model BIT in order to conform to the recently-concluded FTAs and issued a draft of the 2004 Model BIT in February $2004{ }^{201}$

Table 1 below provides a chronology of the events discussed in the previous section, culminating in the issuance of the 2004 U.S. Model BIT. The chronology illustrates how, by shaping public opinion during the passage of TPA, the backlash against Chapter 11 ultimately affected U.S. practice regarding FTAs and BITs. Part II.C describes some of the resulting changes in U.S. BIT practice, as reflected in the 2004 U.S. Model BIT.

199 See id. at 72.

200 See id. at 71.

201 MurPhy, supra note 136, at 163; see also Mark Kantor, The New Draft Model U.S. BIT: Noteworthy Developments, 21 J. INT'L ARB. 383, 385 (2004) (describing the objective of the 2004 Model BIT as providing a consistent U.S. approach to negotiating FTAs and BITs). 
Table 1: Chronology of Events Affecting Evolution of U.S. Model BIT ${ }^{202}$

\begin{tabular}{|c|c|}
\hline Date & Event \\
\hline January 1994 & NAFTA enters into force. \\
\hline January 1997 & Investor files claim in Metalclad v. Mexico. \\
\hline April 1997 & Investor files claim in Ethyl v. Canada. \\
\hline July 1998 & Ethyl claim settles (\$13 million paid). \\
\hline October 1998 & $\begin{array}{l}\text { Investor files claim in Loewen } v \text {. United } \\
\text { States. }\end{array}$ \\
\hline December 1998 & MAI negotiations are terminated. \\
\hline December 1999 & $\begin{array}{l}\text { Investor files claim in Methanex } v \text {. United } \\
\text { States. }\end{array}$ \\
\hline Aug & $\begin{array}{l}\begin{array}{l}\text { Metalclad award issued } \\
\text { paid). }\end{array}{ }^{203}\end{array}$ \\
\hline Nov.-Dec. 2000 & $\begin{array}{l}\text { United States begins FTA negotiations with } \\
\text { Chile and Singapore. }\end{array}$ \\
\hline December 2001 & TPA bill narrowly passes House. \\
\hline August 2002 & ed into law. \\
\hline 2002 & $\begin{array}{l}\text { Methanex partial award issued (dismissing } \\
\text { most of investor's claims). }\end{array}$ \\
\hline $\begin{array}{l}\text { Dec. 2002- } \\
\text { Jan. } 2003\end{array}$ & $\begin{array}{l}\text { Negotiations completed on U.S.-Chile and } \\
\text { U.S.-Singapore FTAs. }\end{array}$ \\
\hline June 2003 & Loewen award issued (claim dismissed). \\
\hline 2004 & Singapore FTAs enter into force. \\
\hline February 2004 & $\begin{array}{l}\text { USTR and State Department issue draft } 2004 \\
\text { Model BIT. }\end{array}$ \\
\hline
\end{tabular}

202 See NAFTA, supra note 2, art. 2203; Ethyl Corp. v. Gov't of Canada, 38 I.L.M. 708 (NAFTA Chap. 11 Trib. June 24, 1998) (award on jurisdiction under NAFTA/UNCITRAL); Metalclad Corp. v. United Mexican States, ICSID Case No. ARB(AF)/97/1, Award (Aug. 30, 2000), 5 ICSID Rep. 212 (2002); Loewen Grp., Inc. v. United States, ICSID Case No. ARB(AF)/98/3, Award (June 26, 2003), 7 ICSID Rep 442 (2005); Methanex Corp. v. United States, 44 I.L.M. 1345 (2005) (NAFTA Chap. 11 Arb. Trib. Aug. 3, 2005) (final award); VANDEVElDE, INVESTMENT AGREEMENTS, supra note 12, at 96-98; MURPHY, supra note 136, at 157-63; Haigh, supra note 95 at 121, 133; GrAHAM, supra note 96, at 12; Lévesque, supra note 22, at 255; Shapiro \& Brainard, supra note 140 , at 27.

203 Although the arbitral tribunal awarded Metalclad $\$ 16.7$ million, that amount was later reduced to $\$ 15.6$ million. See supra note 105 and accompanying text. 


\section{New Generation of U.S. BITs and FTAs}

Including the recently-enacted FTAs with Korea, Panama, and Colombia, the United States has concluded FTAs containing investment chapters with fifteen countries since the enactment of TPA, ${ }^{204}$ and has concluded two BITs (with Uruguay and Rwanda) since the 2004 Model BIT was issued. ${ }^{205}$ These BITs and FTA investment chapters represent a new generation of U.S. investment agreements. Vandevelde described the 2004 Model BIT as a product of the "most extensive revision of the model negotiating text in the history of the BIT program."206 It is ironic that this profound reform of the U.S. Model BIT occurred during the administration of President George W. Bush. In 2009 the Obama administration established an interagency panel to review and revise the 2004 Model BIT text. ${ }^{207}$ But after over two years of

204 The United States concluded FTAs containing investment chapters with Australia, Morocco, Chile, Singapore, and the CAFTA-DR countries (Costa Rica, Dominican Republic, El Salvador, Guatemala, Honduras, and Nicaragua) in 2004; with Panama, Oman, and Peru in 2006; and with Korea and Colombia in 2007. Free Trade Agreements, Office of the United States Trade Representative [hereinafter USTR, Free Trade Agreements], http://www.ustr.gov/trade-agreements/free-trade-agreements (last visited Oct. 7, 2012).

The United States-Australia FTA, unlike the other FTAs, does not provide for investor-state arbitration of disputes. United States-Australia Free Trade Agreement, U.S.-Austl., art. 11.16, May 18, 2004, available at http://www.ustr.gov/sites/default/files/uploads/agreements/fta/australia/asset_upload_file 248_5155.pdf (providing only for consultations between the parties on developing procedures for investor-state dispute settlement). It has been suggested that the reason for omitting an investor-state arbitration mechanism from the FTA was to avoid the experience of the United States and Canada under NAFTA. See William S. Dodge, Investor-State Dispute Settlement Between Developed Countries: Reflections on the Australia-United States Free Trade Agreement, 39 Vand. J. Transnat'L L. 1, 3 (2006); see also Gagné \& Morin, supra note 22, at 372-373 (suggesting that the absence of investor-state dispute settlement procedures is acceptable to the United States only for investment agreements with countries possessing a legal system comparable to that of the United States, but also noting that Australia is a significant capital exporter to the United States).

205 See BITs and Related Agreements, supra note 197. The United States-Uruguay BIT was concluded in 2005 and entered into force in 2006; the United States-Rwanda BIT was concluded in 2008 and entered into force in 2012. Id.

206 VANDEVELDE, INVESTMENT AGREEMENTS, supra note 12, at 105.

207 See Press Release, Office of the United States Trade Representative, United States Concludes Review of Model Bilateral Investment Treaty (Apr. 20, 2012), http://www.ustr.gov/about-us/press-office/press-releases/2012/april/united-statesconcludes-review-model-bilateral-inves. 
review and stalemate ${ }^{208}$ in March 2012 the State Department and USTR released a 2012 Model BIT $^{209}$ that in key respects is identical to the 2004 Model BIT. With minor exceptions, the provisions of the 2004 BIT that are described below were left virtually unchanged in the 2012 Model BIT. ${ }^{210}$

This section contrasts certain aspects of the 2004 Model BIT with the U.S.-Argentina BIT discussed above to illustrate how the congressional mandate expressed in TPA and the prospect of the United States finding itself on either side of investor-state disputes have moderated some of the most strongly pro-investor aspects of

208 In September 2009, a subcommittee of the State Department's Advisory Committee on International Economic Policy (ACIEP) issued a report on recommended changes to the model BIT, but the report revealed deep disagreement within the committee as to whether and how the model BIT should be changed. See Report of the Subcommittee on Investment of the ACIEP Regarding the Model Bilateral Investment Treaty, U.S. DEP'T OF STATE (2009), http://www.state.gov/e/eb/rls/othr/2009/131118.htm [hereinafter ACIEP] (last visited Aug. 29, 2012). Although the administration had planned to conclude the review by the end of 2009, apparently disagreements over environmental, labor and other issues stalled the process. See Amy Tsui, U.S. Business Groups Write Clinton, Kirk Supporting Indian BIT Talks in August, 28 BNA INT'L TRADE RPTR 1246 (2011) (citing environmental, labor, transparency and public participation provisions as "likely sticking points" in the review process); see also China Update, INSIDE U.S. TRADE, June 11, 2010, $\$ 8$ (citing discord within the administration and among members of Congress over labor and environmental issues as the cause of delay).

The impasse over the model BIT text held up BIT negotiations with India and China, and most likely the Trans-Pacific Partnership negotiations as well. See Business Sends Obama Mixed Messages on Disciplining SOEs in BITs, InSIDE U.S. TRADE, Jan. 29, 2010, 17 1-9; Tsui, supra, at 1246; David Gantz, Trans-Pacific Partnership Negotiations: Waiting for U.S. Proposals, KluwerArbitrationBlog.Com (June 20, 2011) [hereinafter Gantz, Trans-Pacific Partnership Negotiations], http://kluwerarbitrationblog.com/blog/201 1/06/20/trans-pacific-partnership-negotiationswaiting-for-u-s-proposals/.

2092012 U.S. Model Bilateral Investment Treaty, U.S. DEP'T OF STATE, http://www.state.gov/documents/organization/188371.pdf [hereinafter 2012 Model BIT].

210 The 2012 Model BIT deletes Annex D, which set aspirational goals for establishing an appellate review mechanism for investor-state arbitration, as discussed infra note 234. Additionally, the 2012 Model BIT makes some changes to the treaty exception for certain financial services measures. See Paolo Di Rosa, The New 2012 U.S. Model BIT: Staying the Course, KluwerArbitrationBlog.Com (June 1, 2012), http://kluwerarbitrationblog.com/blog/2012/06/01/the-new-2012-u-s-model-bit-stayingthe-course/; see also Luke Eric Peterson, United States Unveils 'New' Model Bilateral Investment Treaty that Retains Protective Core, and Makes a Few Tweaks on Periphery, INV. ARB. REP. (2012) http://www.iareporter.com/articles/20120422_2 (last visited Oct. 7,2012 ) (subscription required). 
past treaties. $^{211}$

\section{Preamble}

Arbitral tribunals, following the Vienna Convention on the Law of Treaties, interpret BITs in light of the treaty's object and purpose. $^{212}$ Tribunals have relied in particular on a BIT's preamble in determining the object and purpose of a given treaty. ${ }^{213}$ Traditionally, preambles have stated that the purpose of a BIT is to protect and promote investments, which has led tribunals to interpret BIT provisions in a pro-investor manner. ${ }^{214}$ The preamble of the U.S.-Argentina BIT, for example, refers to the parties' desire to reciprocally encourage and protect investment in order to promote economic cooperation, stimulate capital flows, and maintain a stable investment framework. ${ }^{215}$

In contrast, the preamble to the 2004 Model BIT, while retaining the references to economic cooperation, capital flows and stable investment framework, also adds two objectives: providing an effective means of asserting investor claims "under national law as well as through" arbitration; and, significantly, achieving the other objectives of the treaty "in a manner consistent with the protection of health, safety, and the environment, and the promotion of internationally recognized labor rights. ${ }^{216}$ In other

211 This is not an exhaustive list of the changes made to the 2004 model. For a more comprehensive comparison of the 2004 model with earlier models, see Kenneth J. Vandevelde, A Comparison of the 2004 and 1994 U.S. Model BITs, in Y.B. ON INT'L INV. L. \& POL'Y: 2008-2009 283-315 (Karl P. Sauvant ed., 2009); see also Alvarez, supra note 19, at 9-13; Kantor, supra note 201.

212 Vienna Convention on the Law of Treaties art. 31(3), May 23, 1969, 1155 U.N.T.S. 331 .

213 See Andrew Newcombe \& Lluís Paradell, Law and Practice of INVESTMENT TREATIES: StandARDS OF TREATMENT 113-14 \& n.174 (2009) (citing decisions). The preamble has been particularly influential to tribunals interpreting the fair and equitable treatment provision in BITs. Id.

214 See id. at 114-15.

215 See U.S.-Arg. BIT, supra note 38, pmbl. The preamble also recognizes that promoting economic cooperation can in turn "promote respect for internationally recognized worker rights." Id. For an example of an arbitral award interpreting the preamble of the U.S.-Argentina BIT in a pro-investor manner, see Siemens A.G. v. Argentine Republic, ICSID Case No. ARD/02/8, Decision on Jurisdiciton, I 81 (Aug. 3, 2004), 12 ICSID Rep. 174 (2007), quoted in NEWCOMBE \& PARADELL, supra note 213, at 114.

2162004 Model BIT, supra note 194, pmbl. 
words, unlike earlier models, the 2004 model expressly weighs investor protection objectives against the host state's interest in promoting the public interest. Alvarez suggests that the object and purpose of the 2004 Model BIT reflects a "new-found awareness" that promoting private ownership and free markets "does not produce the desired beneficial outcomes" anticipated by the preambles of earlier BITs. ${ }^{217}$

\section{Limits on Indirect Expropriation}

As stated, ${ }^{218}$ the expropriation guarantee in the U.S.-Argentina BIT includes outright and indirect takings as well as regulatory measures that are "tantamount" to an expropriation. ${ }^{219}$ The 2004 Model BIT replaces the word "tantamount" with "equivalent."220 Consistent with TPA's mandate to secure investor protections that are "comparable" to those available under U.S. law, the 2004 model also requires the expropriation provision to be interpreted in accordance with annexed language that defines indirect expropriation by reference to factors derived from U.S. takings jurisprudence. ${ }^{221}$ Most importantly, the 2004 model clarifies that "[e]xcept in rare circumstances, non-discriminatory regulatory actions by a Party that are designed and applied to protect legitimate public welfare objectives, such as public health, safety, and the environment, do not constitute indirect expropriations."222 As others have noted ${ }^{223}$ this language will make it significantly more difficult for investors such as Metalclad to convince an arbitral tribunal that a regulatory measure, particularly an environmental protection, health or safety measure, is expropriatory. ${ }^{224}$

217 Alvarez, supra note 19, at 13.

218 See supra text accompanying notes 45-46.

219 U.S.-Arg. BIT, supra note 37, art. VI(1)

2202004 Model BIT, supra note 194, art. 6(1).

221 See id. Annex B, I 4(a); see also Lévesque, supra note 22, at 286 (noting that the factors to weigh in determining whether a measure constitutes an indirect expropriation are derived from the U.S. Supreme Court's Penn Central decision).

2222004 Model BIT, supra note 194, Annex B, I| 4(b).

223 See, e.g., Gantz, Evolution of FTA Investment Provisions, supra note 22, at 745.

224 For a detailed analysis of the expropriation provision, see id. at 743-46 (discussing analogous language in the U.S.-Chile FTA). See also Lévesque, supra note 22 , at $285-87$. 


\section{Fair and Equitable Treatment}

Consistent with the interpretation issued by the NAFTA Free Trade Commission, ${ }^{225}$ the fair and equitable treatment obligation has been rewritten in the 2004 Model BIT to clarify that customary international law sets a ceiling and not a floor on the standard of treatment that must be accorded. ${ }^{226}$ An annex defines customary international law for this purpose as general and consistent state practice performed out of a sense of legal obligation. ${ }^{227}$ The provision now states that a host state must accord investments treatment consistent with "customary international law, including fair and equitable treatment and full protection and security." 228 For further clarification, it expressly states that these concepts do not require treatment beyond the customary international law standard, and do not create additional substantive rights. ${ }^{229}$ Alvarez has characterized the 2004 model's revision of the fair and equitable treatment standard as "dramatically limit[ing] its scope." ${ }^{230}$ Because the standard is still defined by reference to customary international law, however, other commentators suggest that tribunals may continue to interpret the standard broadly. ${ }^{231}$

In addition to redefining the standard for indirect expropriation, the 2004 Model BIT also incorporates special carve-outs to the expropriation guarantee for certain tax measures and compulsory licensing measures that are otherwise WTO-compliant. See Alvarez, supra note 19, at 10 (discussing 2004 Model BIT Srticles 6(5) and 21(2)).

225 See supra text accompanying note 113.

226 See 2004 Model BIT, supra note 194, art. 5(1)-(2). Also consistent with the NAFTA Law Commission interpretation is a statement that the finding of a breach of another part of the BIT, or of another treaty, does not in itself establish a breach of the fair and equitable treatment obligation. Id. art. 5(3).

227 Id. Annex A. According to Vandevelde, Annex A was written with the Loewen dispute in mind, where the claimant argued that the network of existing BITs are part of customary international law. Annex A was an attempt to refute this argument, at least where treaty practice is not accompanied by independent evidence of opinio juris. VANDEVELDE, INVESTMENT AGREEMENTS, supra note 12 , at 268 . But see Lévesque, supra note 22, at 257-58 (noting that Annex A goes on to inject ambiguity into the definition, by stating that the customary international law minimum standard of treatment refers to "all customary international law principles" that protect the legal rights and interests of aliens).

2282004 Model BIT, supra note 194, art. 5(1) (emphasis added).

229 See id. art. 5(2).

230 Alvarez, supra note 19 , at 9.

231 See Gantz, Evolution of FTA Investment Provisions, supra note 22, at 727; see 


\section{Investor-State Arbitration}

The 2004 Model BIT introduces numerous changes to the investor-state dispute settlement mechanism. Whereas some of these changes were mandated by TPA, others were modeled after NAFTA Chapter $11 . .^{232}$ As discussed above, TPA negotiation objectives included improving the investor-state dispute settlement mechanism by making it more transparent, enabling public input, deterring frivolous investor claims, establishing a mechanism for accepting amicus submissions, and providing for appellate review of arbitral awards. ${ }^{233}$ With the exception of establishing an appellate review mechanism, ${ }^{234}$ the 2004 Model BIT achieves these objectives. ${ }^{235}$ The transparency provisions are particularly significant. Article 29(1) mandates publication not only of all decisions of the tribunal but also of all notices, pleadings, briefs, amicus briefs, and other submissions; Article 29(2) requires the tribunal to conduct hearings open to the public. ${ }^{236}$ These requirements are subject to essential security exceptions and to special procedures that can be invoked at a disputing party's request to protect confidential information. ${ }^{237}$ These provisions significantly enhance the public's ability to follow pending investment disputes, and to study the growing body of investment

also Lévesque, supra note 22, at 261-62.

232 See Gagné \& Morin, supra note 22, at 371.

233 See supra text accompanying notes 185-187.

234 Annex D only requires the treaty parties, within three years after the BIT enters into force, to "consider" whether to establish a mechanism to review investor-state arbitration awards. David Gantz suggests that although potentially beneficial, the legal and practical difficulties associated with establishing an appellate body are sufficiently daunting that the Annex may only be aspirational. David A. Gantz, An Appellate Mechanism for Review of Arbitral Decisions in Investor-State Disputes: Prospects and Challenges, 39 VAND. J. TRANSNAT'L L. 39 (2006).

235 See 2004 Model BIT, supra note 194, arts. 29(1) (requiring the respondent to make available to the public documents, including the notice of intent, pleadings, briefs and any decisions of the tribunal), 29(2) (requiring the tribunal to conduct open hearings), 28(2) (allowing the non-disputing state to make submissions to the arbitral tribunal), 28(4)-(6) (providing an expedited procedure for the tribunal to decide jurisdictional or other preliminary objections of respondent, and allowing the award of costs and attorneys' fees as a sanction for frivolous claims or defenses), 28(3) (granting the tribunal authority to accept and consider amicus submissions).

236 Id. arts. 29(1)-(2).

237 Id. arts. 29(3)-(4). 
arbitration awards. ${ }^{238}$ The transparency requirements have significantly altered expectations of privacy in the investment arbitration context. ${ }^{239}$

Other innovations to the dispute settlement procedure of the 2004 model were influenced by NAFTA Chapter 11. Similar to NAFTA, the 2004 model imposes a three-year limitation period for the submission of claims $\mathrm{s}^{240}$ and requires a claimant to provide ninety days' advance notice of intent to submit a claim to arbitration. ${ }^{241}$ The 2004 model also grants the contracting states authority to issue joint interpretations of the treaty that are binding on the tribunal. ${ }^{242}$ These provisions, although not all mandated by TPA, serve to protect the host state's interests by limiting the investor's power to bring claims and enhancing the state's participation in the dispute settlement process. ${ }^{243}$

\section{Exceptions Clause}

An exceptions clause, also known as a "non-precluded measures" (NPM) clause, is a clause in a BIT specifying certain matters to which the BIT does not apply. ${ }^{244}$ The 2004 Model BIT's revision of the NPM clause was not mandated by TPA but most likely was influenced by Argentina's experience as respondent to investor claims in the aftermath of its financial

238 See, e.g., OECD Investment Committee, Transparency and Third Party Participation in Investor-State Dispute Settlement Procedures, in INTERNATIONAL INVESTMENT LaW: A CHANGING LANDSCAPE: A COMPANION VOLUME TO INTERNATIONAL INVESTMENT PERSPECTIVES (2005) (discussing how investor-state arbitration traditionally has operated confidentially and without public participation, but arguing in favor of greater transparency and public access, subject to certain qualifications and safeguards); cf. Lévesque, supra note 22, at 267-69 (suggesting that EMEs such as India or China may not embrace transparency or public participation in investor-state arbitration to the same degree that the United States and Canada have).

239 See OECD Investment Committee, supra note 238.

240 See 2004 Model BIT, supra note 194, art. 26(1); NAFTA, supra note 2, art. $1116(2)$.

241 See 2004 Model BIT, supra note 194, art. 24(2); NAFTA, supra note 2, art. 1119.

242 See 2004 Model BIT, supra note 194, art. 30(3); NAFTA, supra note 2, art. $1131(2)$.

243 See OECD Investment Committee, supra note 238.

244 NeWCOMBE \& PARADELL, supra note 213, at 482-83. 
crisis. ${ }^{245}$ The U.S.-Argentina BIT, similar to early U.S. model BITs, includes a narrowly-worded NPM clause. Specifically, it provides that the treaty "shall not preclude the application by either Party of measures necessary for the maintenance of public order... or the protection of its own essential security interests." ${ }^{246}$ Although Argentina has invoked this clause to excuse responsibility to foreign investors for the measures it took to stabilize its economy during the 2001-2002 financial crisis, some tribunals have refused to apply it to excuse Argentina's treaty obligations. ${ }^{247}$ Professor Joseph Weiler commented on the narrow scope of traditional exceptions clauses in BITs. ${ }^{248} \mathrm{He}$ contrasted them with the broader scope of the General Agreement

245 See Alvarez, supra note 19, at 8 (noting the impact of Argentina's experience on the 2004 Model BIT).

246 U.S.-Arg. BIT, supra note 38, art. XI. The clause also includes measures necessary to fulfill a party's obligations to maintain international peace or security. Id.

247 For example, in CMS Gas Transmission Co. v. Argentine Republic, the tribunal found that Article XI of the U.S.-Argentina BIT (i) was not self-judging; and (ii) although, in principle a major economic crisis could be found to implicate Argentina's "essential security" interests, Argentina's crisis, although severe, did not precipitate a "total economic and social collapse" and therefore did not provide a basis for excuse. CMS Gas Transmission Co. v. Argentine Rep., ICSID Case No. ARB/01/8, Award, if 373, 355, 359 (May 12, 2005), 14 ICSID Rep. 158 (2009). Although an annulment panel later found that the CMS tribunal had committed a "manifest error of law" by conflating interpretation of Article XI with application of the international law doctrine of necessity, it found that the error was not grounds for annulling the award. CMS Gas Transmission Co. v. Argentine Republic, ICSID Case No. ARB/01/8, Decision on Annulment, ףf1130, 136 (Sept. 25, 2007), 14 ICSID Rep. 251 (2009). More recently, ICSID annulment panels annulled investment arbitration awards against Argentina for an error similar to that found by the CMS annulment panel on grounds that the panel below had manifestly exceeded its powers. See Sempra Energy Int'l v. Argentine Republic, ICSID Case No. ARB/02/16, Decision on Annulment, 223 (Jun. 29, 2010); Enron Creditors Recovery Corp. v. Argentine Republic, ICSID Case No. ARB/01/3, Decision on Annulment (Jul. 30, 2010).

For a discussion of $C M S$ and other decisions interpreting Article XI of the U.S.Argentina BIT in the context of Argentina's financial crisis, see WILLIAM W. BURKEWhite \& ANDREAS von STADEN, State Liability for Investor Harms in Exceptional Circumstances, in LATIN AMERICAN INVESTMENT TREATY ARBITRATION: THE CONTROVERSIES AND CONFLICTS 151-55 (Mary H. Mourra ed. 2008) (describing how, of the four arbitral awards decided by 2007, three of the tribunals construed Article XI as not excusing Argentina's actions in response to the crisis).

248 Joseph H. H. Weiler, The Robert Hudec Lecture, Second Biennial Global Conference of the Society of International Economic Law (July 5, 2010) (notes on file with author). 
on Tariffs and Trade's (GATT) public policy exceptions, ${ }^{249}$ explaining the discrepancy by observing that in the BIT context, negotiators from more powerful, developed countries (who tended to dictate the terms of the treaties) did not imagine that their states would ever be respondents in investor-state disputes; ${ }^{250}$ in contrast, the GATT negotiators likely envisaged their respective states defending before GATT panels and so included a list of public policy exceptions to the treaty. ${ }^{251}$

In contrast to previous BITs, ${ }^{252}$ the 2004 model not only includes specific exceptions for certain financial services and taxation measures, ${ }^{253}$ but also adds language to clarify that the "essential security" exception is self-judging. Article 18(2) now provides that the BIT does not preclude a state from applying measures that it considers necessary to fulfill its obligations relating to protection of its essential security interests. ${ }^{254}$ The addition of the phrase "it considers necessary" makes explicit that

249 Subject to the requirements of its chapeau, GATT art. XX provides a list of general exceptions to the treaty, including: exceptions for certain measures necessary to protect public morals; to protect human, animal or plant life or health; to secure compliance with local laws; and certain measures to conserve natural resources. General Agreement on Tariffs and Trade, arts. XX(a), (b), (d), (g), Oct. 30, 1947, 61 Stat. A-11, 55 U.N.T.S. 194 [hereinafter GATT].

250 Weiler, supra note 248.

251 Id.

252 The inclusion of explicit self-judging language was not unprecedented, however. The U.S.-Russia BIT, concluded in 1992 but not yet in force, included selfjudging language in its "essential security" exception. See NewCOMBE \& PARAdELl, supra note 213 , at 490 . NAFTA also has a national security exception (modeled after GATT art. XXI) that contains self-judging language; see also Alvarez, supra note 19, at 10 n.28, citing NAFTA, supra note 2, art. 2102(10)(b). The scope of the exception, however, is limited to measures relating to the traffic in arms and other implements of war, measures taken in war or other international emergency, and measures relating to the non-proliferation of nuclear devices. NAFTA, supra note 2, art. 2102(1)(b).

253 Article 20 provides an exception for financial services measures adopted for prudential reasons, or to ensure the integrity or stability of the financial system. 2004 Model BIT, supra note 194, art. 20(1). It also provides for special dispute settlement procedures when a state invokes the article as a defense to an investor claim. Id. art. 20(3). Article 21 exempts taxation measures from all BIT obligations except (i) certain performance requirements and (ii) the expropriation guarantee. Id. art. 21. However, any investor bringing an expropriation claim must first submit the matter to competent tax authorities in both countries for a determination of whether the measure constitutes an expropriation. Id.

2542004 Model BIT, supra note 194, art. 18(2) (emphasis added). 
the applicability of the exception is to be judged by the state invoking the exception and not by the tribunal. Although a state invoking such an exception may be subject to objective limitations such as good faith, ${ }^{255}$ the U.S.-Peru TPA (one of the new generation FTAs containing an investment chapter) appears to make the applicability of the "essential security" exception completely non-justiciable. ${ }^{256}$ Alvarez has suggested that this new version of the essential security exception, if construed broadly as suggested by the U.S.-Peru TPA, may render a host state's treaty obligations illusory, acting as a "get-out-of-jail-free card" for any host state that seeks to invoke it. ${ }^{25}$

The new generation of U.S. BITs and FTAs, therefore, represents a fundamental shift in the U.S. approach towards treatybased investment protection, both in its limitations on the substantive obligations of the host state to foreign investors and its introduction of greater transparency and public participation to the investor-state dispute settlement process. This shift in approach can also be seen in the length and detail of the 2004 model relative to previous model BITs. Under the 2004 model, the host state's obligations under the treaty are substantially more qualified, which is a consequence of the increasingly likely prospect that the United States may find itself on the host state side of an investor-state dispute.

D. Claims Under New Generation FTAs: CAFTA-DR and U.S.-Peru TPA

As of yet only one arbitral tribunal, in Railroad Development Corp. v. Republic of Guatemala, ${ }^{258}$ has interpreted the substantive

255 See NewCombe \& PARAdell, supra note 213, at 494 (noting that even where a security exception to a BIT is self-judging, tribunals still generally hold a state to a standard of good faith).

256 See U.S.-Peru Trade Promotion Agreement, U.S.-Peru, art. 22.2 n.2, Apr. 12, 2006 ,

http:/www.ustr.gov/sites/default/files/uploads/agreements/fta/peru/asset_upload_file841 9542.pdf [hereinafter U.S.-Peru TPA], discussed in Alvarez, supra note 19, at 10 n.28 (providing "for greater certainty" that if the essential security exception is invoked in an investor-state dispute settlement proceeding, the tribunal shall find that the exception applies).

257 Alvarez, supra note 19 , at 15.

258 ICSID Case No. ARB/07/23, Award (June 29, 2012). 
obligations of the new generation of U.S. investment agreements. ${ }^{259}$ But several jurisdictional and other preliminary decisions have been issued with respect to claims filed against host states under CAFTA-DR. ${ }^{260}$ Additionally, a request for arbitration was recently filed under the U.S.-Peru TPA. ${ }^{261}$ Table 2 summarizes the nature and status of these claims.

259 See id.

260 Dominican Republic-Central America Free Trade Agreement, Dom. Rep.-Ctr. Am., Aug. 5, 2004, http://www.ustr.gov/trade-agreements/free-trade-agreements/cafta$\mathrm{dr}$-dominican-republic-central-america-fta/final-text [hereinafter CAFTA-DR].

261 Renco Grp., Inc. v. Republic of Peru, Notice of Intent to Commence Arbitration (Dec. 29, 2010), http://italaw.com/documents/RencoGroupVPeru_NOI.pdf. 
Table 2: Claims brought under CAFTA-DR and U.S.-Peru TPA ${ }^{262}$

\begin{tabular}{|l|l|l|l|l|l|}
\hline \multicolumn{1}{|c|}{ Parties } & Tribunal & \multicolumn{1}{|c|}{ Treaty } & \multicolumn{1}{c|}{$\begin{array}{c}\text { Invest. } \\
\text { Sector }\end{array}$} & $\begin{array}{c}\text { Alleged } \\
\text { Treaty } \\
\text { Violations }\end{array}$ & $\begin{array}{c}\text { Status of } \\
\text { Claim } \\
\text { (June 2012) }\end{array}$ \\
\hline $\begin{array}{l}\text { TCW Group, } \\
\text { Inc. v. Dom. } \\
\text { Rep. }^{263}\end{array}$ & UNCITR & CAFTA- & Electricity & MFN, Nat'l & Settled \\
& & DR & distribution & $\begin{array}{l}\text { treatment, } \\
\text { (consent award } \\
\text { FET, 264 } \\
\text { issued July } \\
\text { Expropri- } \\
\text { ation }\end{array}$ & 2009) \\
\hline
\end{tabular}

262 Jarrod Hepburn, As Peruvian Citizens Sue U.S. Mining Investors for Environmental Harms, Mining Company Makes Good on Threat, INV. ARB. RPTR. (May 17, 2011), http://www.iareporter.com/categories/20110305 (last visited Oct. 7, 2012) (subscription required); Luke Eric Peterson, Mining Investor's Lack of Funding Puts CAFTA Arbitration on Ice, INV. ARB. REP. (Dec. 31, 2011), http:/www.iareporter.com/categories/20110305 (subscription required) [hereinafter Peterson, Mining Investors]; Luke Eric Peterson, U.S. Electricity Company Requests Arbitration for Alleged Breaches of CAFTA by Guatemala, INV. ARB. REP. (Nov. 25, 2010), http://www.iareporter.com/categories/20100326_2 (subscription required); Press Release, Renco Group, Inc., Government of Peru's Actions Toward Doe Run Peru Said to Violate Trade Treaty Between United States and Peru (Jan. 5, 2011), http://www.rencogroup.net/press01052011.php.

The chart was compiled by conducting searches for claims brought against parties to the BITs and FTAs referred to in supra notes 204-205. The following websites were consulted: INT'L CENTRE FOR SETTLEMENT OF INV. DISPUTES, http://icsid.worldbank.org/ICSID/Index.jsp; INV. TREATY ARB., http://www.italaw.com; INV. ARB. REP., http://www.iareporter.com (last visited Oct. 7, 2012).

263 TCW Grp., Inc. v. Dom. Republic Notice of Arbitration and Statement of Claim (Dec. 21, 2007), http:/www.italaw.com/sites/default/files/case-documents/ita0832.pdf; TCW Grp., Inc. v. Dom. Rep., Consent Award (July 16, 2009), http:/italaw.com/documents/TD-DRConsentAward_001.PDF.

264 FET stands for fair and equitable treatment. Claimants also alleged violation of the obligation to provide full protection and security, which, along with fair and equitable treatment, is the minimum standard of treatment guaranteed under CAFTA-DR art. 10.5. See CAFTA-DR, supra note 260 , art 10.5 . 


\begin{tabular}{|c|c|c|c|c|c|}
\hline Parties & Tribunal & Treaty & $\begin{array}{l}\text { Invest. } \\
\text { Sector }\end{array}$ & $\begin{array}{c}\text { Alleged } \\
\text { Treaty } \\
\text { Violations }\end{array}$ & $\begin{array}{c}\text { Status of } \\
\text { Claim } \\
\text { (June 2012) }\end{array}$ \\
\hline $\begin{array}{l}\text { Commerce } \\
\text { Group Corp. } \\
\text { v. Rep. of El } \\
\text { Salvador }\end{array}$ & ICSID & $\begin{array}{l}\text { CAFTA- } \\
\text { DR }\end{array}$ & Mining & $\begin{array}{l}\text { MFN, Nat'l } \\
\text { treatment, } \\
\text { FET }\end{array}$ & $\begin{array}{l}\text { Dismissed for } \\
\text { lack of juris- } \\
\text { diction; } \\
\text { annulment } \\
\text { proceeding } \\
\text { stayed Dec. } \\
2011\end{array}$ \\
\hline $\begin{array}{l}\text { Railroad } \\
\text { Dev.Corp. v. } \\
\text { Rep. of } \\
\text { Guat. }^{266}\end{array}$ & ICSID & $\begin{array}{l}\text { CAFTA- } \\
\text { DR }\end{array}$ & Railway & $\begin{array}{l}\text { Nat'l } \\
\text { treatment, } \\
\text { FET, Expro- } \\
\text { priation }\end{array}$ & $\begin{array}{l}\text { Award issued } \\
\text { June } 2012 \text {, } \\
\text { finding breach } \\
\text { of FET and } \\
\text { awarding RDC } \\
\text { approx. } \\
\$ 11.3 \text { million }\end{array}$ \\
\hline $\begin{array}{l}\text { Pac Rim } \\
\text { Cayman LLC } \\
\text { v. Rep. of El } \\
\text { Salvador }^{267}\end{array}$ & ICSID & $\begin{array}{l}\text { CAFTA- } \\
\text { DR }\end{array}$ & Mining & $\begin{array}{l}\text { MFN, Nat'l } \\
\text { treatment, } \\
\text { FET, Expro- } \\
\text { priation }\end{array}$ & $\begin{array}{l}\text { Pending (juris- } \\
\text { dictional } \\
\text { award issued } \\
\text { June } 2012 \\
\text { dismissing } \\
\text { CAFTA-DR } \\
\text { claims) }\end{array}$ \\
\hline
\end{tabular}

265 Commerce Grp. Corp. v. Republic of El Sal., ICSID Case No. ARB/09/17, Notice of Arbitration (July 2, 2009); Commerce Grp. Corp. v. Republic of El Sal., ICSID Case No. ARB/09/17, Award (Mar. 14, 2011).

266 Request for Institution of Arbitration Proceedings, R.R. Dev. Corp. v. Republic of Guat., ICSID Case No. ARB/07/23 (June 14, 2007), http://dace.mineco.gob.gt/dacepdf/doc3exp16dace07.pdf [hereinafter Request for Arbitration, R.R. Dev. Corp.]; R.R. Dev. Corp. v. Republic of Guat., ICSID Case No. ARB/07/23, Award (June 29, 2012).

267 Pac Rim Cayman LLC v. Republic of El Sal., ICSID Case No. ARB/09/12, Notice of Arbitration (Apr. 30, 2009); Pac Rim Cayman LLC v. Republic of El Sal., ICSID Case No. ARB/09/12, Decision on the Respondent's Jurisdictional Objections (June 1, 2012). 


\begin{tabular}{|c|c|c|c|c|c|}
\hline Parties & Tribunal & Treaty & $\begin{array}{l}\text { Invest. } \\
\text { Sector }\end{array}$ & $\begin{array}{c}\text { Alleged } \\
\text { Treaty } \\
\text { Violations }\end{array}$ & $\begin{array}{c}\text { Status of } \\
\text { Claim } \\
\text { (June 2012) }\end{array}$ \\
\hline $\begin{array}{l}\text { TECO Guat. } \\
\text { Holdings } \\
\text { LLC v. Rep. } \\
\text { of Guat. }{ }^{268}\end{array}$ & ICSID & $\begin{array}{l}\text { CAFTA- } \\
\text { DR }\end{array}$ & $\begin{array}{l}\text { Electricity } \\
\text { distribution }\end{array}$ & Unknown & Pending \\
\hline $\begin{array}{l}\text { Renco } \\
\text { Group, Inc. } \\
\text { v. Rep. of } \\
\text { Peru }^{269}\end{array}$ & $\begin{array}{l}\text { UNCITR } \\
\text { AL }\end{array}$ & $\begin{array}{l}\text { U.S.- } \\
\text { Peru } \\
\text { TPA }\end{array}$ & Mining & $\begin{array}{l}\text { National } \\
\text { treatment, } \\
\text { FET, } \\
\text { Expro- } \\
\text { priation }\end{array}$ & Pending \\
\hline
\end{tabular}

Two disputes brought against El Salvador under CAFTA-DR, Commerce Group Corp. v. Republic of El Salvador and Pac Rim Cayman LLC v. Republic of El Salvador, show how the procedural innovations in CAFTA-DR have altered the dynamics of the investor-state arbitration process. ${ }^{270}$ Commerce Group illustrates the use of CAFTA-DR's expedited procedure to decide preliminary objections. ${ }^{271}$ Shortly after the tribunal was constituted, El Salvador filed a preliminary objection ${ }^{272}$ asserting that Commerce Group had allowed domestic court proceedings in El Salvador to continue with respect to the same measure that it challenged in arbitration, rendering the request for arbitration invalid pursuant to CAFTA-DR's waiver provision. ${ }^{273}$ The

268 TECO Guat. Holdings LLC v. Republic of Guat., ICSID Case No. ARB/10/23, Procedural Details.

269 Claimant's Notice of Intent to Commence Arbitration, Renco Grp., Inc. v. Republic of Peru (Dec. 29, 2010), available at http://italaw.com/documents/RencoGroupVPeru_NOI.pdf.

270 Commerce Grp., ICSID Case No. ARB 09/17, Award; Pac Rim Cayman, ICSID Case No. ARB/09/12, Decision on Respondent's Jurisdictional Objections.

271 See Commerce Grp., ICSID Case No. ARB/09/17, Award, ๆ 34.

272 Similar to the 2004 Model BIT, paragraphs four and five of CAFTA-DR's art. 10.20 allow the respondent to raise a preliminary objection to claimant's claim, and provide an expedited procedure for the tribunal to decide such objection. See 2004 Model BIT, supra note 194.

273 See Commerce Grp., ICSID Case No. ARB/09/17, Award, 1 1 33, 66. CAFTADR's waiver requirement conditions an investor-state arbitration claim on the claimant submitting a written waiver of its right to continue any proceeding before a local court or tribunal with respect to the measure challenged under the treaty. CAFTA-DR, supra 
tribunal ultimately agreed and dismissed the claim for lack of jurisdiction, ${ }^{274}$ relying in part on briefs submitted to the tribunal by other CAFTA-DR states in favor of El Salvador's position. ${ }^{275}$ Commerce Group filed a request with ICSID to annul the tribunal's award, but the request was stayed for failure to pay an advance on costs. ${ }^{276}$

Pac Rim demonstrates how CAFTA-DR's rules regarding transparency and public participation facilitate the involvement of NGOs and other interested parties in the investor-state dispute settlement process. ${ }^{277}$ First, CAFTA-DR's transparency requirement ${ }^{278}$ greatly enhance the availability of information regarding Pac Rim and other CAFTA-DR disputes. ${ }^{279}$ In May

note 260 , art. $10.18(2)$ (b). The tribunal interpreted the waiver requirement as requiring the investor not only to submit the written waiver but also to discontinue such domestic proceedings. Commerce Grp., ICSID Case No. ARB/09/17, Award, \ 80.

274 See Commerce Grp., ICSID Case No. ARB/09/17, Award, ๆ 115.

275 See id. 19 81-82 (citing the submissions of Costa Rica and Nicaragua pursuant to CAFTA-DR art. 10.20(2)). The tribunal found that the investor's claim was not frivolous, such that Commerce Group was required to bear only half of the costs and its own legal fees associated with the proceeding. Id. \\{ 137-39.

276 See Peterson, Mining Investors, supra note 262.

277 See Pac Rim Cayman LLC v. Republic of El Sal., ICSID Case No. ARB/09/12, Public Hearing (May 2-4, 2011), https://icsid.worldbank.org/ICSID/FrontServlet? requestType $=$ CasesRH\&actionVal $=$ OpenPage $\&$ Page $T y p e=$ AnnouncementsFrame $\&$ Fro mPage $=$ Announcements\&pageName $=$ Announcement 89 [hereinafter Public Hearing, Pac Rim Cayman LLC].

278 CAFTA-DR, supra note 260, art. 10.21 (strongly resembling 2004 Model BIT, supra note 194, art. 29).

279 CAFTA-DR art. 10.21(1) imposes the document publication requirement on respondent. Some documents have not been made promptly and publicly available. For example, although ICSID registered TECO's claim against Guatemala in November 2010, as of August 2011, it appears that neither the notice of intent nor the pleadings were yet available online. See TECO Guat. Holdings LLC v. Republic of Guat., ICSID Case No. ARB/10/23, Procedural Details.

However, relevant documents pertaining to concluded and pending CAFTA-DR claims generally are publicly available on the internet. The Investment Treaty Arbitration website provides links to such documents, including documentation pertaining to all of the disputes listed in Table 2 (with the exception of TECO $v$. Guatemala). See INV. TREATY ARB., http://www.italaw.com (last visited Oct. 7, 2012). As for Pac Rim, substantially all of the documentation required by Article 10.21(1) appears to be available online, including the notice of intent, notice of arbitration, respondent's preliminary objections and responses thereto, expert opinions, witness statements, the tribunal's decision on preliminary objections, respondent's objections to jurisdiction, and the application of amici to participate in the proceeding. See id. 
2011, ICSID recorded the Pac Rim tribunal's hearing on respondent's preliminary objections to jurisdiction, which ICSID made available to the public for streaming on its website in English and Spanish. ${ }^{280}$

Additionally, as a dispute implicating the public interest in environmental protection, Pac Rim attracted the attention of several NGOs, which successfully petitioned the tribunal for leave to submit an amicus brief. ${ }^{281}$ Pac Rim sought compensation for breaches of CAFTA-DR's fair and equitable treatment and nondiscrimination obligations, and of the guarantee against expropriation. ${ }^{282}$ It alleged that the Salvadorian government induced it to spend millions of dollars to undertake gold and silver mining exploration activities and, years later, refused to grant it an environmental permit or conclude the mining concession. ${ }^{283}$ According to amici briefs, however, the government's reluctance to issue new mining permits was in response to intense public opposition to metals mining and to legitimate concerns raised regarding the negative environmental and social effects of Pac Rim's exploratory activities. ${ }^{284}$ A group of eight local NGOs, operating under the banner "La Mesa," 285 submitted an application for permission to proceed as amici curiae in the arbitration, as allowed under CAFTA-DR. ${ }^{286}$ The tribunal granted La Mesa

280 See Public Hearing, Pac Rim Cayman LLC, supra note 277.

281 See, e.g., Application for Permission to Proceed as Amici Curiae at 6, Pac Rim Cayman LLC v. Republic of El Sal., ICSID Case No. ARB/09/12 (Mar. 2, 2001) [hereinafter Application to Proceed as Amici Curiae, Pac Rim Cayman LLC], available at http://italaw.com/documents/PAC_RIM_Amicus_2Marl1_Eng.pdf.

282 CAFTA-DR, supra note 260, arts. 10.3 (national treatment), 10.4 (most-favored nation treatment), 10.5 (fair and equitable treatment), 10.7 (expropriation). Substantively, these provisions are almost identical to the analogous provisions of the 2004 Model BIT, except that CAFTA-DR makes some adjustments to the standard for compensation to investors for loss resulting from armed conflict or civil strife. See 2004 Model BIT, supra note 194, arts. 3-6.

283 Pac Rim Cayman LLC v. Republic of El Sal., ICSID Case No. ARB/09/12, Notice of Arbitration, 19 7-9 (Apr. 30, 2009).

284 Application to Proceed as Amici Curiae, Pac Rim Cayman LLC, supra note 281 , at 6 .

285 La Mesa is short for Mesa Nacional Frente a la Minería Metálica de El Salvador (National Roundtable Against Metallic Mining). Id. at 1.

286 CAFTA-DR, like the 2004 Model BIT, authorizes the arbitral tribunal to consider and accept amicus submissions from non-disputing parties. CAFTA-DR, supra note 260, art. 10.20(3); see also 2004 Model BIT, supra note 194, at art. 28(3). 
permission to file an amicus submission on the condition that the submission be edited to address only the jurisdictional issues currently before the tribunal. ${ }^{287}$

A different CAFTA-DR dispute, $R D C v$. Guatemala, provided a tribunal with the first opportunity to interpret CAFTA-DR's guarantees against indirect expropriation and of fair and equitable treatment. ${ }^{288}$ In 1997, RDC won a public bid for a fifty-year concession to rebuild and operate Guatemala's narrow gauge railroad system. ${ }^{289}$ The concession included a right of way contract and a rail equipment lease contract. ${ }^{290}$ After operating the concession for seven years, RDC's Guatemalan subsidiary filed arbitration claims against the government for breach of contract, alleging failure to adhere to certain obligations related to the concession. $^{291}$ Fourteen months later, Guatemala's president issued a decree declaring the rail equipment lease contract "injurious to the interests of the state" and void. ${ }^{292} \mathrm{RDC}$ alleged that the decree was issued in order to force RDC's subsidiary to withdraw from the arbitration and ultimately to redistribute RDC's interest in the concession to other investors. ${ }^{293}$ The tribunal rejected RDC's claims of expropriation and discriminatory treatment. ${ }^{294}$ It agreed, however, that the presidential decree was "arbitrary, grossly unfair, and unjust," thereby breaching CAFTADR Article 10.5, the minimum standard of treatment (or fair and equitable treatment) provision. ${ }^{295}$ The tribunal took notice of the third-party submissions of the United States, El Salvador, and

287 Pac Rim Cayman LLC v. Republic of El Sal., ICSID Case No. ARB/09/12, Procedural Order No. 8 (Mar. 23, 2011), http://italaw.com/documents/ PacRim_ElSalvador_ProceduralOrderNo8.pdf. Although the brief attached to La Mesa's application primarily was directed to the merits of the dispute, La Mesa's arguments on the merits will presumably be re-submitted for consideration during the merits phase if there is one.

288 See Request for of Arbitration, R.R. Dev. Corp., supra note 266, ๆף 54-69.

289 See id. १ๆ $27-29$.

290 Id. $\mid 30$.

291 Id. $\mid$ | 34.

292 Id. ๆๆ $39-40$.

293 Id. ๆ 40.

294 R.R. Dev. Corp. v. Republic of Guat., ICSID Case No. ARB/07/23, Award, ๆ. 152-55 (June 29, 2012).

295 Id. $\uparrow 235$. 
Honduras, which emphasized that Article 10.5 should be interpreted as requiring a minimum standard of treatment under customary international law, based on state practice and opinio juris. ${ }^{296}$ At the same time, the tribunal found that customary international law is not static; rather, it is a developing standard. ${ }^{297}$

Between Pac Rim and RDC, the merits of the Pac Rim dispute attracted more public attention since it raised more difficult questions of how to balance host state regulatory interests against investment protection. ${ }^{298} R D C$, in contrast, involved a relatively uncontroversial challenge to a government decree nullifying a crucial contract underlying RDC's investment. ${ }^{299}$ In June 2012, however, the Pac Rim tribunal dismissed the investor's CAFTADR claims on the basis of the treaty's denial of benefits clause, ${ }^{300}$ finding that Pac Rim was a shell holding company under Canadian ownership with no substantial business activities in the United States. ${ }^{301}$ The tribunal, however, did allow Pac Rim's Salvadoran investment law claims to proceed to the merits. ${ }^{302}$

To conclude, application and interpretation of the new generation of U.S. FTAs and BITs is still a work in progress. The controversial claim that Philip Morris International (PMI) filed against Uruguay ${ }^{303}$ highlights what is at stake with the shift in U.S. BIT practice. In February 2010, PMI filed a request for arbitration, alleging that tobacco packaging requirements (mandating the use of graphic photos and very large printed warnings), adopted by Uruguay to warn of the health effects of

296 Id. ๆๆ 207-11.

297 Id. $\$ 218$.

298 The dispute has been reported in the New York Times. See Randal C. Archibold, First a Gold Rush, Then the Lawyers, N.Y. TIMES, June 26, 2011, at A6 (discussing the controversy surrounding Pac Rim's investment arbitration claim).

299 See Request for Arbitration, R.R. Dev. Corp., supra note 266, at 15-20.

300 See CAFTA-DR, supra note 260, art. 10.12(2) (allowing a party to deny treaty benefits to an investor if persons of a non-CAFTA-DR state own or control the enterprise and the investor has no "substantial business activities" in the party's territory).

301 Pac Rim Cayman LLC v. Republic of El Sal., ICSID Case No. ARB/09/12, Decision on the Respondent's Jurisdictional Objections, ๆף 4.68, 4.82 (June 1, 2012).

302 Id. $\uparrow 5.48$.

303 Request for Arbitration, Philip Morris Brand Sàrl, et al. v. Oriental Republic of Unu., ICSID Case. No. ARB/10/7, \$1 33-42, 77 (Feb. 19, 2010) [hereinafter Request for Arbitration, Philip Morris], available at http://www.italaw.com/documents/PMIUruguayNoA.pdf. 
smoking, violate the 1988 Switzerland-Uruguay BIT. ${ }^{304}$ It may be that applicability of the Switzerland-Uruguay BIT to the dispute is a mere fortuity; the U.S.-based Altria Group's spin-off of PMI in 2008 was driven by numerous factors, including avoiding FDA regulation of tobacco products. $^{305}$ Nonetheless, a significant benefit to PMI of the corporate restructuring was that it became a Swiss investor, and, as such, could invoke the protections of the Switzerland-Uruguay BIT in its dispute with Uruguay (as opposed to the U.S.-Uruguay BIT, concluded on the basis of the 2004 Model BIT). ${ }^{306}$ PMI alleges that the packaging requirements constitute an indirect expropriation of its trademark rights. ${ }^{307}$ PMI also argues that the measures violate the fair and equitable treatment standard because they are inconsistent with its "legitimate expectations" of a stable regulatory framework and with the TRIPs Agreement. ${ }^{308}$ These arguments would be quite difficult to make under the U.S.-Uruguay BIT, which limits the fair and equitable treatment standard and clarifies that most nondiscriminatory health-related regulation is not expropriatory. ${ }^{309}$

304 Id. One of the claimants is Abal Hermanos, S.A., a Unuguay-based company that markets PMI products in Uruguay and is owned by a PMI affiliate. Id. at 14-15. For a discussion of PMI's investment arbitration claim, see Matthew C. Porterfield \& Christopher R. Barnes, Philip Morris v. Uruguay on cigarette branding: Will InvestorState Arbitration Send Restrictions on Tobacco Marketing up in Smoke?, INV. TREATY NEwS, at 3-6 (July 12, 2011), http:/www.iisd.org/itn/2011/07/12/philip-morris-vuruguay-will-investor-state-arbitration-send-restrictions-on-tobacco-marketing-up-insmoke/; see also Luke Eric Peterson, Uruguay: Philip Morris Files First-Known Investment Treaty Claim Against Tobacco Regulations, INV. ARB. REP. (Mar. 3, 2010), http://www.iareporter.com/articles/20100303 (last visited Oct. 7, 2011) (subscription required).

The BIT that PMI is invoking is the Agreement on the Reciprocal Promotion and Protection of Investments, Switz.-Uru., Oct. 7, 1988. For a reference to the SwitzerlandUruguay BIT, see Request for Arbitration, Philip Morris, supra note 304, I 1 n. 1 (full text of the Switzerland-Uruguay BIT is available in Spanish at http://www.sice.oas.org/Investment/BITSbyCountry/BITs/URU_France_s.pdf).

305 See Ruthie Ackerman, Altria Seals Spinoff Deal, Forbes.COM (Jan. 30, 2008), http://www.forbes.com/2008/01/30/altria-philipmorris-cigarettes-markets-equity-cx-ra0130markets24.html.

306 See Porterfield \& Barnes, supra note 304, at 7.

307 Request for Arbitration, Philip Morris, supra note 304, $\rceil 83$.

308 Id. ๆ⿻ 84-85.

309 The U.S.-Uruguay BIT's provisions on fair and equitable treatment and expropriation are identical to those in the 2004 model. Treaty Concerning the Encouragement and Reciprocal Protection of Investment, U.S.-Uru., arts. 4, 5 \& 


\section{III.EMEs as Capital Exporters and Their Approach to BITs}

\section{A. EMEs as Capital Exporters}

Twenty years ago, the United Nations Centre on Transnational Corporations observed that investors from the United States and the European Community no longer dominated global outward FDI (OFDI) stocks and flows. ${ }^{310}$ In other words, the preexisting bipolar $^{311}$ pattern of OFDI had been replaced with the "triad" of the United States, the European Community, and Japan. ${ }^{312}$ Today, scholars Persephone Economou and Karl Sauvant note that this characterization needs to be revisited because EMEs as a group have replaced Japan as the third pole in the triad. ${ }^{313}$ In particular, the EMEs' share of global OFDI stocks ${ }^{314}$ increased to $16 \%$ in 2009 , and their share of OFDI flows ${ }^{315}$ increased to $25 \%$ from

Annexes A, B, Nov. 4, 2005, available at http://www.ustr.gov/sites/default/files/ uploads/agreements/bit/asset_upload_file748_9005.pdf. For a discussion of the 2004 model's revisions to the fair and equitable treatment and indirect expropriation standards, see supra notes 224-230 and accompanying text.

$310 \mathrm{See}$ U.N. Ctr. on Transnat'l Corp., Salient Features and Trends in Foreign Direct Investment, at 70, U.N. Doc ST/CTC/14 (1983).

311 To qualify as a "pole," a country or group of countries must account for at least ten percent of global OFDI stocks or flows. Economou \& Sauvant, supra note 23.

312 U.N. Ctr. on Transnat'l Corp., World Investment Rep. 1991: The Triad in Foreign Direct Investment, U.N. Doc. No. ST/CTC/118 (Aug. 1991), cited in Economou \& Sauvant, supra note 23 , at n.i.

313 Economou \& Sauvant, supra note 23.

314 FDI stock is defined as "the value of the share of capital and reserves (including retained profits) attributable to the parent enterprise, plus the net indebtedness of affiliates to their parent enterprises." U.N. Conference on Trade and Development, Notes on Inward and Outward Foreign Direct Investment Stock, Annual, 1980-2011 [hereinafter U.N. Conference on Trade and Development, Notes], available at http://unctadstat.unctad.org/TableViewer/tableView.aspx?ReportId=89 (last visited Oct. 7, 2012).

FDI is defined as "an investment involving a long-term relationship and reflecting a lasting interest in and control by a resident entity in one country (foreign direct investor or parent enterprise) of an enterprise resident in a different economy (FDI enterprise)." Id.

315 FDI outflows are defined as capital provided (either directly or through other related enterprises) by a foreign direct investor to a FDI enterprise. FDI includes three components: equity capital, reinvested earnings, and intra-company loans. U.N. Conference on Trade and Development, Notes on Inward and Outward Foreign Direct Investment Flows, Annual, 1970-2011, http://unctadstat.unctad.org/TableViewer/ tableView.aspx?ReportId=88 (last visited Oct. 7, 2012). 
2007 to 2009..$^{316}$ Although EMEs-defined to include any economy that is not a "developed economy" 317 - are a broad and diverse group of countries, the vast majority of outward FDI comes from the top twenty EME capital-exporters. ${ }^{318}$ Graph 1 shows the OFDI stocks of the ten most significant capitalexporting EMEs as of 2010, compared with their OFDI stocks in 2000. It demonstrates that, as of 2010, Russian companies had invested close to half a trillion U.S. dollars in companies abroad. Indian companies, which had invested less than $\$ 2$ billion abroad by 2000 , within ten years increased their OFDI stocks forty-sixfold, to over $\$ 92$ billion, within ten years.

316 Economou \& Sauvant, supra note 23.

317 See supra note 23 (defining EMEs).

318 Twenty EMEs accounted for 85\% of OFDI from all EMEs from 2005 to 2009 (excluding tax havens). Id. 
Graph 1: EMEs with Largest OFDI Stocks (USD billions) ${ }^{319}$

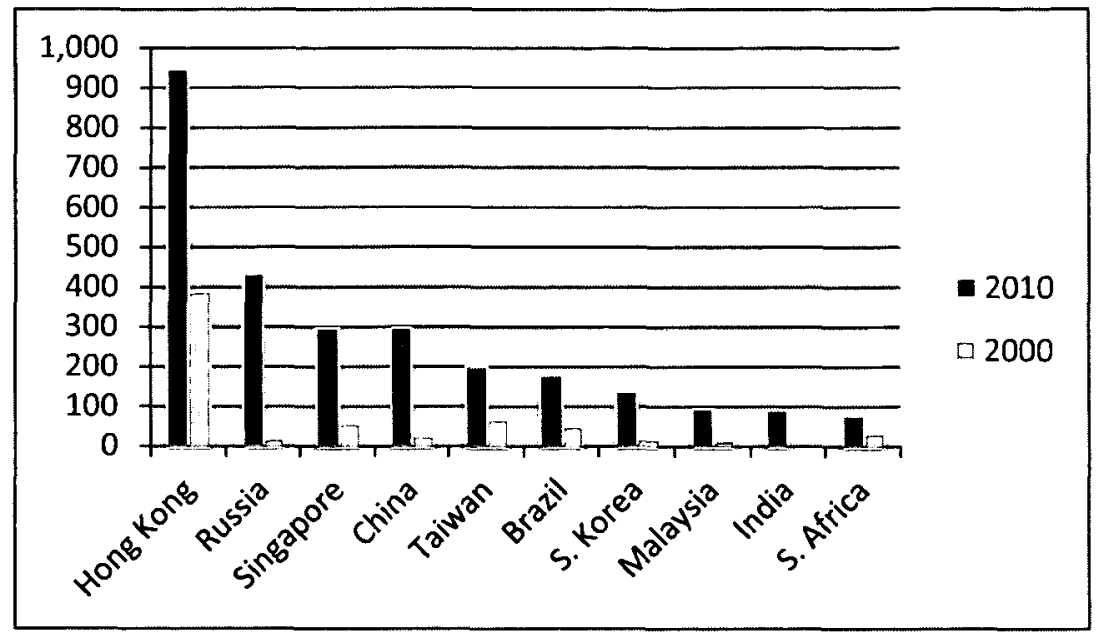

EMEs as a group constitute a significant and rapidly growing source of OFDI. However, a relatively limited subset of EMEs, including Brazil, Russia, India, and China (the BRICs) ${ }^{320}$ and several others, account for most of this investment. Six of these economies (Hong Kong, China, Russia, Singapore, Korea, and

319 U.N. Conference on Trade and Development World Investment Report 2011: Non-Equity Modes of International Production and Development, Annex tbl.1.2, U.N. Doc. UNCTAD/WIR/2011 (July 21, 2011) [hereinafter UNCTAD Report 2011). Tax havens British Virgin Islands and Cayman Islands are excluded from the graph. The data on China excludes OFDI from Hong Kong, Macao, and Taiwan. The data on OFDI from China and Hong Kong may be inflated, as the data do not exclude FDI that is exported from China to Hong Kong and Macao only to be "round-tripped" back into China. Economou \& Sauvant, supra note 23, at n.iv. The data on Russia may be inflated for a similar reason: it does not exclude FDI that is "round-tripped" back to Russia through a haven such as Cyprus or the Netherlands. Alexey Kuznetsov, Outward FDI from Russia and its Policy Context, Update 2011, Columbia FDI ProfiLes 2-3 (Aug. 2, 2011), http://www.vcc.columbia.edu/files/vale/documents/ Profile_Russia_OFDI_-_2_August_2011_FINAL.pdf.

320 In 2003, the investment banking firm Goldman Sachs issued a provocative report predicting that by the year 2040, the economies of Brazil, Russia, India, and China may together surpass in U.S. dollar terms those of the G6 (United States, United Kingdom, Germany, Japan, France, and Italy). Dominic Wilson and Roopa Purushothaman, Dreaming with BRICs: The Path to 2050, Goldman Sachs Global ECONOMICS PAPER No. 99 (Oct. 2003), available at http://www.goldmansachs.com/ourthinking/topics/brics/brics-reports-pdfs/brics-dream.pdf. 
India) were among the top twenty capital-exporting economies worldwide (in terms of global FDI outflows) in 2010. ${ }^{321}$ Another six of these economies (China, Hong Kong, Brazil, Russia, Singapore, and India) were also among the top fifteen recipients of FDI inflows worldwide in 2010.322 The following section describes the BIT practice of the most significant EME capital exporters, with a particular focus on the BRICs.

\section{B. BIT Practice of EME Capital Exporters}

\section{Generally}

Table 3 provides general information regarding the BIT practice of the capital-exporting countries featured in Graph 1 above. Although they are significant exporters of FDI, Taiwan and Hong Kong are not included in the table because these economies' statuses in relation to China uniquely affect their respective treaty practices. ${ }^{323}$

321 UNCTAD Report 2011, supra note 319, at 9 fig.I.9.

322 Id. at 4 fig.I. 4 .

323 Neither Taiwan (the Republic of China or ROC) nor China (the People's Republic of China or PRC) claim to be separate countries, but rather, both claim to be sovereign of both territories. In 1970, the United Nations ordered that the ROC's seat be transferred to the PRC; in 1979, the United States established full diplomatic relations with the PRC. See N.Y. Chinese TV Programs, Inc. v. U.E. Enter., Inc., 954 F.2d 847, 850 (2d Cir. 1992) (discussing the history of the ROC's sovereign status). Since all but a few states recognize the PRC as sovereign of China, Taiwan has concluded relatively few BITs. See U.N. Conference on TRADE AND DeV., Total Number of Bilateral Investment Agreements Concluded: Taiwan Province of China (June 1, 2012), http://archive.unctad.org/sections/dite_pcbb/docs/bits_taiwan.pdf (last visited Oct. 7, 2012) (listing 16 BITs in force).

As a special administrative region of China since 1997, Hong Kong has been granted certain treaty-making authority by the PRC government, and Hong Kong has concluded a number of BITs under that authority. See Zeng Huaqun, Initiative and Implications of Hong Kong's Bilateral Investment Treaties, 11(5) J. WORLD INV. \& TRADE $669,672-73,679$ tbl.1 (2010). There remains the possibility, however, that as a region within the territory of China, Hong Kong investors, at least those with Chinese nationality, might also be entitled to invoke the protections of China's BITs and FTAs. In Tza Yap Shum v. Republic of Peru, the tribunal found that a Chinese national who had resided in Hong Kong since 1972 was entitled to invoke the protections of the ChinaPeru BIT. The tribunal observed that there is nothing in the treaty text that excludes Hong Kong residents from the scope of application of the treaty. Tza Yap Shum v. Republic of Peru, ICSID Case No. ARB/07/6, Decision on Jurisdiction and Competence, ๆๆ 71-74, 76 (June 19, 2009). 
Table 3: BITs and FTAs Concluded by Significant CapitalExporting EMEs

\begin{tabular}{|l|c|c|c|}
\hline \multicolumn{1}{|c|}{ Country } & BITs concluded & B24 & $\begin{array}{c}\text { Estimated FTAs } \\
\text { with investment } \\
\text { chapters in force (as } \\
\text { of 2011) }^{326}\end{array}$ \\
\hline Russia & 71 & 51 & $0^{327}$ \\
\hline China & 128 & 101 & 6 \\
\hline Singapore & 41 & 35 & 15 \\
\hline Brazil & 14 & 0 & $0^{328}$ \\
\hline South Korea & 90 & 82 & 5 \\
\hline India & 83 & 67 & 4 \\
\hline Malaysia & 67 & 49 & 6 \\
\hline South Africa & 46 & 23 & $0^{329}$ \\
\hline
\end{tabular}

324 U.N. CONFERENCE ON TRADE AND DEVELOPMENT, supra note 323.

$325 \mathrm{Id}$.

326 The WTO maintains a searchable database of FTAs in force based on notifications it receives from WTO members. The database indicates which of these agreements covers investment protection. See World Trade OrG., Regional Trade AGREEMENTS INFORMATION SYSTEM, http://rtais.wto.org/UI/PublicMaintain RTAHome.aspx (last visited Oct. 7, 2012). However, not all of the agreements listed on the database have been indexed by topic. Additionally, although the website may list an FTA as covering investment, the FTA may not provide the kinds of specific investment protection commitments that are found in a BIT. For these reasons, the table provides only an estimate of the number of FTAs with investment chapters in force.

327 As of 2011, Russia was not yet a WTO member. Russia concluded FTAs with other CIS countries following the break-up of the Soviet Union and concluded agreements with Belarus, Kazakhstan, and the Kyrgyz Republic providing for formation of a customs union. These agreements, however, do not appear to address investment protection. WTO Working Party on the Accession of the Russian Federation, Information on the Treatment Provided under Preferential Agreements, भी 1-2, WT/ACC/RUS/21 (Nov. 21, 1997).

328 Although the Colonia and Buenos Aires Protocols were concluded in 1994 to provide BIT-like protections to foreign investors, they are not yet in force. See Protocolo de Colonia para a Promoção e a Proteção Recíproca de Investimentos no MERCOSUL [Protocol of Colonia for the Promotion and Reciprocal Protection of Investment within MERCOSUR], Aug. 5, 1994, available at http://www.sice.oas.org/ Trade/MRCSR/colonia/pcolonia_p.asp (showing status of protocol); Noah D. Rubins, Investment Arbitration in Brazil, 4 J. WORLD INV. 1071, 1088-90 (2003) (describing MERCOSUR and the significance of the protocols).

329 Although the WTO website lists the EFTA-SACU FTA (an FTA among the 
Table 3 shows that, of the largest capital-exporting EMEs, all but one have numerous BITs and FTAs in force. Indeed, most of these countries have a number of investment protection agreements in force comparable to or greater than that of the United States. ${ }^{330}$ The notable exception in Graph 1 is Brazil. It is the only country listed that has no investment protection agreements in force. ${ }^{331}$ Brazil's situation is discussed in more detail below. ${ }^{332}$

Of course, the data in Table 3 do not explain why most of the largest capital-exporting EMEs conclude BITs. The traditional explanation as to why EMEs conclude BITs (attracting foreign investment) ${ }^{333}$ may continue to play a role. Additionally, in recent decades, most EMEs have undergone profound economic reforms that have generated domestic pressures to improve their investment climates, to which governments respond, in part, by negotiating BITs and FTAs. ${ }^{334}$ But it is likely that an emerging factor behind EME activity, with respect to BITs and FTAs, is the significant and recent increase of OFDI by EME investors and, consequently, the growing interest on the part of EME governments in protecting their investors abroad.

\section{BRICs}

\section{a. China}

With over 100 BITs currently in force, China has one of the

European Free Trade Association states and the states of the Southern Africa Customs Union) as covering investment, the agreement contains no specific investment guarantees. See WORLD TRADE ORG., supra note 326.

330 As of 2012, the United States has 48 BITs in force. See Bilateral Investment Treaties, USTR, http://www.ustr.gov/trade-agreements/bilateral-investment-treaties (last visited Oct. 18, 2012) (providing a link to "Bilateral Investment Treaties Currently in Force (from the Trade Compliance Center)" that lists 48 BITs). Though the U.S.-Bolivia BIT was terminated in June 2012, this BIT is included in this number as it will continue to apply to covered investments made prior to termination. BITs and Related Agreements, supra note 197. The United States also currently has 11 FTAs with investment chapters in force. See USTR, Free Trade Agreements, supra note 204.

331 WORLD TRADE ORG., supra note 326.

332 See infra notes 382-404 and accompanying text.

333 See Echandi, supra note 53, at 5-6.

334 Id. at 6. 
largest BIT programs in the world. ${ }^{335}$ In contrast to its proinvestor approach to BITs and FTAs today, China's initial BIT practice in the 1980s was relatively conservative, especially with respect to investor-state dispute settlement. ${ }^{336}$ Until the late 1990s, Chinese BITs, if they allowed for arbitration of investor-state disputes at all, ${ }^{337}$ only provided for the arbitration of disputes "involving the amount of compensation for expropriation." 338 Consistent with this restrictive jurisdictional approach, when China acceded to the ICSID Convention in 1993, it notified ICSID that it would only consider submitting "disputes over compensation resulting from expropriation and nationalization" to ICSID jurisdiction. ${ }^{339}$

Beginning around 1998, China liberalized its approach, concluding BITs with broad investor-state dispute settlement clauses. $^{340}$ China's current model BIT provides for ICSID

335 As of the end of 2008, China was second only to Germany worldwide in terms of the number of BITs it had concluded. U.N. Conference on Trade and Development, Recent Developments in International Investment Agreements (2008-June 2009), 3 IIA MONITOR at 1, 3 fig.2 (2009) [hereinafter UNCTAD, Recent Developments], available at http://unctad.org/en/Docs/webdiaeia20098_en.pdf.

336 See Chinese Model BIT Version I, art. 9(3), in Norah Gallagher \& WenhuA Shan, Chinese Investment Treaties: Policies and Practice, at Appendix II (2009); Chinese Model BIT Version II, art. 9(3), in id. at Appendix III.

337 A few early Chinese BITs did not provide at all for arbitration of investor-state disputes. See Elodie Dulac \& John Savage, The Asia Pacific Arbitration Review 2007: China BITs, AsIA PAC. ARB. REv. (2007) (citing the China-Thailand, China-Romania, and China-Sweden BITs as examples, but also noting that the China-Sweden BIT was subsequently amended).

338 See Chinese Model BIT Version I, supra note 336, art. 9(3); Chinese Model BIT Version II, supra note 336, art. 9(3).

339 ICSID Secretariat, Contracting States and Measures Taken by Them for the Purpose of the Convention: Notifications Concerning Classes of Disputes Considered Suitable or Unsuitable for Submission to the Centre, ICSID/8-D at 1 (July 2012), available at $\mathrm{http}: / / \mathrm{icsid}$. worldbank.org/ICSID/FrontServlet?requestType=ICSIDDocRH \&actionVal=ShowDocument\&Measures=True $\&$ language $=$ English. China's notification was made on January 7,1993, pursuant to the ICSID Convention, which allows any contracting state at the time of ratification to provide notice of the classes of disputes it would not consider submitting to the jurisdiction of ICSID. ICSID Convention, supra note 50, art. 25(4).

340 See Draft New Model BIT, § III, in GALLAGHER \& SHAN, supra note 336, at Appendix V (displaying $\S$ III of China's new model BIT draft pertaining to investor-state dispute settlement) (displaying § III of China's new model BIT draft pertaining to investor-state dispute settlement). 
arbitration of "any legal dispute" between an investor and the host state "in connection with an investment" in the host state's territory. ${ }^{341}$ By the late 1990 s, China was already attracting rapidly increasing amounts of inward FDI, notwithstanding the narrow dispute settlement clauses in its early BITs. ${ }^{342}$ However, in 1998 China launched its "going abroad" strategy, a strategy that emphasized the promotion of outward FDI over export trade. ${ }^{343}$ Consequently, by the late 1990s, flows of outward FDI from China were also beginning to increase, and surged dramatically by the mid-2000s. ${ }^{344}$ Thus, one of the factors behind the Chinese government's willingness to liberalize its BIT regime in 1998 was its new policy of promoting OFDI. ${ }^{345}$

Ironically, China's first known investor to file an investment arbitration claim was forced to defend a jurisdictional challenge based on the narrow scope of the dispute settlement provision of the 1994 China-Peru BIT. ${ }^{346}$ In Tza Yap Shum v. Republic of Peru, Mr. Tza Yap Shum, a Chinese investor in a Peruvian fish-based food products company, filed a request for arbitration alleging that the actions of Peru's tax authorities breached several provisions of the China-Peru BIT. ${ }^{347}$ Peru challenged the tribunal's jurisdiction to hear the claim, arguing among other things that the BIT limits consent to investor-state arbitration to disputes over the amount of

341 This clause can be found in the current Chinese Model BIT (Version III). Id. at app. IV. The first BIT concluded under the current model was the 1998 China-Barbados BIT. Id. at $\$ 1.78$.

342 Inward FDI stocks in China doubled from $\$ 101$ billion in 1995 to $\$ 203$ billion in 2001. U.N. Conference on Trade and Dev., Notes, supra note 314. Inward FDI stocks in Hong Kong also almost doubled during the same period (from $\$ 228$ billion to $\$ 419$ billion). Id.

343 Congyan Cai, China-US BIT Negotiations and the Future of Investment Treaty Regime: A Grand Bilateral Bargain with Multilateral Implications, 12(2) J. INT'L ECON. L. 457,459 (2009).

344 OFDI flows from China averaged about $\$ 2.3$ billion annually throughout the 1990 s, and then surged to $\$ 12.3$ billion in $2005, \$ 52$ billion in 2008 , and $\$ 68$ billion in 2010. U.N. Conference on Trade and Dev., Notes, supra note 314.

345 GALlaGHER \& SHAN, supra note 336, at 41.

346 Tza Yap Shum v. Republic of Peru, ICSID Case No. ARB/07/6, Decision on Jurisdiction and Competence, 311, \165 (June 19, 2009).

347 Id. If 30-31. (showing Mr. Tza Yap Shum alleged violations of the expropriation, fair and equitable treatment, and transfers provisions of the BIT). 
compensation for expropriation. ${ }^{348}$ The tribunal issued an interim award upholding its jurisdiction to hear the expropriation claim. ${ }^{349}$ Although it upheld its jurisdiction to hear the expropriation claim, the tribunal dismissed the investor's other claims for lack of jurisdiction, finding that the most-favored nation provision of the BIT could not be read to "override" the narrow scope of the dispute settlement provision. ${ }^{350}$ In July 2011 , the tribunal issued an award on the merits, finding that Peru had breached the expropriation guarantee of the BIT and awarding Mr. Tza Yap Shum $\$ 786,000 .^{351}$ The award was substantially less than the $\$ 25$ million the investor was seeking. ${ }^{352}$

A group of Chinese investors in a Mongolian iron ore mine recently filed another investment arbitration claim, alleging that Mongolia's cancellation of an important license breached the 1991 China-Mongolia BIT. ${ }^{353}$ Although details of this arbitration have not yet been made public, it is quite possible that Mongolia will challenge the tribunal's jurisdiction on similar grounds to those raised by Peru in Tza Yap Shum. The China-Mongolia BIT,

348 Id. I 129. In support of this argument, Peru submitted the witness statement of Chinese law expert Professor An Chen, who stated that the China-Peru BIT, like dozens of BITs concluded during the early 1990s, only allowed for investor-state arbitration where a domestic court had determined that an expropriation had occurred but the amount of compensation owed to the investor remained in dispute. Id. $\mid 131$.

$349 \mathrm{Id}$. If 221. The tribunal reasoned that the phrase "involving the amount of compensation for expropriation" in the BIT should be read as encompassing not only a tribunal's determination of the amount due to the investor but also determining whether an expropriation had taken place. $I d$. $\$ 188$.

350 Id. $\uparrow 220$. Mr. Tza Yap Shum invoked the most-favored nation provision of the BIT, arguing that the benefit of broader dispute settlement provisions extended to investors under Peruvian BITs should also be available to him. Id. ffl 189-91. For a critique of the tribunal's reasoning (but not the outcome) on this issue, see Andrew Newcombe, Another Misapplication of MFN? Tza Yap Shum v. The Republic of Peru, KLUWERARBITRATIONBLOG.COM (Oct. 21, 2009), http://kluwerarbitrationblog.com/blog/ 2009/10/21/another-misapplication-of-mfn-tza-yap-shum-v-the-republic-of-peru/.

351 Luke Eric Peterson \& Jonathan Bonnitcha, New Government in Peru Confronts Recent Arbitration Loss, and New Claims by Foreign Investors in Electricity Transmission, Construction and Port Sectors, Inv. ARB. REP. (Aug. 4, 2011) $\mathrm{http} / / / \mathrm{www}$.iareporter.com/articles/20110805 (subscription required).

$352 \mathrm{Id}$.

353 Luke Eric Peterson, Tribunal Chosen to Hear Ad-Hoc Arbitration by Chinese Mining Investors Against Republic of Mongolia, INV. ARB. ReP. (Nov. 4, 2010) $\mathrm{http}: / /$ www.iareporter.com/articles/20101105_4 (subscription required). 
similar to other early Chinese BITs, contains a narrow dispute settlement clause, limiting consent to investor-state arbitration to disputes involving the amount of compensation for expropriation. ${ }^{354}$

To summarize, China has concluded more BITs and FTAs than almost any other country, and the content of these treaties has liberalized over time, partly in response to increasing quantities of Chinese OFDI. China is also in BIT negotiations with the United States, as discussed below. ${ }^{355}$ The Tza Yap Shum dispute illustrates how Chinese investors in other countries are beginning to invoke the protections of China's BITs.

\section{b. India}

India's industrial policy underwent profound change in the $1990 \mathrm{~s}$ as the government adopted measures to deregulate the economy, liberalize trade, and promote FDI. ${ }^{356}$ Since 1992, the government has progressively relaxed restrictions on outward investment. $^{357}$ One consequence of this policy has been an extraordinary increase in India's OFDI: from around $\$ 2$ billion in 2000 to $\$ 92$ billion in $2010 .^{358}$ Although Indian firms tended to invest in other developing countries in the past, today they increasingly invest in developed countries, as illustrated by Tata Motors's 2008 acquisition of British companies Jaguar and Land Rover. ${ }^{359}$

The Indian government's economic liberalization policy has included what Prabhash Ranjan and Deepak Raju describe as a

354 Agreement Concerning the Encouragement and Reciprocal Protection of Investments, China-Mong., art. 8, Aug. 26, 1991, available at http://www.unctad.org/sections/dite/iia/docs/bits/china_mongolia.pdf (last visited Oct. 8, 2011).

355 See infra Part IV and note 432.

356 Prema-Chandra Athukorala, Outward Foreign Direct Investment from India, 26(2) ASIAN DEv. REv. 125, 129 (2009).

357 Id. at 129-30.

358 See supra Graph 1.

359 See the discussion of Tata Motors in Part I, supra note 24 and accompanying text. The developed country share of approved OFDI by Indian multinational companies increased from $13.9 \%$ during the period before 1990 to $53.8 \%$ in $2002-2006$. Athukorala, supra note 356 , at 135 tbl.2. 
"gigantic" BIT and FTA program. ${ }^{360}$ India has concluded eightytwo BITs $^{361}$ and four FTAs with investment chapters and is in negotiations with many other countries to conclude additional agreements. ${ }^{362}$ Additionally, the terms of these BITs are strongly pro-investor, including most, if not all, of the investment protections described in Part II.A. ${ }^{363}$ India is also in negotiations with the United States to conclude a BIT. ${ }^{364}$ Although negotiations had stalled due to a stalemate within the Obama Administration regarding review of the U.S. Model BIT, ${ }^{365}$ reports suggest that negotiations between the United States and India have resumed with respect to aspects of the BIT that are not likely to change in the model BIT review. ${ }^{366}$

360 Prabhash Ranjan \& Deepak Raju, The Enigma of Enforceability of Investment Treaty Arbitration Awards in India, 6 ASIAN J. COMP. L. 1, 5 (2011). The authors noted that International Investment Agreements (IIAs) "as a generic term, [include] Bilateral Investment Treaties (BITs) [and] investment chapters in Free Trade Agreements (FTAs)." Id. at $1 \mathrm{n} .1$.

361 See U.N. CONFERENCE ON TRADE AND DEV., Total Number of Bilateral Investment Agreements Concluded: India (June 1, 2012), http://unctad.org/Sections/dite_pcbb/docs/bits_india.pdf; see also supra Table 3.

362 See Ranjan \& Raju, supra note 360, at 6-7; see also Prabash Ranjan, Indian Investment Treaty Programme in the Light of Global Experiences, 45 ECON. \& POL. WKLY. 68, 68 (2010) (noting that India is in BIT negotiations with 25 countries in 2010); Gov't of India, Ministry of Finance, Bilateral Investment Promotion and Protection Agreements (BIPA), http://www.finmin.nic.in/bipa/bipa_index.asp?pageid=1 (last visited Oct. 8, 2012).

363 See Ranjan \& Raju, supra note 360 , at 7 (describing Indian BIT protections as "broad," including fair and equitable treatment, most-favored nation treatment, national treatment, guarantees of free transfer of capital, guarantees against direct and indirect expropriation and consent to investor-state arbitration of disputes).

364 See Ambassador Karl F. Inderfurth, Advancing U.S.-India Economic Ties: BIT and Beyond, CTR. FOR STRATEGIC AND INT'L STUD.: U.S.-INDIA INSIGHT (June 2012), http://csis.org/files/publication/120608_WadhwaniChair_USIndiaInsight.pdf (discussing the U.S. goal of supporting bilateral trade and investment opportunities between U.S. and India).

365 See ACIEP, supra note 208.

366 An Obama administration official recently stated that unresolved issues holding up review of the U.S. model BIT will not delay technical BIT talks with India. See U.S., India to Hold Technical BIT Talks Despite Ongoing U.S. Internal Debate, INSIDE U.S. TRADE, Jul. 11, 2011, ๆๆ 1-6; see also Tsui, supra note 208, at 1246 (technical BIT talks to resume with India in August 2011). 


\section{c. Russia}

Russian BIT practice dates back to the Soviet era. ${ }^{367}$ The USSR concluded its first BIT in $1989 .{ }^{368}$ Similar to Chinese practice, some (but not all) of these early treaties were conservative with respect to investor-state dispute settlement, providing for arbitration of only a limited range of matters under the treaty. ${ }^{369}$ During its period of rapid economic liberalization under the Yeltsin regime, Russia concluded numerous BITs containing relatively rigorous investment protections. ${ }^{370}$ After Vladimir Putin was elected Russia's president in 2000, however,

367 Russia assumed the treaty obligations of the USSR upon the USSR's dissolution in 1991. See Rein Mullerson, New Developments in the Former U.S.S.R. and Yugoslavia, 33 VA. J. INT'L L. 299, 305 (1993).

368 Noah Rubins \& Azizjon Nazarov, Investment Treaties and the Russian Federation: Baiting the Bear?, 9 BUS. L. INT'L 100, 102 (2008).

369 See, e.g., Agreement Concerning the Promotion and Reciprocal Protection of Investments (with Protocol), Fed. Republic of Ger.-U.S.S.R., art. 10(1)-(3), June 13, 1989, 1707 U.N.T.S. 194 (limiting investor-state arbitration to disputes over the amount of compensation for nationalization or the investor's right to transfer payments); $c f$. Agreement for the Promotion and Reciprocal Protection of Investments, Can.-U.S.S.R., art. IX(1), Nov. 20, 1989, 1852 U.N.T.S. 215 (providing for investor-state arbitration of any dispute involving a measure taken by the host state affecting the investor's "management, use, enjoyment or disposal" of the investment).

370 of the 71 concluded Russian BITs reported to UNCTAD, over half were concluded between 1992 and 1999. U.N. ConfERENCE ON TRADE AND DEV., Total Number of Bilateral Investment Agreements Concluded: Russian Federation (June 1, 2012), http://unctad.org/Sections/dite_pcbb/docs/bits_russia.pdf [hereinafter UNCTAD Russia BIT List]. For an example of a Russian BIT of this period containing strong investor protections, including a broad investor-state arbitration provision, see Agreement on the Promotion and Reciprocal Protection of Investments, Swed.-Russ., Apr. 19, 1995, http://www.unctad.org/sections/dite/iia/docs/bits/sweden_russia.pdf.

Russia's government adopted a model BIT in 2001 that eliminated investor protections such as fair and equitable treatment, and limited investor-state arbitration to situations where the parties agree to arbitrate post-dispute. Rubins \& Nazarov, supra note 368 , at 104 . However, BITs that Russia subsequently concluded with Thailand and Jordan include a fair and equitable treatment commitment, and broadly provide for investor-state arbitration of disputes. See Agreement on the Promotion on and Mutual Protection of Investments, Russ.-Thai., arts. 2(2)-(3), 9(1)-(2), Oct. 17, 2002, http://www.unctad.org/sections/dite/iia/docs/bits/russia thailand.pdf (limiting fair and equitable treatment obligation to investments that have been "specifically approved" by the competent authority in the host state); Agreement on the Promotion and Mutual Protection of Investments, Jordan-Russ., arts. 3(1), 8(1)-(2), Feb. 13, 2007, http://www.unctad.org/sections/dite/iia/docs/bits/russia_jordan_ru.PDF (in Russian). 
Russia's BIT practice slowed somewhat. ${ }^{371}$ It is also telling that the BITs Russia has concluded since 1999 have predominantly been with other EMEs. ${ }^{372}$

It is possible that the rapid rise in the price of oil during the 2000s, along with Russia's recovery from its 1998 financial crisis, caused Russia's leadership to attach a lower priority to adopting government measures to attract FDI. ${ }^{373}$ Additionally, in 2005, a group of investors in Yukos Oil Company filed massive investment arbitration claims against Russia for breach of the Energy Charter Treaty. ${ }^{374}$ Doubtless the Yukos claims, which if successful could amount to as much as $\$ 100$ billion, ${ }^{375}$ have affected and will affect the Russian government's stance towards BITs. ${ }^{376}$

Nonetheless, at least since the 2008 financial crisis, Russia's government appears to be motivated to integrate with the global economy by concluding its WTO accession negotiations. ${ }^{377}$ The

371 Of the 71 concluded Russian BITs reported to UNCTAD, 22 were concluded after 1999. UNCTAD Russia BIT List, supra note 370.

372 Of the 22 Russian BITs concluded after 1999, all but two were concluded with other EMEs. Id.

373 See Rubins \& Nazarov, supra note 368, at 105 (describing how a Russian official effectively admitted that high natural resource prices and the improvement in Russia's economy were factors behind the government's freeze in concluding new BITs). Similarly, during this period Russia's leaders attached a low priority to concluding pending negotiations to join the WTO, although the government has renewed its accession efforts since the 2008 financial crisis. See John W. Miller, Russia's Membership in World Trade Group Faces Hurdles, WALL ST. J., Feb. 23, 2011, at A9 (describing Russia's reluctance to advocate strongly for membership in the WTO in the past and the country's recognition that it needs to integrate with the global economy).

374 Yukos Universal Ltd. v. Russian Fed'n, Interim Award on Jurisdiction and Admissibility (Perm. Ct. Arb. 2009), http://italaw.com/documents/YULvRussian Federation-InterimAward-30Nov2009.pdf (last visited Oct. 8, 2012). Three Yukos shareholders filed separate requests for arbitration in February 2005: Yukos Universal Ltd., Hulley Enters. Ltd., and Veteran Petroleum, Ltd. Id.

375 Collectively, the three arbitration claims seek compensation of $\$ 100$ billion. Energy Charter Secretariat, Investor-State Dispute Settlement Cases: Yukos Universal Ltd. v. Russ. Fed'n, http://www.encharter.org/index.php?id=213\&L=0\#Yukos (last visited Oct. 8, 2012).

376 In 2009 , the arbitral tribunal upheld its jurisdiction to hear the shareholders' claims. Yukos Universal Ltd. Interim Award, I 397. Although Russia never ratified the Energy Charter Treaty, the tribunal found that the treaty's provisions on provisional application nonetheless bound Russia to arbitrate the investors' claims. Id. ๆๆ 394-98.

377 Miller, supra note 373, at A9. 
recent surge in Russia's OFDI also seems to create incentives for the government to protect the interests of its investors abroad through the conclusion of BITs and FTAs. ${ }^{378}$ One Russian investor, Sergei Paushok, successfully invoked the investor-state arbitration mechanism of the 1995 Russia-Mongolia BIT. ${ }^{379}$ In April 2011, an arbitral tribunal found that Mongolia had breached the fair and equitable treatment guarantee of the BIT by exporting to a foreign account gold that Paushok's company had deposited with the Mongolian Central Bank. ${ }^{380}$ UNCTAD's investor-state dispute settlement database also reports that a Russian investor, Iurii Bogdanov, won an investment arbitration award against Moldova in 2005. ${ }^{381}$

\section{d. Brazil}

As stated, Brazil is unique among significant capital-exporting EMEs for not having in force a single BIT or FTA with an investment chapter. Although Brazil's executive branch concluded fourteen BITs between 1994 and 1999 as part of a broader economic liberalization strategy, ${ }^{382}$ these BITs were never ratified. Faced with strong opposition from certain members of Brazil's National Congress, the treaties were eventually withdrawn from consideration. ${ }^{383}$ Brazil is also in the minority of countries

378 See generally UNCTAD Report 2011, supra note 319, at 9 fig.I.9 (noting Russia's OFDI).

379 Paushok v. Gov't of Mong., Award on Jurisdiction and Liability, at 168 (UNCIT Arb. Trib. Apr. 28, 2011), http://italaw.com/documents/PaushokAward.pdf.

380 Id. If $587-96$. The amount of damages owed to Paushok for breach of the BIT is to be determined in a separate proceeding. $I d$. $\uparrow 700$.

381 UNCTAD, Database of Treaty-Based Investor-State Dispute Settlement Cases (Pending and Concluded), http://unctad.org/iia-dbcases/index.html (last visited Oct. 8, 2012) [hereinafter UNCTAD Investor-State Database].

382 FiLHO, supra note 164, at 3-4; see also UNCTAD, Total Number of Bilateral Investment Agreements: Brazil (June 1, 2012), http://unctad.org/Sections/ dite_pcbb/docs/bits_brazil.pdf.

383 Filho, supra note 164, at 5; see also LeANy Lemos \& Daniela CAMPELlo, THE NON-RATIFICATION OF BILATERAL INVESTMENT TREATIES: A STORY OF CONFLICT IN A LAND OF COOPERATION 19 (Global Leaders Fellows Conference ed., May 2010) (noting that the Brazilian BITs were withdrawn from consideration at the end of President Fernando Henrique Cardoso's term in 2002). Lemos and Campello suggest that Parliament's failure to ratify these BITs is particularly puzzling in light of the concentration of power in Brazil's executive branch; between 1988 (the beginning of Brazil's return to democracy) and 2006, the vast majority of international treaties 
worldwide not party to the ICSID Convention. ${ }^{384}$

There are two reasons to think that Brazil, like India and China, may become more receptive to investment arbitration and BITs over time. First, Brazil's policies towards arbitration have evolved substantially over the past ten or so years. ${ }^{385}$ One aspect of the fourteen concluded BITs that raised the greatest concern with Brazil's legislators was the investor-state dispute settlement mechanism. ${ }^{386}$ Since the late 1990 s, however, Brazil has become a party to the New York Convention. ${ }^{387}$ Although Brazil had finally adopted a modern arbitration law by the mid-1990s, its constitutionality was upheld by Brazil's Supreme Court only in $2001{ }^{388}$ Today, Brazilian companies are by far the most frequent users of arbitration in Latin America: of the 241 disputes brought to ICC arbitration in 2009, over one-third involved either a

submitted to Parliament were ratified, and most of those that were ratified were done relatively quickly. Id. at 4.

384 Interestingly, neither Brazil, India, Russia, nor South Africa is party to the ICSID Convention, although all of these states are party to the New York Convention. Convention on the Recognition and Enforcement of Foreign Arbitral Awards, June 10, 1958,21 U.S.T. 2518,330 U.N.T.S. 38 [hereinafter New York Convention]. What this means is that an investment arbitration award issued against any of these four countries would be enforceable under the New York Convention, which allows at least some leeway for a domestic court to refuse enforcement of the award. Id. art. V (listing limited grounds on which a court may refuse recognition and enforcement of a foreign arbitral award). In contrast, ICSID awards, although subject to annulment, are automatically enforceable within the territory of any ICSID party. See ICSID Convention, supra note 50, art. 54(1) (requiring contracting states to recognize an arbitral award under the Convention as binding and enforceable "as if it were a final judgment of a court of that state").

385 See generally Rafael Villar Gagliardi \& Cesar Rossi Machado, Highlights of Arbitration Developments in Brazil, 16 IBA ARB. NEws 112 (March 2011) (noting that the "use of arbitration" has grown in Brazil in recent years).

386 FILHO, supra note 164, at 6; see also Jean Kalicki \& Suzana Medeiros, Investment Arbitration in Brazil: Revisiting Brazil's Traditional Reluctance Towards ICSID, BITs, and Investor-State Arbitration, 14 REVISTA DE ARBITRAGEM E MEDIAÇÃO $57,68(2007)$.

387 Brazil became a party to the Convention in 2002. UNCITRAL, Status 1958Convention on the Recognition and Enforcement of Foreign Arbitral Awards, http://www.uncitral.org/uncitral/en/uncitral_texts/arbitration/NYConvention_status.html (last visited Oct. 8, 2012).

388 Arnoldo Wald \& Jean Kalicki, The Settlement of Disputes Between the Public Administration and Private Companies by Arbitration under Brazilian Law, 26 ARB. INT'L 556, 557 (2009). 
Brazilian claimant or respondent. ${ }^{389}$ Finally, since 2005, arbitration can even be utilized to resolve disputes between private investors and Brazilian state agencies so long as the arbitration is conducted in Brazil, in the Portuguese language, and in accordance with Brazilian law. ${ }^{390}$

Second, Brazil is becoming a significant exporter as well as importer of FDI. ${ }^{391}$ One factor behind Brazil's failure to ratify the fourteen BITs concluded in the 1990s was the lack of a sufficiently strong domestic constituency lobbying in favor of ratification. ${ }^{392}$ As a result, individuals within the legislature with a strong bias against BITs successfully organized against them. ${ }^{393}$ Some members of Parliament reasoned that Brazil would be able to attract FDI without concluding BITs. ${ }^{394}$

Although it is certainly true that Brazil has been able to attract FDI without BITs in force, ${ }^{395}$ Brazilian companies are now among the world's most significant exporters of FDI. Brazil's OFDI stocks more than tripled between 2000 and 2010. ${ }^{396}$ While this increase is less dramatic than Russia's or India's, it is still significant. Companies such as Petrobras (petroleum), Vale (mining), Gerdau (metal products), and Odebrecht (construction) are part of a group of Brazilian companies that can now be

389 Brazilian parties were involved in 86 of the 241 disputes involving Latin America and the Caribbean brought to ICC arbitration in 2009. ICC INT'L COURT OF ARBitration, 2009 STATISTICAL REPort 7 (2010). After Brazil, the next most frequent user of ICC arbitration for Latin America and the Caribbean was the British Virgin Islands, whose parties were involved in twenty-eight disputes in 2009. Id. During 1998, in contrast, Brazilian parties were involved in only five ICC arbitrations. ICC INT'L Court of Arbitration, 1998 Statistical Report 5 (1999).

390 Wald \& Kalicki, supra note 388, at 573 (discussing Brazil's Public-Private Partnership Law of 2004 and a 2005 amendment to Brazil's Concessions Law allowing for the use of arbitration to resolve disputes).

391 UNCTAD Report 2011, supra note 319, at 5, 7.

392 LEMOS \& CAMPELLo, supra note 383, at 32-33.

393 Id. at 33. In contrast, Brazilian business interests did lobby for the ratification of double-taxation treaties, of which 24 were successfully approved by Parliament. $l d$. at 32-33.

394 FILHO, supra note 164, at 5.

395 In 2010, Brazil ranked fifth in the world in terms of inward FDI flows. UNCTAD Report 2011, supra note 319, at 4 fig.I.4.

396 Between 2000 and 2010, Brazil's OFDI stock increased from $\$ 52$ billion to $\$ 181$ billion. See supra Graph 1. 
characterized as multinationals. ${ }^{397}$ Some of these investors have had to resolve disputes with foreign governments. For example, the Brazilian construction firm Odebrecht contracted to build a hydroelectric dam in central Ecuador, but the company encountered structural problems during the construction of the dam. ${ }^{398}$ In 2008, Rafael Correa's government terminated four existing contracts and expelled Odebrecht from the country. ${ }^{399}$ In 2009 , Ecuador filed an arbitration claim against Odebrecht before a domestic tribunal, seeking $\$ 250$ million in damages. ${ }^{400}$ Similarly, in 2004, Petrobras entered into a concession with the Bolivian government to develop natural gas fields only to have its investment nationalized when Evo Morales came to power in 2006. ${ }^{401}$ Although the Petrobras dispute with Bolivia was ultimately resolved diplomatically, Petrobras nonetheless structured its investment so as to take advantage of Bolivia's BIT

397 John Prideaux, A Special Report on Business and Finance in Brazil: Arrivals and Departures, ECONOMIST (Nov. 12, 2009), www.economist.com/node/14829517; see also U.N. Conference on Trade and Dev., World Investment Report 2011: Country Fact Sheet: Brazil 2 (2011), http://www.unctad.org/sections/dite_dir/docs/wirl1_fs_br_en.pdf (listing Petrobras, Vale, and Gerdau among the world's top 100 non-financial transnational corporations from developing countries in 2010 , as ranked by foreign assets).

398 See generally Jean Friedman-Rudovsky, The Bully from Brazil, FoREIGN POL'Y (July 20, 2012), http://www.foreignpolicy.com/articles/2012/07/20/ the_bully_from_brazil?page=full (including Odebrecht's dam project as an example of the Brazilian company's large scale projects in Latin America).

399 C.J. Schexnayder, Big Brazilian Firm Under Fire in Ecuador and Venezuela, ENGINEERING NEWS REC., Nov. 17, 2008, at 14, available at http://enr.construction.com/news/finance/archives/081112a.asp.

400 Equador entra com pedido de arbitragen contra Odebrecht, GLoво.COM (May 5, 2009) http://gl.globo.com/Noticias/Economia_Negocios/0,,MUL1 108926-9356,00EQUADOR+ENTRA+COM+PEDIDO+DE+ARBITRAGEM+CONTRA+ODEBRECH T.html (last visited Oct. 11, 2012).

401 Paulo Prada, Bolivian [sic] Nationalizes the Oil and Gas Sector, N.Y. TiMES, May 2, 2006, at A9. With over $\$ 1$ billion invested, Petrobras was the largest foreign investor affected by the nationalization. $I d$.

Petrobras was also a target of the Ecuador government's 2007 decision to "renegotiate" the terms of participation contracts it had concluded with foreign investors to develop oil reserves. See generally Aldo Musacchio, Lena G. Goldberg \& Ricardo Reisen de Pinho, Petrobras in Ecuador (Harvard Business School 2009) (examining as a case study the 2007 essential takeover of Petrobas's production by the Ecuadorian government). 
with the Netherlands. ${ }^{402}$ In other words, as the community of Brazil's outward foreign investors grows larger and more motivated to lobby for investment protections, political conditions may become more favorable for Brazil to conclude and ratify BITs or FTAs with investment chapters. ${ }^{403}$

In 2007, the Council of Ministers of Brazil's Chamber of Foreign Trade (CAMEX) approved guidelines for the negotiation of certain investment protection agreements, including the negotiation of FTAs with investment chapters. ${ }^{404}$ Although this has not yet led to Brazil's conclusion of any agreements, the government's inaction may be attributable to the fact that it has been preoccupied with the election and transfer of power to Dilma Rousseff, who was inaugurated as Brazil's president in January $2011^{405}$

\section{e. Implications}

Although practices have varied, the trend among significant capital-exporting EMEs, especially India and China, has been to conclude increasing numbers of BITs and FTAs with investment chapters. $^{406}$ This section briefly considers some implications of this trend, including the possible impact of EMEs on global BIT practice.

402 Kalicki \& Mederios, supra note 386, at 440.

403 See Lemos \& CAMPEllo, supra note 383, at 36 (suggesting that the recent emergence of Brazilian multinationals creates a new constituency favoring investment protection, and may facilitate the future ratification of Brazilian BITs).

404 Id. at 36-37; Luke Eric Peterson \& Ana Carolina e Simões e Silva, Brazil Mandated to Pursue Limited Range of Investment Protection Standards, INV. ARB. REP. (Sept. 8, 2008), http://www.iareporter.com/articles/20091001_35 (subscription required).

405 See Raymond Colitt, Brazil's Rousseff Starts Market-Friendly Transition, REUTERS (Nov. 1, 2010), http://www.reuters.com/article/2010/11/01/us-brazil-electionidUSTRE69S29F20101101 (noting the recent election and describing the transition into power of President Rousseff); Brian Winter, Taking Brazil's Helm, Rousseff Nods to Wall Street, REUTERS (Jan. 3, 2011), http://www.reuters.com/article/2011/01/03/brazilrousseff-idUSN0317199420110103 (discussing Rouseff's priorities in January 2011).

406 See generally U.N. Conference on Trade and Dev., South-South Investment Agreements Proliferating, 1 IIA MONITOR at 1 (2005) [hereinafter South-South Investment Agreements], available at http://www.unctad.org/en/docs/ webiteiit20061_en.pdf (discussing that investment agreements between developing countries have increased substantially "in number and geographical coverage" in the last ten years). 
Not only have EMEs increased their BIT practice, but they are more frequently concluding BITs and FTAs with each other. ${ }^{407}$ As noted above, Russia's recent BIT practice has been almost exclusively with other EMEs. ${ }^{408}$ The number of BITs concluded between developing countries increased fourteen-fold between 1990 and 2004. ${ }^{409}$ As of the end of 2006, 680 (or about twentyseven percent) of the 2500 BITs that had been concluded were concluded between developing countries. ${ }^{410}$ Lauge Poulsen defines "South-South" BITs as BITs concluded between EMEs, a broader definition that includes transition countries as well as developing countries. ${ }^{411}$ By this measure, Poulsen estimates that South-South BITs account for forty percent of all BITs. ${ }^{412}$ A question to consider is whether South-South BITs are substantively any different from BITs concluded with or between developed economies.

A recent UNCTAD study found that, although there were "few specifically South-South features" noticeable in the body of SouthSouth BITs, the agreements tend to focus on economic development concerns more than other BITs. ${ }^{43}$ For example, South-South BITs are less likely to guarantee market access to foreign investment, focusing instead on protections of existing investment, and are less likely to expressly prohibit performance requirements. ${ }^{414}$ Poulsen conducted an empirical analysis of over 300 BITs to determine whether the national treatment and transfer guarantees of BITs differ when concluded between EMEs. ${ }^{415} \mathrm{He}$ found that South-South BITs are more likely than North-South BITs to: (i) restrict or exclude the national treatment obligation guarantee; and (ii) include exceptions to the transfer of payments

407 See id. at 1.

408 UNCTAD Russia BIT List, supra note 370.

409 The number of BITs concluded between developing countries increased from 44 in 1990 to 653 in 2004. South-South Investment Agreements, supra note 406, at 1.

410 Echandi, supra note 53, at 7.

411 Lauge Skovgaard Poulsen, The Significance of South-South BITs for the International Investment Regime: A Quantitative Analysis, 30 Nw. J. INT'L L. \& Bus. 101,101 n.2 (2010).

412 Id. at 101.

413 UNCTAD, Recent Developments, supra note 335, at 2.

$414 \mathrm{Id}$

415 Poulsen, supra note 411 , at 112-13. 
guarantee. ${ }^{416}$ These differences, however, are undercut by the existence of broad "most-favored nation" (MFN) clauses, which could allow investors to benefit from the more generous protections contained in other treaties. ${ }^{417}$ To summarize, there is at least some evidence to suggest that over time, the growing body of BITs and FTAs concluded between EMEs may provide a moderating influence on the substance of the international investment protection regime.

Similarly, it will be interesting to see how the institution of investment arbitration and the growing body of investment arbitration decisions are affected, if at all, when investors from EMEs are bringing claims. Tza Yap Shum ${ }^{418}$ and Paushok ${ }^{419}$ are examples of claims brought to investment arbitration by investors from EMEs (China and Russia, respectively). UNCTAD's investor-state dispute settlement database lists forty-nine disputes involving claimants from EMEs. ${ }^{420}$ The vast majority of these disputes were initiated since $2003 .{ }^{421}$ Regardless of whether the nationality of the investor has had any impact on the tribunal's decision in these cases (most likely it has not), it is nonetheless significant that EME investors are bringing investment arbitration claims. The fact that institutions such as ICSID increasingly adjudicate claims brought by EME investors arguably enhances the legitimacy of the institution. Similarly, the fact that EME investors are adjudicating BIT claims likely has affected and will continue to affect attitudes within EME governments towards BITs and investment arbitration, just as U.S. attitudes towards investment arbitration shifted when the United States found itself on the respondent side of NAFTA Chapter 11 disputes. ${ }^{422}$

$416 \mathrm{Id}$. at 118,123 (noting that South-South BITs are two to three times more likely to limit or exclude national treatment provisions, and three to four times more likely to include restrictions on transfer clauses, than North-South BITs.)

417 Id. at $128-29$.

418 Tza Yap Shum v. Republic of Peru, ICSID Case No. ARB/07/6, Decision on Jurisdiction and Competence (June 19, 2009).

419 Paushok v. Gov't of Mong., Award on Jurisdiction and Liability (UNCIT Arb. Trib. Apr. 28, 2011), http://italaw.com/documents/PaushokAward.pdf.

420 UNCTAD Investor-State Database, supra note 381.

421 Forty-three of the 49 claims have been brought since 2003. Id.

422 Defending against investor claims has also prompted the U.S. State Department to approach the international law of investment protection in new ways. For example, 
Finally, it remains to be seen whether pending U.S. BIT negotiations with India and China will be successful and, if so, how the content of these BITs will compare with the 2004 Model BIT. Negotiations with both countries stalled in 2009 pending the Obama Administration's review of the U.S. Model BIT, ${ }^{423}$ although there are reports that BIT negotiations with India have resumed. ${ }^{424}$ India's general approach to BITs may be even more investor protection-oriented than that of the United States. ${ }^{425}$ As for China, there remain important differences between U.S. and Chinese BIT practices. Most importantly, the U.S. Model BIT grants investors national treatment with respect to the "establishment, acquisition, expansion, management, conduct, operation, and sale or other disposition of investments." ${ }^{426}$ In contrast, Chinese BITs only grant investors protection postestablishment, and only "in accordance with its laws and regulations." ${ }^{427}$ In other words, Chinese BITs, like those of other EMEs, either limit or do not afford national treatment to foreign investors. ${ }^{428}$ At the same time, however, recent Chinese BITs have borrowed innovations from the U.S. 2004 Model BIT with respect to other core BIT protections. The 2006 China-India BIT defines indirect expropriation using language very similar to Annex B of the 2004 Model BIT. ${ }^{429}$ The fair and equitable treatment provision of the 2008 China-Mexico BIT borrows liberally from Article 5 of

only after defending against NAFTA Chapter 11 claims such as Loewen did the State Department begin emphasizing the opinio juris requirement in defining customary international law. VANDEVELDE, INVESTMENT AGREEMENTS, supra note 12, at 65-66.

423 Tsui, supra note 208, at 1246; Expert: China's Push to Invest Abroad May Aid Effort to Discipline SOEs, INSIDE U.S. TRADE, | 1, Jul. 21, 2011.

424 See supra note 366 , and accompanying text.

425 As discussed, India's BITs provide rigorous protections to foreign investors. See Ranjan \& Raju, supra note 360, at 7; see also Prabhash Ranjan, Tread Cautiously on Bilateral Investment Treaties, HINDU Bus. LINE (Nov. 25, 2009), http://www.thehindubusinessline.com/todays-paper/tp-opinion/article 1070187.ece (describing Indian BITs as being drafted solely from the perspective of investment protection, and noting the absence in the preamble to Indian BITs of reference to other sovereign objectives).

4262004 Model BIT, supra note 194, art. 3(1).

427 Cai, supra note 343 , at 470 (internal citations omitted).

428 See Poulsen, supra note 411 , and accompanying text.

429 Cai, supra note 343, at 478 n.120; see also 2004 Model BIT, supra note 194, at Annex B. 
the 2004 Model BIT. ${ }^{430}$ Finally, the 2008 China-New Zealand FTA's investor-state dispute settlement provision incorporates several innovations from the 2004 Model BIT. ${ }^{431}$ In dramatic contrast to the $1980 \mathrm{~s}$, when U.S. and Chinese BIT practices stood at two ends of a spectrum, ${ }^{432}$ their practices have converged significantly over the past two decades.

Similarly, since 2005, China has been in negotiations with Australia over an FTA that includes an investment chapter. ${ }^{433}$ The issue of investor-state dispute settlement may prove to be particularly difficult in these negotiations, since the Australian government released a statement in 2011 announcing that it will discontinue including investor-state dispute resolution procedures in trade agreements. ${ }^{434}$ Jürgen Kurtz suggests that, in light of the "massive" amounts of Chinese FDI invested in Australia and legitimate concerns regarding Australia's past treatment of Chinese investors, it is quite possible that China will insist that any FTA between them include a provision for investor-state dispute settlement. ${ }^{435}$ It is indeed ironic that the country that is most likely to insist on a treaty commitment to arbitrate investor-state disputes is not Australia, but China.

\section{IV.Conclusion}

Greece, in an effort to conclude the largest debt restructuring in history, recently enacted legislation that retroactively inserts collective action clauses into debt instruments governed by Greek law. ${ }^{436}$ If Greece invokes the collective action clauses in order to

430 Cai, supra note 343, at 469 n.58; see also 2004 Model BIT, supra note 194, art.

5 . Note that the treaties' respective definitions of customary international law differ.

431 Id. at 481.

432 When the United States and China engaged in BIT negotiations during the 1980 s, the two sides "disagreed on nearly all critical issues," and talks were suspended in 1988. Id. at 486-87.

433 See Jürgen Kurtz, The Australian Trade Policy Statement on Investor-State Dispute Settlement, 15(22) ASIL INSIGHTS (Aug. 2, 2011), http://www.asil.org/insights 1 10802.cfm.

434 Id. (quoting Gillard Government Trade Policy Statement: Trading Our Way to More Jobs and Prosperity, 14 Aust. Gov't, Dep't of Foreign Aff. \& Trade (Apr. 2011), http://www.dfat.gov.au/publications/trade/trading-our-way-to-more-jobs-andprosperity.html).

$435 \mathrm{Id}$.

436 Matina Stevis, Greek Deal Looks Good To Go, WALl ST. J. (Mar. 6, 2012, 
conclude the restructuring, it is quite possible that creditors adversely affected by such action may allege that Greece has violated its BIT obligations. ${ }^{437}$ However, of the thirty-nine BITs Greece currently has in force, all but two were concluded with either EMEs or formerly Socialist countries. ${ }^{438}$ It is likely that when concluding these treaties, the Greek government did not anticipate that it might find itself defending against investor claims.

As the Greek example illustrates, although the international investment regime used to be characterized as manifesting an "unbalanced" relationship between North and South, this characterization no longer reflects reality. ${ }^{439}$ With the relatively recent and dramatic growth in economic power of the BRICs and other EMEs, the line between capital-importing and capitalexporting countries continues to blur. As a consequence, the dynamics of BIT negotiation have become more complex. Ever since it began defending against arbitration claims brought by Canadian investors under NAFTA Chapter 11, the United States no longer negotiates BITs with the sole objective of protecting its own investors. ${ }^{440}$ These new dynamics should continue to have a moderating influence on the content of new BITs and FTA investment chapters.

Although these dynamics have affected and will affect the

11:54 A.M.), http://blogs.wsj.com/brussels/2012/03/06/greek-deal-looks-good-to-go. A collective action clause allows for modification to key payment terms in a debt instrument with only a supermajority vote. See generally Lee C. Buchheit \& G. Mitu Gulati, Sovereign Bonds and the Collective Will, 51 EMORY L.J. 1317 (2002) (discussing the use and characteristics of English majority action clauses).

437 See, e.g., Daniella Strik, Proposed Greek Collective Action Clauses Law May Trigger Its International Law Obligations, KLUWER LAW INT'L, http://kluwer.practicesource.com/blog/2012/proposed-greek-collective-action-clauseslaw-may-trigger-its-international-law-obligations (last visited Oct. 8, 2012) (discussing the impact of collective action clauses on Greece's existing BIT agreements).

438 U.N. Conference on Trade and Dev., Total Number of Bilateral Investment Agreements Concluded: Greece (June 1, 2012), http://unctad.org/ Sections/dite_pcbb/docs/bits_greece.pdf. The list includes a 1963 BIT concluded with Germany, a significant capital-exporter and home to significant creditors of Greece. Id. The remaining developed countries on the list are Bulgaria, Cyprus, Czech Republic, Estonia, Hungary, Latvia, Lithuania, Poland, Romania, Slovakia, and Slovenia. Id.

439 Echandi, supra note 53, at 5-6; see also Alvarez, supra note 19, at 16.

440 See Kenneth Vandevelde, Model Bilateral Investment Treaties: The Way Forward, 18 SW J. INT'L LAW 307, 309-310 (2011). 
content of future investment protection agreements, much of the investment protection regime is based on the 1857 BITs that were concluded during the 1990 s or earlier. ${ }^{41}$ Most BITs are "sticky," meaning they generally remain in effect for a ten- or fifteen-year term, and subsequently may remain in effect indefinitely unless one of the parties provides written notice of termination. ${ }^{442}$ Even if a BIT is terminated or renegotiated after its term expires, the BIT's protections typically will remain in effect with respect to existing investments for an additional period. ${ }^{443}$ Even as BIT practice evolves, previous generations of treaties will remain in effect for some time.

As for the United States, it is increasingly likely to find itself in the position of host to foreign investors that enjoy protections under BITs and FTA investment chapters. Within the past decade, the United States concluded FTAs with Singapore and Korea, two of the world's most significant EME capital exporters. ${ }^{444}$ If the pending Trans-Pacific Partnership negotiations are successful, the United States could end up party to a multilateral investment protection agreement with eight or more countries, including capital exporters Australia, Singapore and Malaysia. ${ }^{445}$ Most

441 UNCTAD, Quantitative Data, supra note 65, tbl.1.

442 See, e.g., U.S.-Arg BIT, supra note 38, arts. XIV(1)-(2) (providing for an initial 10 -year term; subsequently, treaty will remain in force indefinitely until either party provides one-year's written notice of termination); see also SALACUSE, supra note 11, at 351.

443 See, e.g., US-Arg. BIT, supra note 38, arts. XIV(1)-(2) (providing that upon termination, treaty will remain in effect for an additional 10-year period with respect to existing investments); see also SALACUSE, LAW OF INVESTMENT TREATIES supra note 11 , at 351-52 (stating that most "continuing effects" clauses are effective for an additional 10,15 or 20 years).

444 Singapore FTA, Office of the U.S. Trade Representative, $\mathrm{http} / / / \mathrm{www}$. ustr.gov/trade-agreements/free-trade-agreements/singapore-fta (last visited Oct. 8, 2012); U.S. Korea Free Trade Agreement, Office of the U.S. Trade Representative, http://www.ustr.gov/trade-agreements/free-trade-agreements/korus-fta (last visited Oct. 8, 2012).

445 Gantz, Trans-Pacific Partnership Negotiations, supra note 208. Canada, Mexico, and Japan may join the negotiations as well. Peter Menyasz, Daniel Pruzin \& Amy Tsui, Canada, Mexico Invited to Join TPP Talks, Expected to Enter Negotiations in Early Fall, 29 BNA INT'L TRADE REP. 1004 (Jun. 21, 2012).

Although the negotiations are ongoing, the Trans-Pacific Partnership most likely will not be concluded until 2013 or later. Gantz, Trans-Pacific Partnership Negotiations, supra note 208. Additionally, in light of Australia's recent Trade Policy 
significantly, the United States may conclude BITs with China and India in the not-so-distant future. Although differences remain, the respective negotiating positions of the United States versus India and China with respect to investment protection are significantly closer today than one might have imagined just a decade ago.

Statement, see Kurtz, supra note 433 , it is quite possible that Australia will seek to exclude investor-state dispute settlement from the agreement, at least with respect to its own obligations. 
